IFC Conference on external statistics "Bridging measurement challenges and analytical needs of external statistics: evolution or revolution?", co-organised with the Bank of Portugal (BoP) and the European Central Bank (ECB)

17-18 February 2020, Lisbon, Portugal

\title{
What value added in the trade balances of euro area financial centres? ${ }^{1}$
}

\author{
Virginia Di Nino and Anna Ekstam,
}

\section{European Central Bank}

1 This paper and presentation were prepared for the meeting. The views expressed are those of the authors and do not necessarily reflect the views of the BIS, IFC, BoP, ECB or the central banks and other institutions represented at the meeting. 


\title{
What value added in the trade balances of euro area financial centres?*
}

\author{
Virginia di Nino ${ }^{\dagger}$ \\ European Central Bank
}

\author{
Anna Ekstam \\ European Central Bank
}

August 12, 2020

\begin{abstract}
Beside large capital flows, euro area financial centres feature important and growing trade surpluses. We investigate the composition of their gross trade flows and disentangle (i) domestic and foreign production content that is (ii) directly traded with final absorbing economies or embedded in intermediates that are carried to final destination by partner countries. This accounting exercise uncovers that foreign production transiting through their borders account for most of the surpluses of financial centres but also that the net surplus in domestic value added traded directly with final consumers is twice as large as in other euro area economies. MNEs allocate to financial centres the value created globally, they do through transfer pricing practices which undermine the correct representation of the external position of these countries with a bearing also on the external position of the euro area; their participation in production chains also appears oddly large. When we replace the official trade statistics with predictions based on the gravity law of trade, the surpluses of main euro area financial centres disappear.
\end{abstract}

Keywords: financial centres, profit shifting, trade balance, domestic and foreign, value added

JEL-Classification: F14, F23, F40

${ }^{*}$ We would like to thank Ettore Dorrucci for guidance and support, participants at the ECB DG-E internal seminar and at the IFC Conference on external statistics "Bridging measurement challenges and analytical needs of external statistics: evolution or revolution?" for comments and suggestions. The views expressed in the paper are those of the authors and do not necessarily reflect those of the ECB or of the ESCB.

${ }^{\dagger}$ Correspondence address: European Central Bank, 60311 Frankfurt am Main, Germany; E-mail address: virginia.di_nino@ecb.europa.eu 


\section{Non-technical Summary}

The role of financial centres as hub of global financing, financial risk sharing and international capital movements makes the size of the financial flows transiting through their balance of payments magnitudes larger than their domestic economy. In the course of the past decade their trade flows have also expanded enormously, in a few cases beyond any economically reasonable number for the size of their economy. Furthermore since exports grew constantly more than imports, their trade surpluses rapidly piled up.

On paper, this condition may indicate the presence of macroeconomic imbalances while in practice it also reflects MNEs' global operations rather than domestic disequilibria. Financial holdings and specialised subsidiaries of multinationals (MNEs) are often located in financial centres that offer favourable treatment to profit taxation and the euro area is home of several globally important ones. For these reasons the euro area statistics suffer potentially more than other regions from distortions due to MNE operations, a side effect of globalisation.

Some recent works provide first measurements of the base erosion and profit shifting (BEPS) size globally (see Bolwijn, Casella and Rigo (2018) and Tørsløv, Wier and Zucman (2018)). This paper contributes to the literature on MNEs activity in financial centres with a novel view on their external imbalances from a value added perspective. Our analysis sheds light on additional aspects of profit shifting practices.

The trade balance of euro area countries is broken down by its value added content. In particular, we separate the value contained in foreign trade transactions into the part that (i) the exporting country itself and (ii) its partner economies have produced and exported, either (iii) directly to final consumer or (iv) to intermediate importers that, after further processing, re-export elsewhere.

Our approach identifies what components of the trade balance are most contaminated by MNEs operations and in which direction.

The bilateral break-down highlights that in order to book value in financial centres, MNEs inflate the value of domestic production exported by financial centres, possibly overpricing tasks performed there. These transfer pricing practices underpin the contribution of domestic production for final absorption in net trade balance that in financial centres is twice as large as in other euro area economies.

Moreover, the convenience of such practices is maximised when operated on the exfactory price. This explains why financial centres act as transit for final (or almost final) production of other economies, their net trade in foreign value added absorbed by direct importer is atypically large. Finally our decomposition highlights large deficits in domestic production that is subject to further processing elsewhere; imports from original producers for further processing are way bigger than the value of the production they export for further processing. 
All these operations which are likely to conceal transfer pricing practices, involve at least the crossing of three countries and are therefore classified in the literature as global value chain (GVC) trade. Their GVC participation index is the highest in the world and financial centres appear as the most downstream positioned group of countries.

We find that financial centres are conduits economies of other's production as much as they are of financial transactions.

We also suggest a correction methodology based on trade gravity estimations and encompassing indirect exports and GVC trade, that allows to recompute trade balances in financial centres as predicted by gravity. The largest correction is performed on the domestic production entering global value chains but directly traded with final consumers; this component especially affected profit shifting practices as it pertains the value booked in financial centres. As a results of our corrections the aggregate trade balance of the euro area financial centres shrinks very substantially and remain stable over time. According to our methodology profit shifted to Luxembourg, Ireland, Belgium and the Netherlands would amount to $\$ 170$ billion in 2014, not far from the $\$ 220$ billion found by Bolwijn et al. (2018) for the advanced economies. 


\section{Introduction}

Financial centres foster international capital movements, enhance access to global financing, favour risk sharing across economic agents. This typically makes the size of the financial flows transiting in their balance of payments $(\mathrm{BoP})$ magnitudes larger than their domestic economy. In the course of the past decade their trade flows have also expanded enormously, in a few cases beyond any economically reasonable number for the size of their economy. Furthermore since exports grew constantly more than imports, their trade surpluses rapidly piled up.

On paper, this condition may indicate the presence of macroeconomic imbalances, in practice it reflects MNEs' global operations rather than domestic disequilibria. Activity of global companies reverberate across the external account of hosting countries and in particular on their external balances, leaving footprints in several macro statistics. Financial holdings and specialised subsidiaries of multinationals (MNEs) are often located in financial centres and the euro area is home of several globally important ones. For these reasons the euro area statistics suffer potentially more than other regions from distortions due to MNE operations, a side effect of globalisation.

Several works point out that MNEs pursue tax-optimisation on global scale by shifting value (profits) in financial centres where they receive favourable fiscal treatments and identify transfer pricing and licensing as the dominant channels (see Dowd, Landefeld and Moore 2017; Flaaen et al. 2017; Dharmapala 2019).

Some studies investigate the effects of profit shifting on macro conditions in home countries of headquarters. Overesch (2009) finds that the size of multinationals' real investments in a high-tax country is positively affected by a lower taxation of shifted profits. Guvenen et al. (2017) show that, over the past 25 years, profit shifting has subtracted each year between $0.1 \%$ and $0.25 \%$ growth to the US aggregate productivity, with strongest effects in RD-intensive industries.

The debate about global firms tax strategies has received increasing space in the news and captured policymakers attention as crawling capital taxation and rising labor taxburden led to rising inequality in advanced economies. However authorities face several challenges in finding silver bullet evidence of MNEs misbehaviour due to the lack of micro statistics, difficulties in pricing ICT services and royalties and to the complex schemes, involving transactions going through several jurisdictions, engineered by MNEs to escape corporate taxation.

Recent work provides first measurements of the base erosion and profit shifting (BEPS) size; globally, one estimation is obtained measuring yield differentials on foreign investments across countries and considering evidence of it the premia obtained by companies on investments in financial centres. Alvaredo et al. 2018 link the large current account surplus in low-tax jurisdictions to the favourable corporate taxation and attempt a first correction 
of official BoP statistics based on mirror statistics and micro information.

This paper contributes to the literature on MNEs activity in financial centres with a novel view on their external imbalances from a value added perspective and sheds light on additional aspects of profit shifting practices. In particular it discusses how BEPS practices lead to a misrepresentation of positioning and participation of financial centres in global value chains (GVCs). As mentioned, moving profits implies an allocation of value produced globally to specific countries. This has repercussions on the estimated productivity, on perceived comparative advantages and aggregate production structure of financial centres. Our approach identifies what components of the trade balance are most contaminated by MNEs operations and in which direction. We also suggest a correction methodology based on the gravity law of trade that allows to recompute trade balances in financial centres as predicted by gravity.

The trade balance of euro area countries is broken down by its value added content. In particular, we separate the value contained in foreign trade transactions into the part that (i) the exporting country itself and (ii) its partner economies have produced and exported, either (iii) directly to final consumer or (iv) to intermediate importers that, after further processing, re-export elsewhere. We then compare similar decomposition across countries and unveil that main euro area financial centres (namely the Netherlands, Ireland, Luxembourg and Belgium) share a strikingly similar type of trade balance decomposition, which is not traceable elsewhere.

Some country pairs relationships are more concerned than others by MNEs activity, some components of the trade balance are more affected by global operations than others.

The bilateral break-down highlights that certain peculiarities are common exclusively in bilateral transactions concerning financial and non-financial centres; in other words low and high taxation jurisdictions. Bilateral flows are not all equally distressed by MNEs strategies and we trace back differences across countries to the extent that external statistics are plagued with global operations of MNEs.

In order to book value in financial centres, MNEs inflate the value of domestic production exported by financial centres, possibly overpricing tasks performed there. These transfer pricing practices underpin the contribution of domestic production for final absorption in net trade balance that in financial centres is the twice as large as in other euro area economies; we refer to this component of the trade balance as $D V A-D I R$ in the text.

Moreover the convenience of such practices is maximised when operated on the exfactory price. This explains why financial centres act as transit for final (or almost final) production of other economies, their net trade in foreign value added absorbed by direct importer is atypically large (we refer to it in the text as $F V A-D I R$ ). Finally our decomposition highlights large deficits in domestic production that is subject to further processing elsewhere; import from original producers for further processing is way bigger than the value of the production they export for further processing (the term is labelled as $D V A-G V C$ 
in the paper). Besides, all these operations which are likely to conceal transfer pricing practices, involve at least the crossing of three countries and are therefore considered by practitioners as supply chain trade. Their GVC participation index is the highest in the world and financial centres appear as the most downstream positioned group of countries.

A large and positive trade balance held in foreign production and a negative trade balance in domestic production traded abroad suggest a "in chain" positioning close to final consumers, relative to their trading partners.

In conclusion, financial centres are conduits economies for real transactions as much as they are of financial transactions; just a very small amount of foreign trade booked in their balance of payments is for domestic absorption.

In this paper we take up the challenge to correct official trade flows statistics of financial centres for the footprints left by MNEs. We do so by resorting to predictions of an augmented gravity model of bilateral gross exports, domestic value added exported to final consumers, and domestic value added exported through intermediary countries indirectly to final consumers. The foreign value added exported via financial centres is obtained as the difference between predicted gross exports and predicted exported domestic value added. The magnitude of global value shifted to euro area financial centres is the difference between official and predicted trade balances. Similarly we correct GVC participation and location measures.

The aggregate trade balance of financial centres in our predictions shrinks substantially and stabilise. In particular the estimation downsizes gross exports, domestic and foreign production content substantially; the largest correction is performed on the domestic production entering global value chains but directly traded with final consumers; this component is likely to be the most affected by profit shifting practices as it pertains the value booked in financial centres. Profit shifted to Luxembourg, Ireland, Belgium and the Netherlands is found to amount all together to $\$ 170$ billion in 2014 , which is comparable with previous evaluations in the BEPS literature. Our strategy may not be sufficient to fully correct for BEPS practices as GVC participation of financial centres is still exceptionally high, although the positioning is definitely less downstream.

The paper introduces our novel decomposition of trade balances by the type of value added in section 2 and compares them across types of countries (financial centres versus other euro area main economies, and other large economies like US, UK and China); it reviews GVC measures in section 3. Section 4 provides details on gravity specification augmented to control for the structure of foreign trade of the bilateral importers and section 5 discusses estimates and compute new trade balances as well as GVC measures based on predicted trade flows. We perform a series of checks on the validity of the methodology and on our findings robustness in section 6 . Section 7 concludes with a review of main takeaways. 


\section{The Trade balance in value added}

Financial centres feature very sizeable and rising trade surpluses. In countries where financial holdings and special purpose subsidiaries are concentrated, exports and imports flows are heavily influenced by systematical misreporting of intra-firm trade transactions. Transfer pricing practices result in exports overvaluation as the value added created globally by MNEs is allocated there, promoting the build up of trade surpluses in these countries. This occurs despite financial centres differ in their production systems and each exhibits its own traits in terms of activities that MNEs subsidiaries located there specialise in.

Subsidiaries and partners of global companies may be involved in merchanting, receive royalties payments on intangibles (e.g. patents, intellectual property rights and brands); in some cases insurance and leasing subsidiaries are also located in financial centres (e.g. Cyprus and Ireland). The implicit pricing of these services show up as a difference between input purchases and ex-factory prices of the product. These activities are so pervasive that they affect aggregate headline statistics. ${ }^{1}$ Tørsløv et al. (2018) explain that transfer pricing practices in financial centres account for almost three quarters of the the discrepancy in total service balance existing within EU-trade.

Therefore, while the established literature maintain that domestic policies and monetary conditions relative to main trading partners are main determinants of external imbalances, the organisation of production networks on international and global scale is also important. In Felbermayr and Yotov (2019) words: "We do not know enough about the determinants of current account balances to set out precise numerical norms"."Policy-makers should pay more attention to establishing the conditions that make current account deficits and surpluses - and their mirror image, international capital flows - sustainable."

Resorting to a novel decomposition of trade flows by value added content, this section establishes new stylised facts on composition and patterns of trade balances in financial centres. We show that global companies contribute with their activity to determine the net trade position of financial centres in a very specific way.

\subsection{The decomposition criteria}

The goods and services we purchase and sell are composed of inputs from various countries around the world, hence the need of disentangling the different contributions to trade flows. We follow the methodology proposed by Borin and Mancini (2015) to distinguish domestic and foreign contributions and decompose gross bilateral exports into five items according to two main criteria (for further details on the underlying decomposition, see appendix A.1). ${ }^{2}$

\footnotetext{
${ }^{1}$ These operations often wash out in the current account (see Avdjiev et al., 2018) but are very relevant for trade balances as they inflate export values of financial centres, hence, giving rise to very consistent trade surpluses.

${ }^{2}$ The break down we apply to gross export flows by value added has two advantages over alternative methodologies; first, it is fully additive, hence, it does not generate biases in decomposing bilateral exports
} 
- The trade balance of each country is broken down in terms of the value added that (i) the exporting country itself and (ii) its partner economies have produced in every relevant transaction. The former component of value added is referred to as domestic value added $(D V A)$, and the latter as foreign value added $(F V A)$.

- An additional useful distinction of trade flows is in (i) transactions that involve final consumers $(D I R)$ and (ii) transactions concerning intermediate stages of global production chains and involving further re-export $(G V C)$.

This taxonomy helps understanding the mechanism generating large surpluses in euro area financial centres as well as their contribution to the creation of global value added.

In particular the external position of financial centres adds up to the total euro area surplus; differently from Germany, which is the largest contributor of all through its domestic produced value added, their surplus is entirely determined by foreign production transiting for further processing through their borders. (see chart 1).

in domestic production and other trading partners production (foreign value added). Second, it separates exports along several dimensions into 21 finely defined categories that can be easily re-grouped depending on specific focuses. In particular it distinguishes across intermediates and final goods and services and identifies when the bilateral importer directly absorb it (also after further transformations), and in which cases goods and services are further exported by the bilateral importer to other destinations. For each of them it singles out the share of domestic value added and trading partners value added. Double counted trade is separately identified (see Borin and Mancini, 2015). 
Figure 1: Net euro area trade position

as percentage of euro area GDP

-Germany - Finanical centres ॥ Other euro area countries

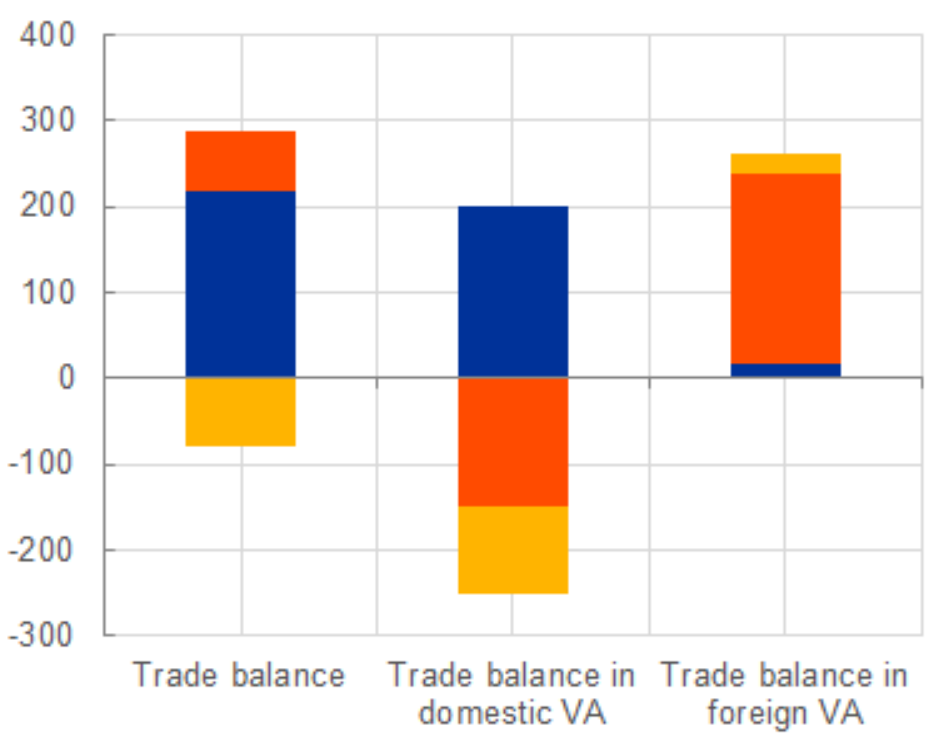

Source: Eurostat.

Notes: euro area financial centres encompasses Belgium, Cyprus, Ireland Luxembourg, Malta and the Netherlands. Last observation 2018.

\subsection{The origin of value added contained in trade balances}

Based on the break-down of trade balances just detailed, we find out that financial centres emerge from the rest of countries for some key features. Four new stylised facts are discovered about financial centres. First, the net trade balances in domestic and foreign value added regularly take on opposite sign. Since 2000 their growth has constantly outpaced that of the overall net trade position. Second, the trade surpluses in value added stemming from other countries dominate the remaining net trade components (see green bars; $F V A-D I R$ of figure 2). They are made of goods and services produced elsewhere but delivered by financial centres to final consumers.

Hence, financial centres import very little foreign value added for domestic absorption but re-export large amounts of others value added to final consumers. This is not the case in other euro area countries where trade surpluses reflect primarily domestic value added that is directly traded with the final consumers (see blue bars; $D V A-D I R$ of figure 2).

Third financial centres present large deficits in the balance of domestic value added to production that is further re-exported by the bilateral importer (see yellow bars; $D V A-$ $G V C$ of figure 2). 
Financial centres thereby tend to perform the very last stage(s) in the production chain making them located very downstream - i.e. they are closest to final consumers - than any other participant in the global production network. They receive production for further transformation but do not export their production to other countries for additional processing; hence the large deficit. ${ }^{3}$

And fourth, financial centres exhibit surpluses in domestic value added exported to directly absorbing countries twice as large as in other euro area economies (see blue bars 2 , $D V A-D I R)$.

This is all the more noteworthy as right $D V A-D I R$ makes most of the trade balance in other euro area economies. However this is also the component most likely to be contaminated with profits (value) shifting as it concerns the value that is booked in financial centres.

The four findings do not reflect a single financial centre specificity but stems from patterns common across them (see figure 3). Despite a considerable heterogeneity in the production structure, the value added composition of their trade balance is strikingly similar in this group of countries and yet very different from any other country (compare figure 3 and 4).

Figure 2: Decomposition of trade balance by value added content

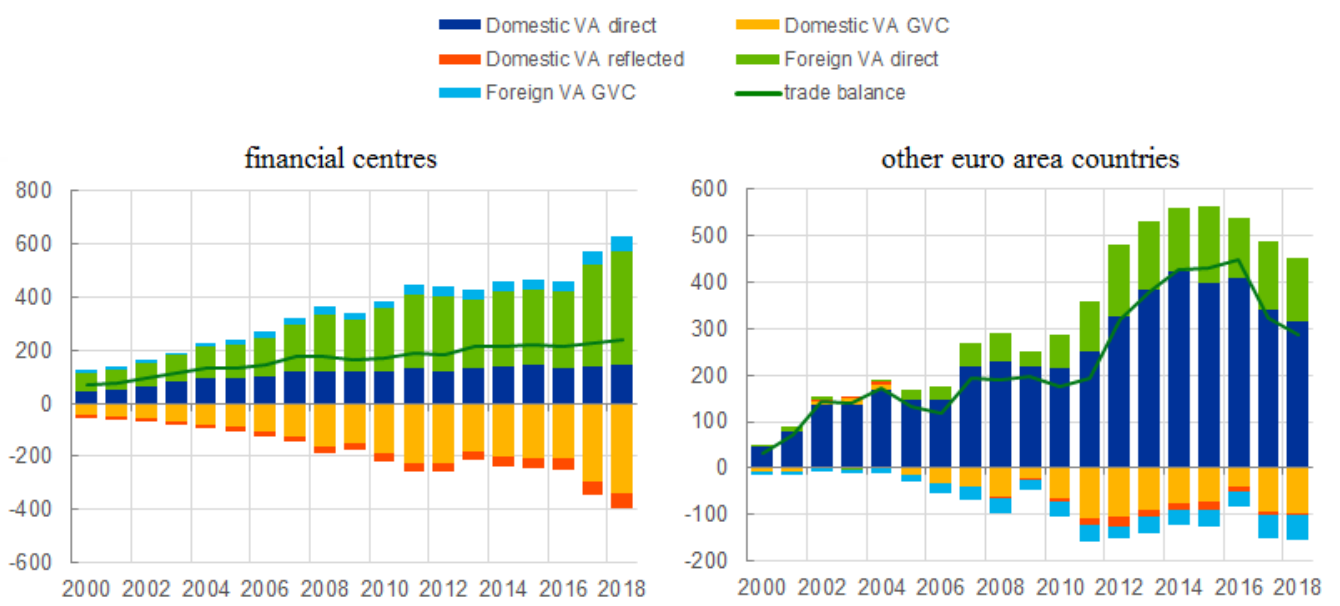

Source: authors' computations based on WIOD and ADB MRIO tables. Note: vertical axes expressed in billions USD.

\footnotetext{
${ }^{3}$ For the Netherlands some of these patterns are softened by the presence of a large, active exporting manufacturing sector.
} 
Figure 3: Trade balance in value added, financial centres
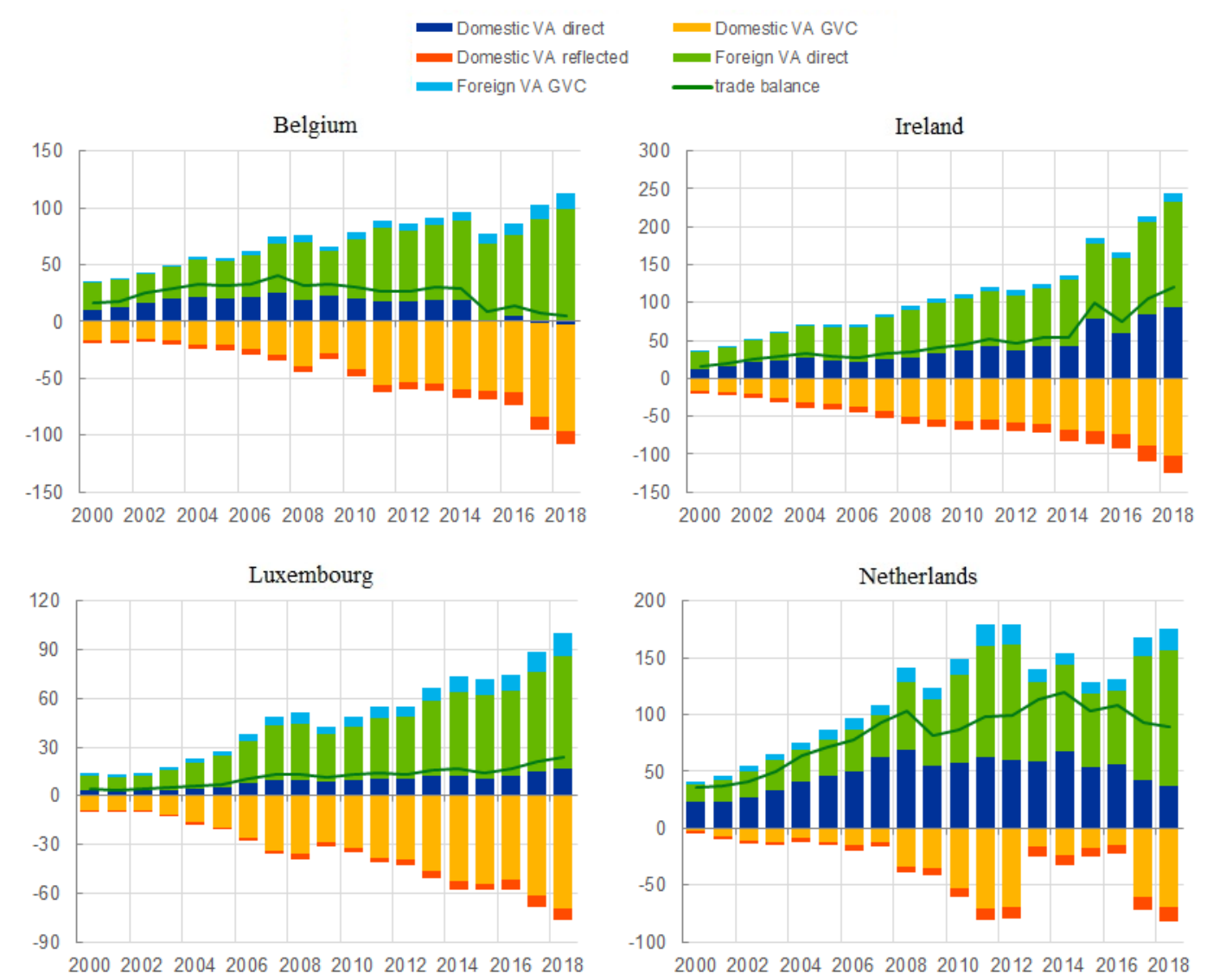

Note: vertical axes expressed in billions USD.

Source: OECD and authors' computations based on WIOD and ADB MRIO tables. 
Figure 4: The value added representation of the trade balance in global economies
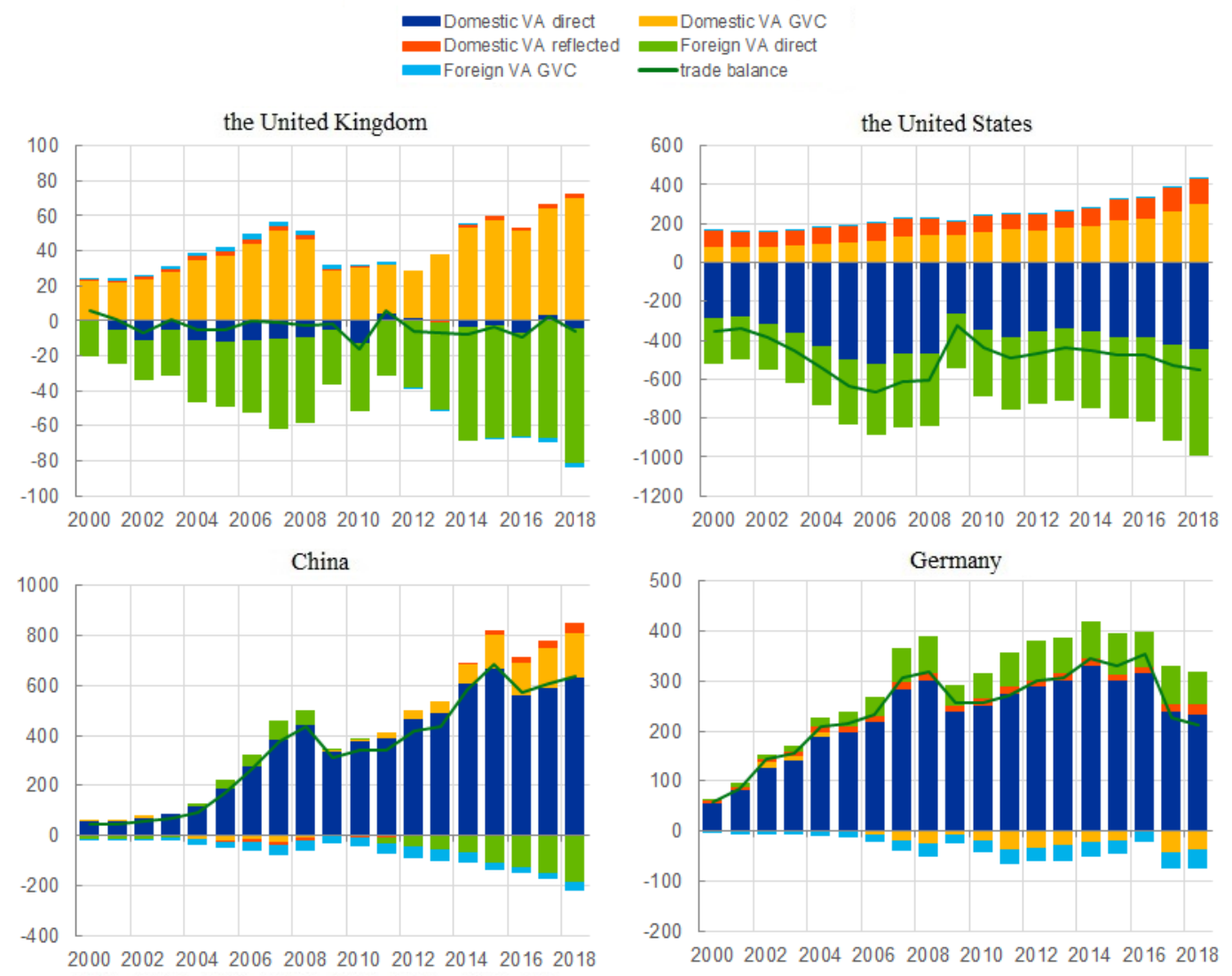

Note: vertical axes expressed in billions USD.

Source: authors' computations based on WIOD and ADB MRIO tables.

Let's repeat ourselves and recap: each main euro area financial centre (Luxembourg, Ireland, Belgium and the Netherlands) exhibit a constantly increasing trade surplus (see figure 3) mostly due to foreign value added traded directly with final consumers ( $F V A-$ $D I R)$. They all have a mirror trade deficit in domestic value added that further requires intermediate production stages $(D V A-G V C)$.

The abnormality of financial centres appears clear when compared to other countries. The trade balance components related to production chains (e.g. FVA-DIR, FVA-GVC and $D V A-G V C$ ) are inflated (both deficits and surpluses) by pervasive integration of their production system into global networks. However, GVC champions like China, Germany and the US, do not exhibit such large imbalances owing to integration in production network; most of their net positions still depend on the contribution of domestic production to foreign trade transactions (see blue bars of figure 4). Noteworthy, the US runs constant deficits in the balance of domestic value added traded with final consumers but exhibit persistent surpluses in domestic value added to intermediate stages of production chains. The euro area financial centres are US counterpart in half of these foreign trade transactions. 


\subsection{Bilateral trade balance in value added}

If goods in transit and intangibles services mask tax-avoidance strategies, then one should expect net trade positions of financial centres to primarily reflect bilateral balances with high-tax jurisdictions, thus resulting in "selective trade surpluses". In other words, transferpricing practices manipulate the allocation of values globally created by MNEs between high and low taxation countries, hence plaguing mainly the correct representation of these bilateral flows.

The bilateral trade balances of financial centres support this assumption. Financial centres indeed hold large surpluses only vis-à-vis high-taxation jurisdictions, especially euro area economies, whereas their positions with other financial centres are definitely more nuanced. When trade balances are expressed in terms of value added content, trade surpluses pertaining to exchanged $F V A-D I R$ pile up vis-à-vis main manufacturing countries; this is because imports of foreign production for direct absorption from these economies is negligible but exports is very substantial. Conversely high taxation jurisdiction exports to financial centres dominantly their domestic production of intermediates that are further processed $(D V A-G V C)$.

Also deficits with the US consist of US domestic production, which crosses the borders of financial centres but ends up elsewhere (trade balance in $D V A-G V C$ ). Financial centres are integrated in value chains in a special way: they are two way transit for regional partners and one way linked to the US - they transform and re-export to the rest of the world; as a result they exhibit deficits vis-a-vis the US, that is in deficits almost vis-à-vis any other country (see figure 5, A.4.2 and A.4.3).

Differently, net trade positions vis-à-vis other low corporate-tax jurisdictions are volatile with frequent changes from surpluses into deficits.

Finally the dynamics of the bilateral trade balance between two financial centres mirror, in some occasions, developments in net trade observed between financial centres and other euro area economies. Precisely this is the case for Luxembourg where the sudden reversal from surplus to deficit in 2013 vis-à-vis Germany and France is counterbalanced by a large trade surplus emerged over the same period vis-à-vis Ireland (see figure 5). 
Figure 5: The value added representation of the bilateral trade balance for Luxembourg
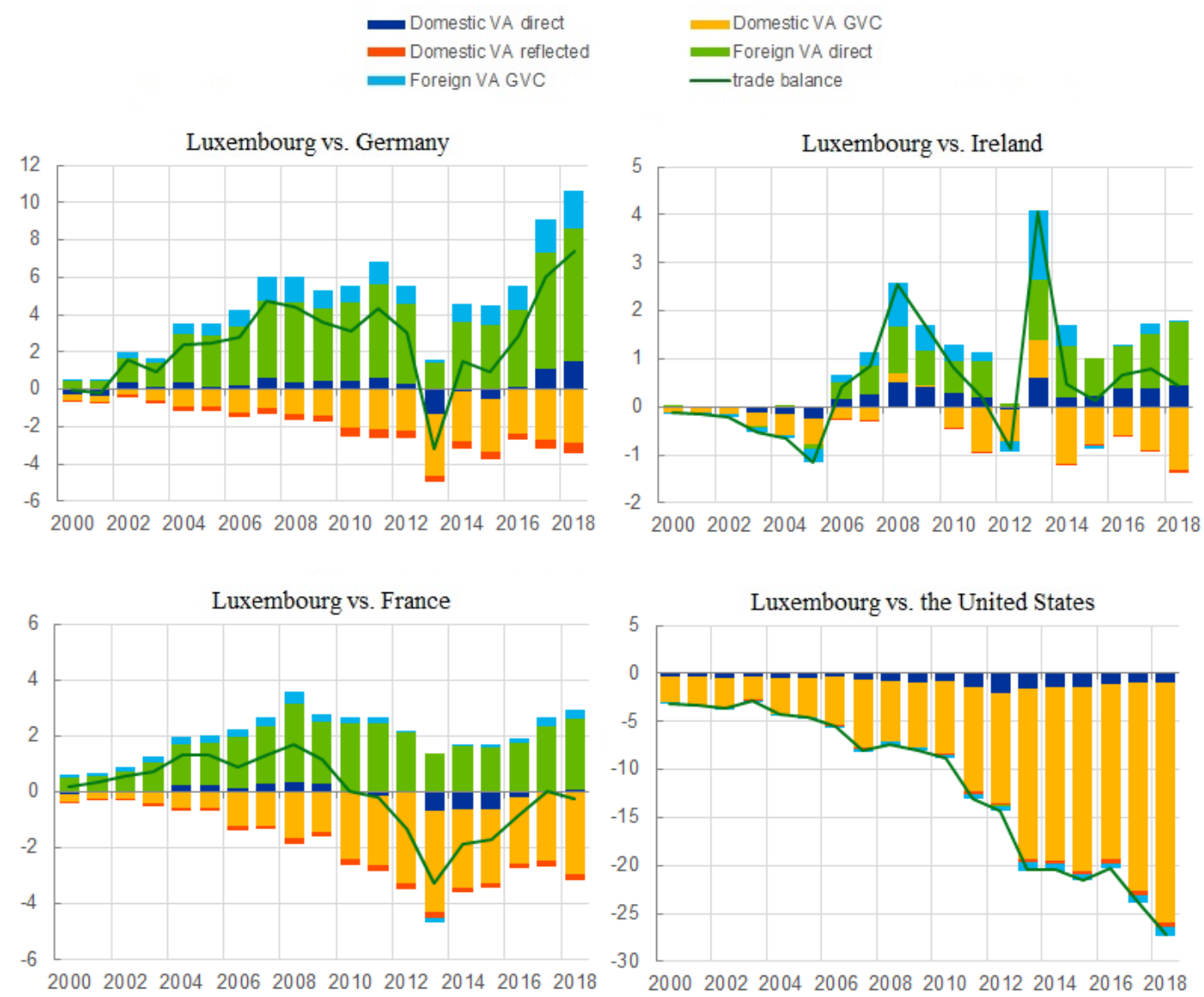

Note: vertical axes expressed in billions USD.

Source: authors' computations based on WIOD and ADB MRIO tables.

What may be occurring with the trade balance of financial centres is better understood through an example. Imagine that MNEs operate a strategic allocation of value created globally in order to optimise their fiscal burden. MNEs can export to a subsidiary operating in financial centres intermediate production for low price, hence, compressing profits earned in the exporting high tax jurisdictions. At the same time the subsidiary, located in the low-tax jurisdictions, adds complementary services (merchanting, royalties from brand and patents) and then re-export $(F V A-D I R)$ the same goods. This time the value of complementary services is included, hence, the goods are re-exported at higher prices.

To book profits in financial centres, the complementary services are allocated large fraction of the globally created value. Intuitively the convenience of transfer pricing strategies is maximised when the economy with favourable taxation regime receives the products just ahead of final sales and supply directly final consumers abroad.

This is the price gap between production and consumer price that Timmer, Dietzenbacher, Los, Stehrer and De Vries (2015) refers to and it can explain the large surplus 
identified in foreign production traded through financial centres directly with final consumers $(F V A-D I R)$.

We draw two conclusions from this exercise. First, the dissection of the trade balance in value added shows that financial centres are conduits also for real transactions. A tiny fraction of their total trade is for their own domestic consumption while a significant share of their trade instead responds to different objectives, including that of escaping profit taxation. Second the reliability of official trade balance statistics in presence of integration in production network is questionable and their determinants may not be macroeconomic imbalances but global companies strategies which fall outside the room for manoeuvre of governments.

As a result of tax-optimisation strategies pursued by global firms, the measurement of financial centres participation and location in GVC is heavily biased and fictitious macro imbalances emerge which are not real.

\section{Measures of GVC integration of financial centres}

Standard measures of GVC participation and positioning rank financial centres as the most downstream located countries in supply networks. Such a feature remained unnoticed in previous works for a twofold reason: first, most papers focused on the fragmentation of, strictly speaking, manufacturing processes across several borders and not on the contribution of complementary services to the process. Furthermore, even when the importance of complementary services, in terms of value added to the chain, was correctly identified, financial centres did not enter the picture. We draw a parallel between this feature and the role of financial centres as transit of real transactions toward other economies.

Figure 6 plots on the horizontal axis the share of domestic value added which is only indirectly exported (e.g. the part of gross exports made of domestic production which reaches final consumers after crossing at least other two borders; $D V A-G V C$ ). This is commonly referred to as forward GVC participation. On the vertical axis are the figures reporting backward GVC participation. This is given by the share of foreign production contained in gross export of each country and is the sum of foreign production that transit through a country's border to reach directly the final consumer $(F V A-D I R)$ and foreign production that crosses at least two more borders $(F V A-G V C)$. Each point on the plot identifies a pair of forward and backward links by origin-destination pair of countries.

Origins are divided into two groups: the first contains the main euro area manufacturers (Big 4) and the second contains the four main euro area financial centres plus Malta and Hungary. ${ }^{4}$ These are colour coded as blue and orange, respectively. Moreover, we single out pairs of bilateral relations between financial centres by yellow dots and in a similar manner

\footnotetext{
${ }^{4}$ Hungary is not a tax-havens but has put in place tax policies favouring MNEs relocation there (see Blanchard, Acalin et al., 2016).
} 
pairs of bilateral relations between main EU countries (Big 4) and financial centres are in a lighter shade of blue. We find out that:

1. financial centres features the largest backward GVC participation of all;

2. the degree of backward participation of financial centres falls sensibly to more normal levels vis-à-vis other financial centres (e.g. less integrated with other financial centres, see yellow dots).

3. The four largest euro area economies maintain the strongest forward GVC participation with financial centres (see light blue dots).

Figure 6: The participation and positioning of financial centres in GVCs

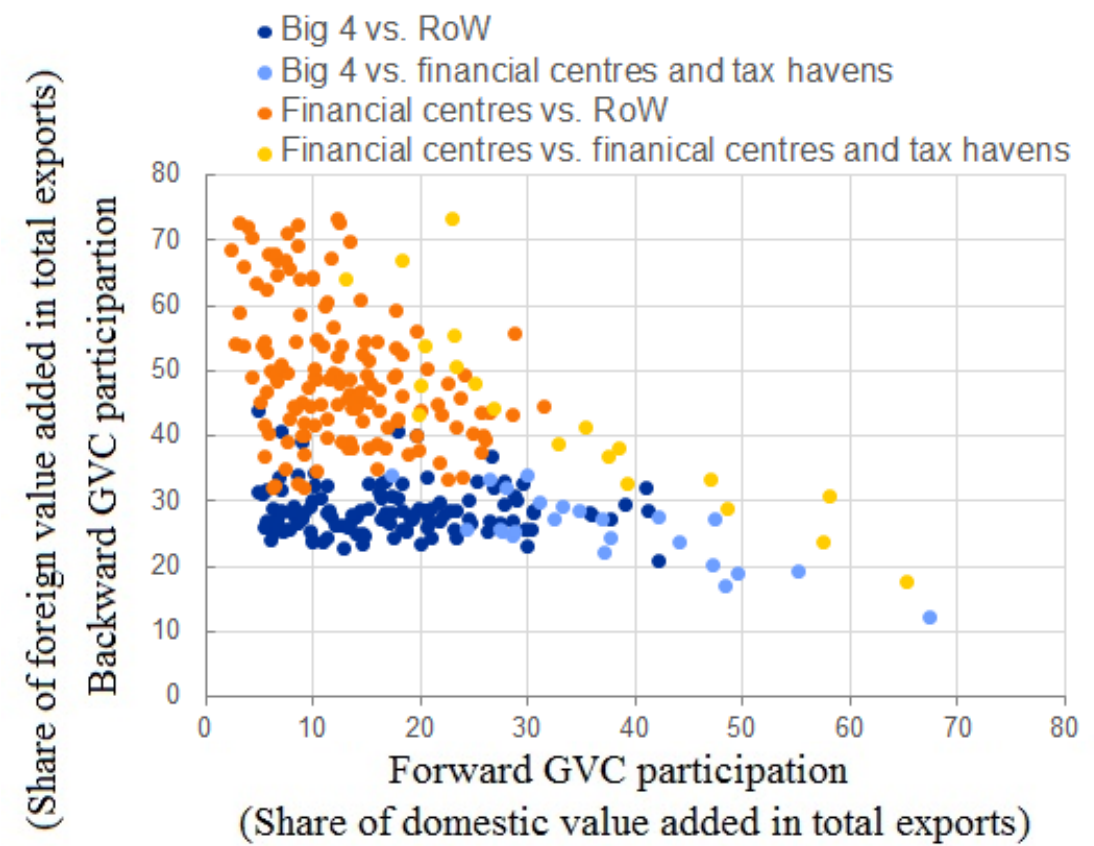

Note: Big 4 consists of Germany, Italy, France and Spain. Financial centres are Belgium, Ireland, Luxembourg and the Netherlands. Tax havens are referring to Hungary, and Malta. Total exports have been netted out of double counting. Sources: WIOD, authors' calculations

However this divide between financial centres and other countries in terms of GVC participation can be entirely traced back to finished goods produced in supply network. The GVC indices of participation and positioning converge when computed limitedly to intermediate stages of production (see figure 7). In this case, high taxation economies gain in terms of backward GVC participation and financial centres in terms of forward integration (see right hand side panel of figure 7). The positioning of financial centres in GVCs remain atypically downstream in final goods and reflects their specialisation in services which enter the chain at the end. 
Figure 7: The participation and positioning in GVCs by product

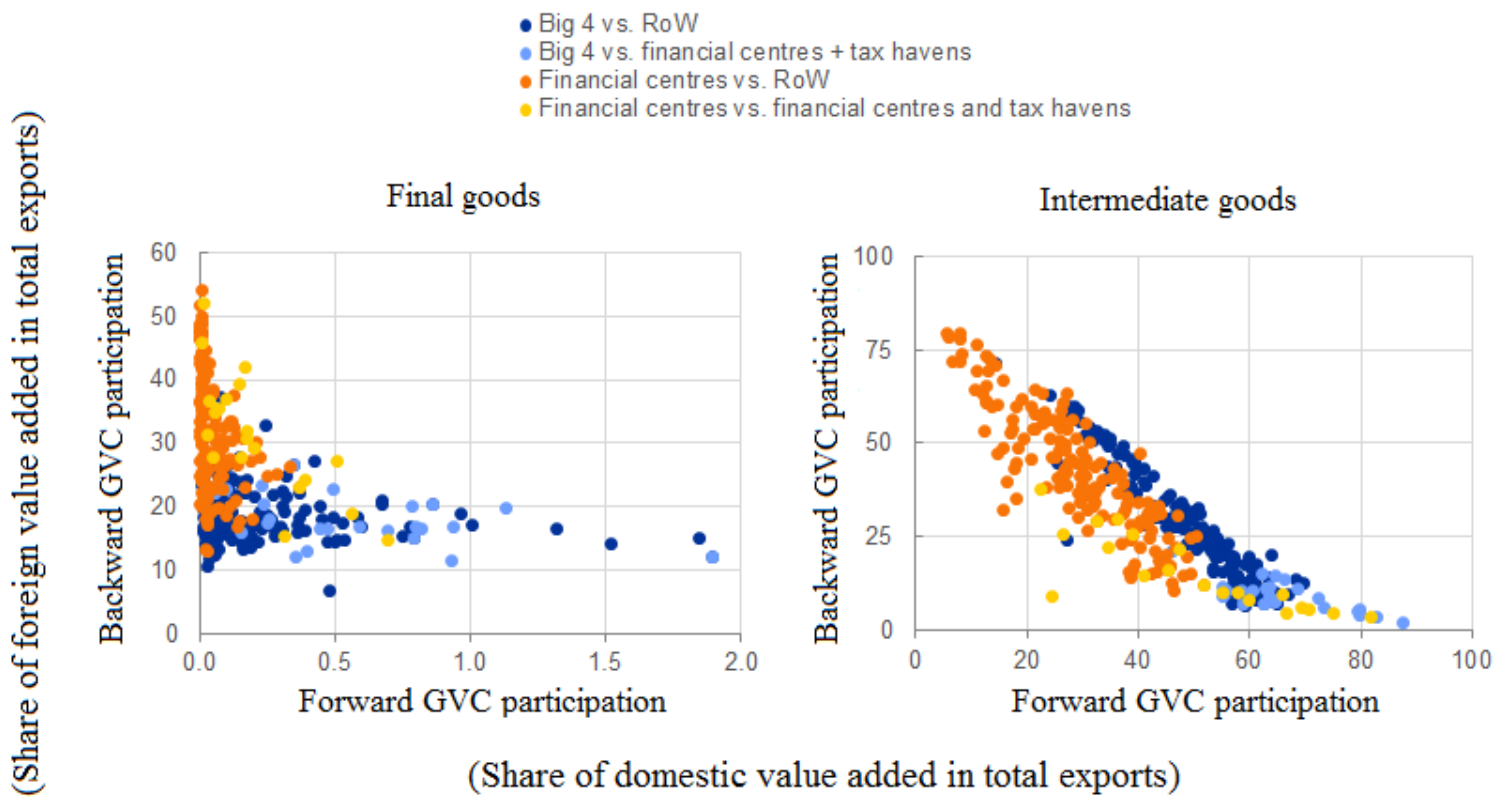

Note: Big 4 consists of Germany, Italy, France and Spain. Financial centres are Belgium, Ireland, Luxembourg and the Netherlands. Tax havens are referring to Hungary, and Malta. Total exports have been netted out of double counting. Sources: WIOD, authors' calculations

These stylised facts raise more questions than they answer. Why should financial centres be less integrated with other similar economies (other financial centres)? Why do main manufacturers appear forward integrated especially with financial centres rather than with other manufacturing economies? A potential explanation is that companies aiming at minimising tax burden from a global perspective will operate strategic allocation of profits by rising the value of services supplied by financial centres at the very end of the chain. Thereby, a side effect of profit shifting is that countries, not expected to interact intensively according to the universal law governing foreign trade, appear instead fictitiously integrated. On these grounds, in order to correct BEPS distortions in GVC measures we resort to the predictive power of the gravity law.

\section{Trade surpluses in financial centres according to gravity law}

The gravity equation has since its introduction in 1964 (see Tinbergen 1964) been widely used to analyse determinants of bilateral trade flows, and its theoretical foundation has been further developed and justified by Anderson (1979), Bergstrand (1985; 1989) and Anderson and van Winccop (2003) amongst others.

Despite its past proven stability and explanatory power, recent work has shown that the model cannot provide a correct assessment of the determinants of bilateral trade balances 
in the light of cross-border production fragmentation within GVCs (Noguera, 2012). In a closely related paper Cuñat and Zymek (2019) apply a gravity framework to study bilateral trade imbalances with a specific focus on the United States and conclude that factors determining heterogeneity of bilateral trade balances are not yet fully understood. In this paper we show that part of this heterogeneity can be accounted by transfer practices and correct for them.

The gravity specification builds on the seminal contribution in Anderson and van Winccop (2003) and includes inward and outward multilateral trade resistance terms among regressors. We control for the fact that bilateral exports from country $i$ to country $j$ depends, beside bilateral trade barriers, also on $i$ 's global remoteness that affects its possibility to supply other destinations (outward resistance) as well as $j^{\prime} s$ possibility to import from alternative sources (inward resistance). However, we deviate from the common approach of employing exporter and importer or exporter-time and importer-time fixed effects to control for resistances (see for instance Redding and Venables, 2004 and Feenstra, 2015). Instead, proxies for remoteness are constructed following a two-step procedure proposed by Baldwin, Taglioni et al. (2011), which in contrast to fixed effects does not absorb all timevarying country specific characteristics that are key to the why some countries function as financial centres. ${ }^{5}$

While applying gravity to gross exports is an established exercise in the literature, the application to value added trade is far less explored. We employ an augmented gravity equation to predict exports and imports of exported domestic production that enters global value chains (e.g. exports which is further processed by the importer and then re-exported $(E X P-D V A-G V C)$.

Our approach builds on earlier related works (Noguera, 2012; Baldwin et al., 2011) and more recent analyses (Jang and Song, 2017; Lankhuizen and Thissen, 2019). In particular, as the primary goal of the paper is to provide a tool measuring to what extent reported international trade figures are contaminated by MNEs strategies, we control for global production network including a series of extra trade terms that describe the structure of the bilateral importer's trade with the rest of the world.

In particular, Baldwin et al. (2011) points that the estimated coefficient on the GDPs should be lower for nations where trade in parts and components (a very rough measure for GVCs trade) is important and suggests to include, among determinants of a country's imports, either its exports or alternatively the trading partner demand shifters. Noguera (2012) shows that countries' bilateral exports also depend on the bilateral importer aggregate imports $(I M P-D V A-D I R$ and $I M P-D V A-G V C)$ netted of the imports from the country under consideration.

We follow a similar reasoning and include, among determinants of country $i$ 's $E X P$ -

\footnotetext{
${ }^{5}$ For details of the two-step procedure of constructing the multilateral resistance term, see chapter 3 of International Monetary Fund, 2019).
} 
$D V A-G V C$, the exports and the imports of the bilateral importer $j$ from the rest of the world. Precisely, the equation for bilateral exports of country $i$ to $j$ is augmented for the bilateral importer's exports and imports in terms of production content,excluding exports to the country under consideration $(i){ }^{6}$

This strategy is also corroborated by the recent work on the effect of re-exports in gravity estimations, Lankhuizen and Thissen (2019) nets exports of the re-exported quota; in this work we follow the value added along the chain by including re-exports to the rest of the world through $j$ as additional controls $(E X P-F V A-G V C$ and $E X P-F V A-D I R){ }^{7}$

The gravity equation takes on two specifications; a first one is applied to estimation of gross exports and export of domestic production directly to final consumers, and a second one that includes eight additional terms, representing exports and imports of the bilateral importer of domestic and foreign production. Moreover multilateral trade resistances $(M R T)$ replace the standard use of country dummies to control for origin and destination unobservable factors (see equation 1).

$$
\begin{aligned}
X_{i j t}= & \exp \left[\alpha+\sum_{t r=1}^{8} \beta_{t r} \ln \left(\gamma_{j t}^{t r}\right)+\beta_{9} \ln \left(Y_{i t}\right)+\beta_{10} \ln \left(Y_{j t}\right)+\beta_{11} \ln \left(Y_{w t}\right)+\right. \\
& +\beta_{12} \ln \left(\text { Distance }_{i j}\right)+\beta_{13} \text { Language }_{i j}+\beta_{14} \text { Border }_{i j}+\sum_{T A=15}^{18} \beta_{r} I_{i j t}+ \\
& \left.+\beta_{19} \ln M R T_{i t}^{\text {out }}+\beta_{20} \ln M R T_{j t}^{\text {in }}\right] \eta_{i j t}
\end{aligned}
$$

where the dependent variable denotes, in turn, flows of gross exports from country $i$ to country $j$ at time $t$, flows of domestic produced exports from $i$ to final importer country $j(E X P-D V A-D I R)$, flows of domestic produced exports from $i$ to country $j$ that re-export them $(E X P-D V A-G V C)$.

The first eight ( $\gamma$ 's) terms are the bilateral importer's exports and imports in domestic and foreign value added, shipped directly to final consumer country or to other intermediary countries; they are included only in the regression of $E X P-D V A-G V C .^{8}$

We maintain no a-priori on sign and magnitude of the elasticity of these eight terms. Exports of country $j$ (the bilateral importer) enter its gross output and recent works showed it to be a better measure of aggregate demand in the presence of intermediates. The

\footnotetext{
${ }^{6}$ These consists of eight terms: $E X P-D V A-D I R, E X P-D V A-G V C, E X P-F V A-D I R$ and $E X P-F V A-G V C, I M P-D V A-D I R, I M P-D V A-G V C, I M P-F V A-D I R$ and $I M P-F V A-G V C$; for details about definitions of each component see appendix A.1).

${ }^{7}$ Another recent contribution by Jang and Song (2017) works out theoretical foundations of the gravity equation in the presence of trade in intermediates. It concludes that gravity remains a valid workhorse, provided gross output replaces gross value added as a proxy for aggregate demand.

${ }^{8}$ See the exact composition of $E X P-D V A-D I R, E X P-D V A-G V C, E X P-F V A-D I R$, $E X P-F V A-G V C, I M P-D V A-D I R, I M P-D V A-G V C, I M P-F V A-D I R, I M P-F V A-G V C$ in the appendix
} 
elasticity aggregate exports of country $j$ may hence be expected to be positive. Aggregate imports of country $j$ represent a substitute to $i$ 's exports to $j$ therefore the elasticity may be negative in this case.

$Y_{i t}, Y_{j t}, Y_{w t}$ are standard gravity terms, respectively nominal GDP of the exporting, importing country and world GDP. The first two terms capture the economic mass of the two countries which determine their trade volumes; both are expected to have positive elasticity (unitary elasticity according to gravity). World GDP is expected to have negative elasticity; intuitively bilateral trade between country $i$ and country $j$ decreases relative to trade with the rest of the world as the economic size of the other countries' grows.

Distance and border capture unobservable trade barriers and common language is expected to promote bilateral trade. As for the observable factors $(I)$ we single out the trade enhancing effects of deeper economic integration by including a set of dummies which takes the value of one if the pair exporter-importer signed a free trade agreement $(F T A)$ are members of a customs union $(C U)$, common market $(C M)$ and/or economic union $(E U)$.

The final $M R T$ variables are the inverse of outward and inward multilateral resistance terms. $M R T_{\text {out }}$ increases when the weighted average of trade barriers faced by country $i$ in the global market lessens. $M R T_{\text {in }}$ captures the inverse of weighted-average trade barriers faced by rest of the world when exporting to $j$.

\section{Methodology}

The process of adjustment of trade balances for the bias related to operations by MNEs in financial centres, consists of three steps.

First we estimate via Pseudo Poisson Maximum Likelihood, a gravity equation of bilateral gross exports to obtain consistent, unbiased estimates even in presence of heteroscedasticity (see Silva and Tenreyro, 2006).

Second, we draw on the estimates of gross exports and re-scale accordingly the DVA and FVA content of reported gross exports. In particular, as shown in equation 2, re-scaled $E X P-\widehat{D V A}-D I R, E X P-\widehat{D V A}-G V C$ and $E X P-\widehat{D V A}-R E F$ are constructed by multiplying reported $E X P-D V A-D I R, E X P-D V A-G V C$ and $E X P-D V A-R E F$ for the share of predicted over actual gross exports.

$$
\widehat{V A_{i j t}}=V A_{i j t} *\left(\frac{\widehat{E X P_{i j t}}}{E X P_{i j t}}\right)
$$

The exports in value added, opportunely re-scaled to be consistent with first stage $\widehat{E X P}$, are then regressed on the same set of determinants as in equation (2). EX $\widehat{P-F} V A$ is obtained as difference between $\widehat{E X P}, E X P-\widehat{D V A}-D I R$ and $E X P-\widehat{D V A}-G V C)$.

Third, we replace reported with estimated export values when either the exporter or the importer country is one of the six euro area financial centres. 
We obtain imports as mirror statistics and compute accordingly the adjusted trade balance $(\widehat{T B}, T B-\widehat{D V A}-D I R, T B-\widehat{D V A}-G V C$ and $T B-\widehat{F V A}-G V C)$.

Section 5 discusses main findings of gravity estimations and 6 comments over a series of robustness checks we performed on the validity of our methodology and stability of our estimates. Linear projections of official trade balances on estimated trade balances are reported in the appendix A.

\section{$5 \quad$ Empirical Results}

The predicted elasticities of bilateral export flows to standard determinants are all well behaved; the augmented gravity regressions return highly significant coefficients of the expected magnitude and sign, in line with the wide literature on gravity trade. This hold equally true for regressions of bilateral gross exports, bilateral exports of domestic value added to final bilateral importer $(E X P-D V A-D I R)$ and bilateral exports of domestic value added further re-exported by the bilateral importer $(E X P-D V A-G V C)$.

$E X P-D V A-D I R$ turns out more sensitive to the size of the origin and the destination country, e.g. to the bilateral economic mass $\left(Y_{i t}, Y_{j t}\right)$ than $E X P-D V A-G V C$, (estimated coefficients are $0.84,0.89,0.77$ and 0.86 respectively, see Table 1$)$ since the latter depends also on the macroeconomic conditions of destinations indirectly reached via intermediate importers.

Free trade agreements raise bilateral exports by 22-26\%; EXP-DVA-GVC are less responsive to bilateral liberalisations because trading conditions prevailing between the bilateral importer and other destinations are relevant too. Custom unions promote direct exports to final consumers but it does not significantly improves exports in chain. Conversely setting up a common market produces beneficial effects for the domestic production exported in regional value chains $(E X P-D V A-G V C)$ by about 15 and specifically joining the European Union grants an additional $8 \%$ of exports to EU members.

Bilateral distance reduces exports very substantially and almost equally across content types; exports between trading partners that are $10 \%$ farer apart than the average is $6 \%$ below the average export value. Sharing the same language is confirmed an important promoting factor of bilateral exports, especially relevant for domestic production entering supply chains for further re-export (EXP-DVA-GVC) that is raised one third above the average by the common idiom. Sharing a common border instead boosts by about $50 \%$ exports to direct consumer but matters definitely less for exports entering production network (see Table 2).

The multilateral trade resistance terms are both well behaved; trade barriers faced by country $i$ when reaching out the global market depresses more exports of domestic production to direct final consumers whereas reducing barriers that every country face in 
Table 1: Standard determinants of bilateral exports

\begin{tabular}{lccc}
\hline \hline & $(1)$ & $(2)$ & $(3)$ \\
VARIABLES & EXP & EXP DVA DIR & EXP DVA GVC \\
\hline & & & \\
& & & \\
$\ln \left(Y_{i t}\right)$ & $0.772^{* * *}$ & $0.838^{* * *}$ & $0.767^{* * *}$ \\
& $(0.00670)$ & $(0.00691)$ & $(0.00725)$ \\
$\ln \left(Y_{j t}\right)$ & $0.811^{* * *}$ & $0.892^{* * *}$ & $0.856^{* * *}$ \\
& $(0.00932)$ & $(0.0103)$ & $(0.0463)$ \\
$\ln \left(Y_{w t}\right)$ & $-0.352^{* * *}$ & $-0.649^{* * *}$ & $-0.828^{* * *}$ \\
& $(0.0336)$ & $(0.0345)$ & $(0.0458)$ \\
$F T A_{i j t}$ & $0.220^{* * *}$ & $0.260^{* * *}$ & $0.0892^{* *}$ \\
& $(0.0559)$ & $(0.0471)$ & $(0.0447)$ \\
$C U_{i j t}$ & 0.0480 & $0.155^{* *}$ & -0.105 \\
& $(0.0721)$ & $(0.0738)$ & $(0.0728)$ \\
$C M_{i j t}$ & 0.0535 & $0.138^{* * *}$ & $0.156^{* * *}$ \\
& $(0.0421)$ & $(0.0417)$ & $(0.0487)$ \\
$E U_{i j t}$ & 0.0624 & $0.108^{*}$ & $0.0809^{*}$ \\
& $(0.0564)$ & $(0.0625)$ & $(0.0472)$ \\
Observations & 24,600 & 24,600 & 24,600 \\
$\mathrm{R}^{2}$ & 0.791 & 0.809 & 0.739 \\
\hline
\end{tabular}

Robust standard errors in parentheses *** $\mathrm{p}<0.01,{ }^{* *} \mathrm{p}<0.05, * \mathrm{p}<0.1$

Table 2: The gravity estimations on bilateral exports, trade barriers

\begin{tabular}{|c|c|c|c|}
\hline VARIABLES & $\begin{array}{c}(1) \\
\text { EXP }\end{array}$ & $\begin{array}{c}(2) \\
\text { EXP DVA DIR }\end{array}$ & $\begin{array}{c}(3) \\
\text { EXP DVA GVC }\end{array}$ \\
\hline $\ln \left(\right.$ Distance $\left._{i j}\right)$ & $\begin{array}{c}-0.636^{* * *} \\
(0.0115)\end{array}$ & $\begin{array}{c}-0.592^{* * *} \\
(0.0106)\end{array}$ & $\begin{array}{c}-0.664^{* * * *} \\
(0.0103)\end{array}$ \\
\hline Language $_{i j}$ & $\begin{array}{c}0.175^{* * *} \\
(0.0324)\end{array}$ & $\begin{array}{l}0.204^{* * *} \\
(0.0284)\end{array}$ & $\begin{array}{l}0.356^{* * *} \\
(0.0485)\end{array}$ \\
\hline Border $_{i j}$ & $\begin{array}{l}0.544^{* * * *} \\
(0.0414)\end{array}$ & $\begin{array}{l}0.581^{* * * *} \\
(0.0392)\end{array}$ & $\begin{array}{l}0.296^{* * *} \\
(0.0351)\end{array}$ \\
\hline $\ln \left(M R T_{i t}^{o u t}\right)$ & $\begin{array}{c}0.340^{* * *} \\
(0.0369)\end{array}$ & $\begin{array}{l}0.462^{* * *} \\
(0.0374)\end{array}$ & $\begin{array}{l}0.556^{* * *} \\
(0.0384)\end{array}$ \\
\hline $\ln \left(M R T_{j t}^{i n}\right)$ & $\begin{array}{c}0.357^{* * *} \\
(0.0400)\end{array}$ & $\begin{array}{l}0.598^{* * * *} \\
(0.0420)\end{array}$ & $\begin{array}{l}0.266^{* * *} \\
(0.0535)\end{array}$ \\
\hline $\begin{array}{l}\text { Observations } \\
\mathrm{R}^{2}\end{array}$ & $\begin{array}{c}24,600 \\
0.791\end{array}$ & $\begin{array}{c}24,600 \\
0.809\end{array}$ & $\begin{array}{c}24,600 \\
0.739\end{array}$ \\
\hline
\end{tabular}

Robust standard errors in parentheses *** $\mathrm{p}<0.01,{ }^{* *} \mathrm{p}<0.05,{ }^{*} \mathrm{p}<0.1$ 
exporting to $j$ positively affects primarily exports in chain $(E X P-D V A-G V C)$ from $i$ to $j$.

Regarding the novelty of our approach, e.g. the introduction of the trade structure of the bilateral importer in the equation for $(E X P-D V A-G V C)$, we find that imports from other countries mostly tend to depress bilateral exports from $i$ to $j$ except when imports from $i$ is of production from other sources and it is for final absorption in $j(0.85$, see Table 3).Thereby other countries are to be considered alternative sources.

The four terms representing $j$ 's exports to the rest of the world are not of immediate interpretation. The more $j$ exports to other countries its own production directly for final absorption, or other' production (excluding $i$ from the set of partners) for further re-export $(E X P-D V A-D I R, E X P-F V A-G V C)$ the less it trades with $i$. However the exports of $i$ to $J$ are strengthened by the exports of the latter which is integrated in supply network. The elasticity to EXP $-D V A-G V C$ and $E X P-F V A-D I R$ are positive and highly significant. The coefficient on $E X P-F V A-D I R$ of $i$ 's $E X P-D V A-G V C$ is especially large; this can be better understood considering that in this case the domestic production of $i$ passes through $j$ for further processing but ends up lumped in the $j$ 's $E X P-F V A-D I R$, hence the strong complementarity between the two terms. ${ }^{9}$

Our analysis confirm established results of the gravity literature but also establishes some novel ones, especially on determinants of the bilateral exports of production integrated in international value chains. In particular it shows how these transactions are also shaped by the importer integration in production chains. The empirical evidence tends to support the conclusion that the integration of $j$ with the rest of the world negatively affects bilateral exports from $i$, unless they concern production of these two countries integrated in GVCs.

\subsection{The correction of bilateral trade balances of euro area financial cen- tres}

We rely on our estimates to obtain predicted values for bilateral trade relationship involving financial centres either as exporter or as importer, which replace the official statistics. Imports are obtained through mirror statistics and revised trade balance are the difference of estimated exports and imports.

In particular, once idiosyncrasies existing in trade flows of financial centres have been identified and eliminated by bringing their trade values in line with those predicted by trade gravity law, trade surpluses tend to disappear.

Figure 8 plots the revised trade balance for the four main euro area financial centres. Compared to the pre-treatment balances the Belgium's surplus in 2014 shrinks from $\$ 30$ to just $\$ 7$ billions, the correction for Ireland is even wider with a positive net position dropping

\footnotetext{
${ }^{9}$ Remember that the controls for the trade structure of the bilateral importer were constructed taking care of netting the trade flows concerning the original $i$ exporter.
} 
Table 3: Regression results of gravity estimation on exports, determinants of value added trade in GVC

\begin{tabular}{lc}
\hline \hline VARIABLES & EXP DVA GVC \\
\hline $\ln \left(\right.$ IMP-DVA-DIR $\left._{j t}\right)$ & $-1.613^{* * *}$ \\
& $(0.145)$ \\
$\ln$ IMP-DVA-GVC $\left._{j t}\right)$ & $-0.338^{* * *}$ \\
& $(0.0674)$ \\
$\ln \left(\right.$ EXP-DVA-DIR $\left._{j t}\right)$ & $-1.114^{* * *}$ \\
& $(0.156)$ \\
$\ln \left(\right.$ EXP-DVA-GVC $\left._{j t}\right)$ & $0.867^{* * *}$ \\
& $(0.127)$ \\
$\ln \left(\right.$ IMP-FVA-DIR $\left._{j t}\right)$ & $0.846^{* * *}$ \\
& $(0.137)$ \\
$\ln \left(\right.$ IMP-FVA-GVC $\left._{j t}\right)$ & $-0.570^{* * *}$ \\
& $(0.0949)$ \\
$\ln \left(\right.$ EXP-FVA-DIR $\left._{j t}\right)$ & $2.306^{* * *}$ \\
& $(0.153)$ \\
$\ln \left(\right.$ EXP-FVA-GVC $\left._{j t}\right)$ & $-0.382^{* * *}$ \\
& $(0.106)$ \\
& 24,600 \\
Observations & 0.739 \\
R-squared
\end{tabular}

Robust standard errors in parentheses *** $\mathrm{p}<0.01,{ }^{*} * \mathrm{p}<0.05,{ }^{*} \mathrm{p}<0.1$ 
from $\$ 50$ to $\$ 10$ billion, while the Netherlands undergoes the largest surplus reduction by about 100 billion (from $\$ 120$ to $\$ 20$ billion). The correction for Luxembourg is not as large and a gap between reported and estimated trade balance opens only starting around 2005, hinting to some change in their role of financial centre ahead of the great financial crisis; the surplus is however cut by a half by our correction in 2014. The revisions implemented on single components are important, they halve the partial trade balances $(F V A-D I R$ and in $D V A-G V C)$.

These corrections are reflected in the trade balance of all other countries, the most relevant are reported in the appendix A.6. As a result of our exercise the deficit of the US expands while the surplus of China shrinks substantially by almost $\$ 200$ million. The very large correction may in this case also reflect the over-invoicing of Chinese export used to bypass capital controls. Direct investments into China, which are restricted by law, are masked through international payments to Chinese companies for exports to MNEs subsidiaries located in euro area financial centres.

A downward revision relative to the official statistics is also operated on Germany net trade surplus, on France and Portugal position and to a smaller degree on Spain net position that zeroes from positive in 2014. No correction is implemented on Italy's net trade position which appear in line with what predicted by the gravity law. Overall the correction depends on how off from projected trajectories are the reported bilateral exports between financial centres and other countries.

The total correction for the four euro area financial centres sums up to about $\$ 170$ billion in 2014; such amount is comparable to the estimates on the amount of profit shifted globally obtained through different methodologies. For instance Bolwijn et al. (2018) uses FDI transactions of SPE located in financial centres and estimates pre-taxes profits to be between $\$ 330-450$ billion, of which two thirds pertaining to advanced economies and one third to emerging economies. Tørsløv et al. (2018) use differential in foreign investment yields to correct the official income balance (which turns from a positive $0.3 \%$ to a $-0.3 \%$ of euro area GDP). They also use mirror statistics to correct for under-reporting of imports from financial centres. Their revised figures for the euro area net trade surplus as a whole are not major, summing to half a percentage point of euro are GDP (from almost 5 to above 4\%, see Figure A.5.1 in the appendix). Also in their case like in our exercise, the largest correction are operated on the trade balance of the Netherlands and Ireland. 
Figure 8: Revised trade balance of the four main euro area financial centres
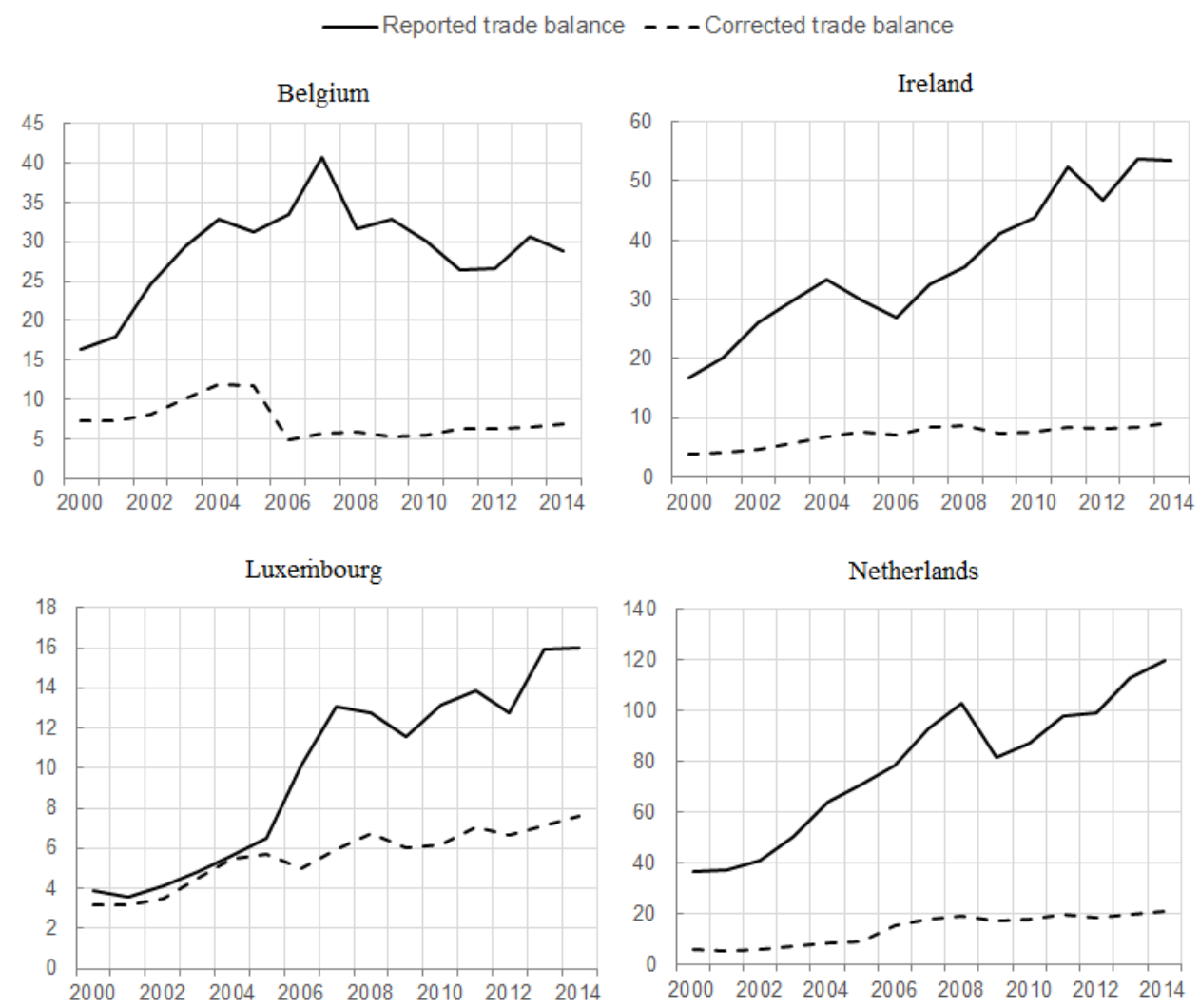

Note: vertical axes expressed in billions USD.

Source: OECD and authors' computations based on WIOD tables

At last we also recompute the correct position and location of financial centres and compare them with other main euro area economies. Their participation to GVC remain backward oriented and downstream located but definitely to a lesser extent than before our reassessment, and some heterogeneity across bilateral positions is restored (see figure 8 and 2). 
Figure 9: Corrected participation and positioning of financial centres in GVCs

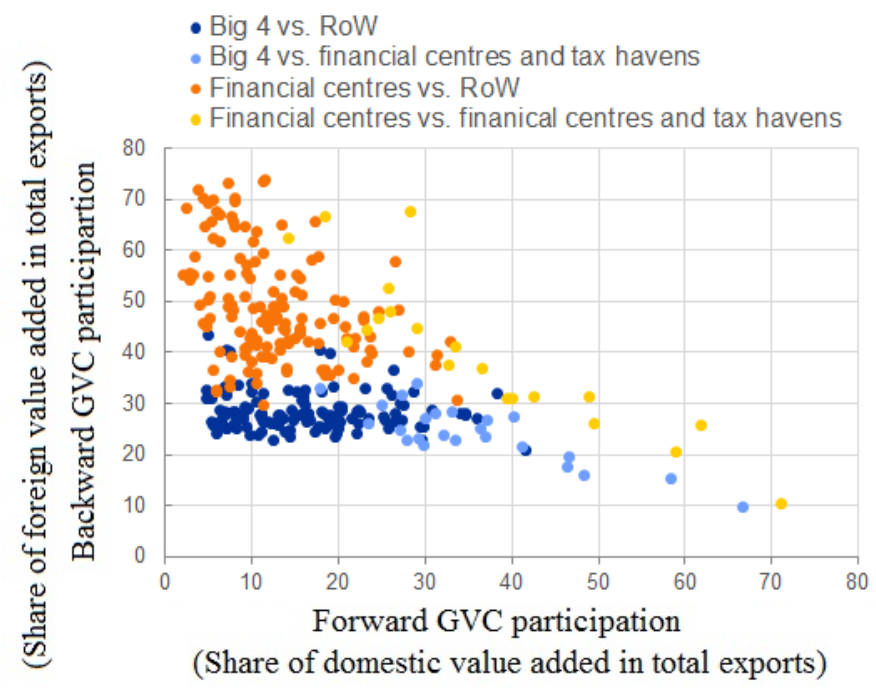

Note: Big 4 consists of Germany, Italy, France and Spain. Financial centres are Belgium, Ireland, Luxembourg and the Netherlands. Tax havens are referring to Hungary, and Malta. Total exports have been netted out of double counting. Sources: WIOD, authors' calculations

\section{Robustness}

We carry out four different robustness checks on our gravity estimations. Each validation exercise has been performed on the three components of exports flows considered in the paper.

Beside robustness validation, we have preliminarily linearly projected reported on predicted trade balances (see results in A.3) and verified that gravity predictions prove strongly correlated with official figures (coefficient about unity for $T B-D V A-D I R$ and $\widehat{T B-F V A}$; and 0.8 on $T B-D V A-G V C$ ). This is a rather good result compared to previous works that failed to explain empirically net trade external positions. Davis and Weinstein (2002) refer to the "Mystery of excess trade balances" and suggests it may arise due to highly specialised intermediates and macro policies. Felbermayr and Yotov (2019) claim to have solved the puzzle of too large trade imbalances and obtained a good fit of net trade balances by imposing in the equation specification an entire set of dummies that controls for country and country pair heterogeneity. Our results are as encouraging in this respect; we still obtain good predictions of the trade balance components and compared to theirs we do not resort to dummies for country heterogeneity which would absorb a relevant fraction of variability, preventing us from identifying the full effects of a wide range of factors on trade, including bilateral and multilateral trade resistances.

Gravity specification with origin destination fixed effects. The adjustments of 
trade statistics we seek through gravity estimations require to exclude, from the equation specification, fixed effects that normally control for unobservable heterogeneity across countries. They are generally particularly useful to capture any form of remoteness and barrier to trade. However the "financial centres effects", that we try to identify and correct, would be absorbed in the coefficient of country dummies, lumped together with several others. For this reason we have adopted Baldwin's approach by including multilateral resistance terms $(M R T)$ as additional controls in the equation. They also proxy remoteness and capture unobservable barriers. We test the robustness of our estimates to the replacement of $M R T$ with exporter and importer fixed effects. As a result, the sign and the significance of estimated elasticities are preserved; the coefficients tend to shrink in size because their interpretation is different. They are this time specifically identified based only on bilateral country-pair heterogeneity, whereas the country heterogeneity is subsumed in the fixed effect. For instance, we cannot interpret a positive elasticity on the exporter $Y_{i t}$ as evidence that richer countries trade more among themselves but as the positive effects on exports induced by an increase in the economic mass of exporter $i$ above its average value.

Gravity on predicted values of bilateral exports. As a second check we have replaced official with predicted export flows in any bilateral relationship held by financial centres with other countries and proceeded to re-estimate the gravity on the adjusted export flows. The exercise is used to verify that misreporting by financial centres do not plague the elasticities estimated via gravity. We notice three differences compared to our benchmark regression.

- The elasticity of $M R T^{i n}$ increases, implying that bilateral exports are more sensitive to changes in trade barriers faced by other countries when exporting to $j$ ( e.g. new trade barriers depress more exports of non financial centres). Intuitively the export flows of financial centres respond to somewhat different incentives from those governing trade flows elsewhere and this makes their exports resilient to common trade barriers. An alternative and consistent explanation is that financial centres specialise in digital services that face lower obstacles to travel far.

- Exports from $i$ to $j$ is less sensitive to the trade structure of $j$.

- The significance of the EU membership is restored. The elasticities of the EU dummy are positive and significant on each export component. Therefore biases in official trade statistics of financial centres lead to perceive as less positive the effects of EU integration on regional trade.

Linear gravity specification. It is widely accepted that PPML is to be preferred over linear gravity estimations of log-linearised equations because estimates are not biased by the presence of heteroscedasticity, we however verify that our results are consistent with alternative estimation methodology, e.g. linear estimation. 
PPML provides more precise and more significant estimates; in linear estimation some coefficient are oddly low $\left(Y_{j t}\right)$ and others take on the wrong sign FTA. The only improvement is recorded in the estimation of the elasticity to distance that is equal to unity, as predicted by the gravity low.

Gravity results when substitutability across varieties changes. As a fourth and last robustness check we impose alternative values of the elasticity of substitution across varieties $(\sigma)$ in the computation of the MRT terms. A value of 3 is suggested by the empirical literature that estimated this parameter; we increase and reduce substitutability across goods by raising $\sigma$ to 4 and then lowering it to 2. Such changes produce the expected results: as heterogeneity across varieties falls (substitutability rises to 4), the elasticity to both $M R T_{\text {in }}$ and $M R T_{\text {out }}$ rises. The opposite is true when $\sigma$ takes on the value of 2 ; lower substitutability across varieties leads to trade flows reacting less to changes in trade barriers. However the other elasticities are overall not significantly influenced, not even those on distance, confirming robustness of our estimates to the specification of technical parameters.

Overall we conclude that our estimates are not driven by preferences for one methodology over the others.

\section{Concluding Remarks}

This paper contributes to the literature on global imbalances and profit shifting along two dimensions.

First it identifies unique features of trade balance common across financial centres through a novel decomposition of the value content of trade balances that opportunely distinguishes domestic production from trading partners' production; exports absorbed by the bilateral importer and export further re-exported. The decomposition highlights, for the first time the pervasiveness in the external statistics of financial centres of items transiting there but consumed elsewhere and create a parallel between their role of conduit of capitals and conduit of real products. We also make an attempt to connect regularities showing up in headline external statistics to the MNEs tax-optimisation strategies. As the business size of these companies is often bigger than the hosting economy, they shape macro statistics returning a falsified picture of these countries macro conditions and imbalances. Therefore the external position from official statistics of financial centres are to be taken with a grain of salt as well as their GVC positioning and participation computed from the inter countries input output tables.

The paper works through gravity estimations to clean reported figures for the effect of MNEs. The gravity equation is expanded to control for the effect on bilateral trade of production chains encompassing several countries. We find broad evidence that trade with other countries act as substitute of bilateral exports from $i$ to $j$ unless the trade flows 
concern transactions of production integrated in the same value chains. In this case exports and imports of the direct importer $(j)$ turn out complements of $i$ 's bilateral exports.

The revised trade balances suggest that profit shifting, involving main euro area financial centres exhibit a positive trend and may amount to around $\$ 170$ billion in 2014 . Their large surpluses disappear into more balanced position. The corrections reflect mostly important reductions in exports of their domestic production that is directly absorbed by the bilateral importer $(E X P-D V A-D I R)$; this is noticeably the value booked in financial centres. Their participation in GVC is reduced but their positioning remain downstream, owing to the specialisation of these countries in end of the chain intangible services.

Our approach is an alternative, not very different in nature, to those analyses that rely on investment yield differentials across countries, or on FDI of foreign owned companies to gauge a measure of profit shifting. While our correction does not pretend to be exhaustive nor to nail down the exact amount of tax avoidance, it has the merit to look at misreporting of official statistics in financial centres from an alternative perspective and show a new direction that can be pursued in other studies.

A way forward for researchers when assessing the global magnitude of profit shifting is to rely on multiple measurement instruments and source of information, including micro data sourced directly from global MNEs balance-sheets. 


\section{References}

Alvaredo, F., Chancel, L., Piketty, T., Saez, E., Zucman, G., 2018. World inequality report 2018. Belknap Press.

Anderson, J., 1979. A theoretical foundation for the gravity equation. The American Economic Review 69.

Anderson, J., van Winccop, E., 2003. Gravity with gravitas: a solution to the border puzzle. American Economic Review 93, 170-192.

Avdjiev, S., et al., 2018. Tracking the international footprints of global firms. BIS Quarterly Review, March .

Baldwin, R., Taglioni, D., et al., 2011. Gravity chains: Estimating bilateral trade flows when parts and components trade is important. w16672, National Bureau of Economic Research.

Bergstrand, J., 1985. The gravity equation in international trade: some microeconomic foundations and empirical evidenc. The Review of Economics and Statistics 67, 474-481.

Bergstrand, J., 1989. The generalized gravity equation, monopolistic competition and the factor-proportions theory in international trade. The Review of Economics and Statistics $71,143-153$.

Blanchard, O., Acalin, J., et al., 2016. What does measured FDI actually measure? Technical Report.

Bolwijn, R., Casella, B., Rigo, D., 2018. An fdi-driven approach to measuring the scale and economic impact of beps. Bolwijn, R., Casella, B., and Rigo, D.(2018). An FDIdriven approach to measuring the scale and economic impact of BEPS. Transnational Corporations 25, 107-143.

Borin, A., Mancini, M., 2015. Follow the value added: bilateral gross export accounting. Bank of Italy Temi di Discussione (Working Paper) No 1026.

Cuñat, A., Zymek, R., 2019. Bilateral trade imbalances .

Davis, D.R., Weinstein, D.E., 2002. The mystery of the excess trade (balances). American Economic Review 92, 170-174.

Dharmapala, D., 2019. Profit shifting in a globalized world, in: AEA Papers and Proceedings, pp. 488-92.

Dowd, T., Landefeld, P., Moore, A., 2017. Profit shifting of us multinationals. Journal of Public Economics 148, 1-13. 
Feenstra, R.C., 2015. Advanced international trade: theory and evidence. Princeton university press.

Felbermayr, G.J., Yotov, Y., 2019. From theory to policy with gravitas: A solution to the mystery of the excess trade balances .

Flaaen, A., et al., 2017. The role of transfer prices in profit-shifting by us multinational firms: Evidence from the 2004 homeland investment act. Finance and Economics Discussion Series 55.

Guvenen, F., Mataloni Jr, R.J., Rassier, D.G., Ruhl, K.J., 2017. Offshore profit shifting and domestic productivity measurement. Technical Report. National Bureau of Economic Research.

International Monetary Fund, 2019. The Determinants of bilateral trade and spillovers from tariffs. Technical Report. International Monetary Fund.

Jang, S., Song, E.Y., 2017. Gravity with intermediate goods trade. East Asian Economic Review 21, 295-315.

Lankhuizen, M., Thissen, M., 2019. The implications of re-exports for gravity equation estimation, nafta and brexit. Spatial Economic Analysis 14, 384-403.

Noguera, G., 2012. World economic outlook, april 2019 : Growth slowdown, precarious recovery. Job Market Paper, Columbia University .

Overesch, M., 2009. The effects of multinationals' profit shifting activities on real investments. National Tax Journal , 5-23.

Redding, S., Venables, A.J., 2004. Economic geography and international inequality. Journal of international Economics 62, 53-82.

Silva, J.S., Tenreyro, S., 2006. The log of gravity. The Review of Economics and statistics 88, 641-658.

Timmer, M.P., Dietzenbacher, E., Los, B., Stehrer, R., De Vries, G.J., 2015. An illustrated user guide to the world input-output database: the case of global automotive production. Review of International Economics 23, 575-605.

Tinbergen, J., 1964. Shaping the world economy: Suggestions for an international economic policy. American Journal of Agricultural Economics 46, 271.

Tørsløv, T.R., Wier, L.S., Zucman, G., 2018. The missing profits of nations. Technical Report. National Bureau of Economic Research. 


\section{A Appendix}

\section{A.1 The decomposition of gross exports in domestic and foreign value added}

In this paper we follow the decomposition proposed by Borin and Mancini (see Borin and Mancini, 2015) as it holds two advantages on others. First it does not generate downward biases of the foreign value added in export flows nor overestimate the domestic value added in gross exports. Second it is fully additive, hence allows grouping countries at a later stage.

The 21 items were then bundled in 5 broader categories according to two broad criteria. First dividing domestic from foreign value added in exports ( $D V A$ versus $F V A$ ) and second breaking down what part of domestic and foreign is a final sale to the bilateral importer (direct trade) and what is further re-exported by the bilateral importer (GVC). As mentioned in the main text the underlying main trade balance components.

DVA-DIR Domestic value added in bilateral exports absorbed by bilateral importer.

- 1a "domestic value added (VA) in final good to the final bilateral importers"

- 1b "domestic VA in intermediate exports absorbed by bilateral importers as domestic final goods after additional processing stages"

- 2a "domestic VA in intermediate exports absorbed by direct importers as local final goods"

- $2 \mathrm{~b}$ "domestic VA in intermediate exports absorbed by direct importers as local final goods only after further processing stages"

- EXP 3c "domestic VA in intermediate exports absorbed by direct importers as final goods from third countries"

DVA-GVC Domestic value added that is re-exported by the bilateral importer.

- 1c "domestic VA in intermediate exports absorbed by third countries as domestic final goods after additional processing stages"

- 2c "domestic VA in intermediate exports absorbed by third countries as local final goods"

- 3a "domestic VA in intermediate exports absorbed by third countries as final goods from direct bilateral importers"

- 3b "domestic VA in intermediate exports absorbed by third countries as final goods from direct bilateral importers only after further processing stages"

- EXP 3d "domestic VA in intermediate exports absorbed by third countries as final goods from other third countries 
- EXP 4c "domestic VA in intermediate exports absorbed at home as final goods of a third country"

DVA-REF exports of domestic value added that is absorbed at home.

- EXP 4a "domestic VA in intermediate exports absorbed at home as final goods of the bilateral importers"

- EXP 4b "domestic VA in intermediate exports absorbed at home as final goods of the bilateral importers after further processing stages"

- EXP 5 "domestic VA in intermediate exports absorbed at home as domestic final goods"

FVA-DIR foreign VA in exports that is absorbed by the bilateral importer.

- EXP 7 "foreign VA in exports of final goods"

- EXP 8 "foreign VA in exports of intermediate goods directly absorbed by the importing country"

FVA-GVC foreign VA in exports that is further re-exported by the bilateral importer.

- EXP 9a "foreign VA in exports of intermediate goods re-exported by the bilateral importer"

- EXP 9b "foreign VA in exports of intermediate goods re-exported by a third country"

DCO Double counted exports.

- EXP 9cd "double-counted intermediate exports originally produced abroad"

- EXP 6 "double-counted intermediate exports originally produced at home"

The export data we use in the empirical analysis and in charts have been cleaned for double counted exports. Reflected exports $(D V A-R E F)$ is a negligible fraction of total exports, we discard it in the empirical analysis. 


\section{A.2 Table Appendix}

Table A.2.1: Regression results for gravity model on export flows corrected for financial centres

\begin{tabular}{|c|c|c|c|}
\hline VARIABLES & $\frac{(1)}{E X P}$ & $\frac{(2)}{E X P D V A D I R}$ & $\operatorname{EXP} \frac{(3)}{D V A} G V C$ \\
\hline $\ln \left(Y_{i t}\right)$ & $\begin{array}{l}0.787^{* * *} \\
(0.00641)\end{array}$ & $\begin{array}{l}0.849^{* * *} \\
(0.00679)\end{array}$ & $\begin{array}{l}0.771^{* * *} \\
(0.00568)\end{array}$ \\
\hline $\ln \left(Y_{j t}\right)$ & $\begin{array}{l}0.837^{* * *} \\
(0.00911)\end{array}$ & $\begin{array}{r}0.907^{* * *} \\
(0.0103)\end{array}$ & $\begin{array}{c}0.863^{* * *} \\
(0.0385)\end{array}$ \\
\hline $\ln \left(Y_{w t}\right)$ & $\begin{array}{c}-0.413^{* * *} \\
(0.0322)\end{array}$ & $\begin{array}{c}-0.683^{* * *} \\
(0.0341)\end{array}$ & $\begin{array}{c}-0.828^{* * *} \\
(0.0385)\end{array}$ \\
\hline $\ln \left(\right.$ Distance $\left._{i j}\right)$ & $\begin{array}{c}-0.661^{* * * *} \\
(0.0111)\end{array}$ & $\begin{array}{c}-0.611^{* * *} \\
(0.0104)\end{array}$ & $\begin{array}{l}-0.701^{* * *} \\
(0.00925)\end{array}$ \\
\hline Language $_{i j}$ & $\begin{array}{c}0.109^{* * *} \\
(0.0286)\end{array}$ & $\begin{array}{c}0.158^{* * *} \\
(0.0270)\end{array}$ & $\begin{array}{c}0.265^{* * *} \\
(0.0248)\end{array}$ \\
\hline Border $_{i j}$ & $\begin{array}{c}0.626^{* * *} \\
(0.0386)\end{array}$ & $\begin{array}{c}0.634^{* * *} \\
(0.0374)\end{array}$ & $\begin{array}{c}0.416^{* * *} \\
(0.0300)\end{array}$ \\
\hline$F T A_{i j t}$ & $\begin{array}{c}0.231^{* * *} \\
(0.0498)\end{array}$ & $\begin{array}{c}0.271^{* * *} \\
(0.0428)\end{array}$ & $\begin{array}{c}0.0850^{* *} \\
(0.0388)\end{array}$ \\
\hline$C U_{i j t}$ & $\begin{array}{c}0.0935 \\
(0.0737)\end{array}$ & $\begin{array}{l}0.190^{* *} \\
(0.0742)\end{array}$ & $\begin{array}{l}-0.0673 \\
(0.0746)\end{array}$ \\
\hline$C M_{i j t}$ & $\begin{array}{c}0.0360 \\
(0.0420)\end{array}$ & $\begin{array}{c}0.120^{* * *} \\
(0.0416)\end{array}$ & $\begin{array}{l}0.103^{* *} \\
(0.0488)\end{array}$ \\
\hline$E U_{i j t}$ & $\begin{array}{l}0.0934^{*} \\
(0.0536)\end{array}$ & $\begin{array}{l}0.141^{* *} \\
(0.0609)\end{array}$ & $\begin{array}{c}0.117^{* * *} * \\
(0.0424)\end{array}$ \\
\hline $\ln \left(M R T_{i t}^{\text {out }}\right)$ & $\begin{array}{c}0.456^{* * *} \\
(0.0362)\end{array}$ & $\begin{array}{c}0.546^{* * *} \\
(0.0373)\end{array}$ & $\begin{array}{c}0.696^{* * *} \\
(0.0325)\end{array}$ \\
\hline $\ln \left(M R T_{j t}^{i n}\right)$ & $\begin{array}{c}0.490^{* * *} \\
(0.0394)\end{array}$ & $\begin{array}{c}0.670^{* * *} \\
(0.0428)\end{array}$ & $\begin{array}{c}0.428^{* * *} \\
(0.0361)\end{array}$ \\
\hline $\ln \left(\mathrm{IMP} \mathrm{DVA}-\mathrm{DIR}{ }_{j t}\right)$ & & & $\begin{array}{c}-1.050^{* * *} \\
(0.0978)\end{array}$ \\
\hline $\ln \left(\mathrm{IMP}-\mathrm{DVA}-\mathrm{GVC}_{j t}\right)$ & & & $\begin{array}{c}-0.552^{* * *} \\
(0.0456)\end{array}$ \\
\hline $\ln \left(\right.$ EXP-DVA-DIR $\left._{j t}\right)$ & & & $\begin{array}{c}-1.001^{* * *} \\
(0.123)\end{array}$ \\
\hline $\ln \left(\right.$ EXP-DVA-GVC $\left.{ }_{j t}\right)$ & & & $\begin{array}{c}0.828^{* * *} \\
(0.0982)\end{array}$ \\
\hline $\ln \left(\mathrm{IMP}-\mathrm{FVA}-\mathrm{DIR}_{j t}\right)$ & & & $\begin{array}{c}0.289^{* * *} \\
(0.0857)\end{array}$ \\
\hline $\ln \left(\mathrm{IMP}-\mathrm{FVA}-\mathrm{GVC}_{j t}\right)$ & & & $\begin{array}{l}-0.0738 \\
(0.0560)\end{array}$ \\
\hline $\ln \left(\right.$ EXP-FVA-DIR $\left._{j t}\right)$ & & & $\begin{array}{c}1.967^{* * *} \\
(0.114)\end{array}$ \\
\hline $\ln \left(\right.$ EXP-FVA-GVC $\left.{ }_{j t}\right)$ & & & $\begin{array}{c}-0.397^{* * *} \\
(0.0839)\end{array}$ \\
\hline $\begin{array}{l}\text { Observations } \\
\mathrm{R}^{2}\end{array}$ & 24,600 & 24,600 & $\begin{array}{c}24,600 \\
0959\end{array}$ \\
\hline
\end{tabular}

Robust standard errors in parentheses *** $\mathrm{p}<0.01, * * \mathrm{p}<0.05, * \mathrm{p}<0.1$ 
Table A.2.2: Regression results of gravity model on reported export flows, OLS

\begin{tabular}{|c|c|c|c|}
\hline VARIABLES & $\ln (\mathrm{EXP})$ & $\ln ($ EXP DVA DIR) & $\ln ($ EXP DVA GVC) \\
\hline $\ln \left(Y_{i t}\right)$ & $\begin{array}{c}0.869^{* * *} \\
(0.0188)\end{array}$ & $\begin{array}{c}0.926^{* * *} \\
(0.0184)\end{array}$ & $\begin{array}{c}0.947^{* * *} \\
(0.0197)\end{array}$ \\
\hline $\ln \left(Y_{j t}\right)$ & $\begin{array}{c}0.849 * * * \\
(0.0173)\end{array}$ & $\begin{array}{c}0.902^{* * *} \\
(0.0168)\end{array}$ & $\begin{array}{c}0.258^{* * *} \\
(0.0649)\end{array}$ \\
\hline $\ln \left(Y_{w t}\right)$ & $\begin{array}{c}-0.306^{* * *} \\
(0.0383)\end{array}$ & $\begin{array}{c}-0.694^{* * *} \\
(0.0358)\end{array}$ & $\begin{array}{c}-0.799^{* * *} \\
(0.0634)\end{array}$ \\
\hline $\ln \left(\right.$ Distance $\left._{i j}\right)$ & $\begin{array}{c}-1.005^{* * *} \\
(0.0288)\end{array}$ & $\begin{array}{c}-0.976^{* * *} \\
(0.0283)\end{array}$ & $\begin{array}{c}-0.960^{* * * *} \\
(0.0319)\end{array}$ \\
\hline Language $_{i j}$ & $\begin{array}{c}0.407^{* * *} \\
(0.121)\end{array}$ & $\begin{array}{c}0.407^{* * *} \\
(0.121)\end{array}$ & $\begin{array}{c}0.403^{* * *} \\
(0.132)\end{array}$ \\
\hline Border $_{i j}$ & $\begin{array}{c}0.416^{* * *} \\
(0.101)\end{array}$ & $\begin{array}{c}0.430^{* * *} \\
(0.104)\end{array}$ & $\begin{array}{c}0.560^{* * *} \\
(0.110)\end{array}$ \\
\hline$F T A_{i j t}$ & $\begin{array}{c}-0.204^{* * *} \\
(0.0336)\end{array}$ & $\begin{array}{c}-0.181^{* * *} \\
(0.0320)\end{array}$ & $\begin{array}{c}-0.147^{* * *} \\
(0.0356)\end{array}$ \\
\hline$C U_{i j t}$ & $\begin{array}{l}-0.0299 \\
(0.0672)\end{array}$ & $\begin{array}{l}-0.0259 \\
(0.0668)\end{array}$ & $\begin{array}{c}0.0113 \\
(0.0765)\end{array}$ \\
\hline$C M_{i j t}$ & $\begin{array}{c}0.0410 \\
(0.0253)\end{array}$ & $\begin{array}{c}0.0364 \\
(0.0240)\end{array}$ & $\begin{array}{c}0.0324 \\
(0.0255)\end{array}$ \\
\hline$E U_{i j t}$ & $\begin{array}{c}0.130^{* * *} \\
(0.0408)\end{array}$ & $\begin{array}{l}0.150^{* * *} \\
(0.0418)\end{array}$ & $\begin{array}{c}0.115^{* * *} \\
(0.0412)\end{array}$ \\
\hline $\ln \left(M R T_{\text {it }}^{\text {out }}\right)$ & $\begin{array}{c}-0.261^{* * *} \\
(0.0893)\end{array}$ & $\begin{array}{c}-0.106 \\
(0.0861)\end{array}$ & $\begin{array}{l}-0.149 \\
(0.102)\end{array}$ \\
\hline $\ln \left(M R T_{j t}^{i n}\right)$ & $\begin{array}{l}0.0745 \\
(0.116)\end{array}$ & $\begin{array}{c}0.372^{* * *} \\
(0.114)\end{array}$ & $\begin{array}{c}0.754^{* * *} \\
(0.148)\end{array}$ \\
\hline $\ln \left(\mathrm{IMP} \mathrm{DVA}-\mathrm{DIR}_{j t}\right)$ & & & $\begin{array}{l}-0.246 \\
(0.163)\end{array}$ \\
\hline $\ln \left(\mathrm{IMP}-\mathrm{DVA}-\mathrm{GVC}_{j t}\right)$ & & & $\begin{array}{c}0.338^{* * *} \\
(0.109)\end{array}$ \\
\hline $\ln \left(\right.$ EXP-DVA-DIRP $\left._{j t}\right)$ & & & $\begin{array}{c}0.457^{* * *} \\
(0.143)\end{array}$ \\
\hline $\ln \left(\right.$ EXP-DVA-GVC $\left.{ }_{j t}\right)$ & & & $\begin{array}{c}-0.373^{* * * *} \\
(0.120)\end{array}$ \\
\hline $\ln \left(\mathrm{IMP} \mathrm{FVA}-\mathrm{DIR}_{j t}\right)$ & & & $\begin{array}{l}0.0271 \\
(0.158)\end{array}$ \\
\hline $\ln \left(\mathrm{IMP}-\mathrm{FVA}-\mathrm{GVC}_{j t}\right)$ & & & $\begin{array}{l}0.237^{*} \\
(0.131)\end{array}$ \\
\hline $\ln \left(\mathrm{EXP} \mathrm{FVA}-\mathrm{DIR}{ }_{j t}\right)$ & & & $\begin{array}{l}0.0127 \\
(0.127)\end{array}$ \\
\hline $\ln \left(\right.$ EXP-FVA-GVC $\left.{ }_{j t}\right)$ & & & $\begin{array}{l}0.266^{* *} \\
(0.114)\end{array}$ \\
\hline Observations & 24,600 & 24,600 & 24,600 \\
\hline $\mathrm{R}^{2}$ & 0.827 & 0.845 & 0.817 \\
\hline
\end{tabular}

Robust standard errors in parentheses ${ }^{* * *} \mathrm{p}<0.01,{ }^{* *} \mathrm{p}<0.05,{ }^{*} \mathrm{p}<0.1$ 
Table A.2.3: Regression results for gravity model on reported export flows, fixed effects

\begin{tabular}{|c|c|c|c|}
\hline VARIABLES & $\begin{array}{c}(1) \\
\text { EXP }\end{array}$ & $\begin{array}{c}(2) \\
\text { EXP DVA DIR }\end{array}$ & $\begin{array}{c}(3) \\
\text { EXP DVA GVC }\end{array}$ \\
\hline $\ln \left(Y_{i t}\right)$ & $\begin{array}{c}0.589^{* * *} \\
(0.0195)\end{array}$ & $\begin{array}{c}0.668^{* * *} \\
(0.0204)\end{array}$ & $\begin{array}{c}0.609 * * * \\
(0.0191)\end{array}$ \\
\hline $\ln \left(Y_{j t}\right)$ & $\begin{array}{c}0.711^{* * *} \\
(0.0189)\end{array}$ & $\begin{array}{c}0.808^{* * *} \\
(0.0183)\end{array}$ & $\begin{array}{c}0.388^{* * *} \\
(0.0544)\end{array}$ \\
\hline $\ln \left(Y_{w t}\right)$ & $\begin{array}{c}-0.119^{* * *} \\
(0.0239)\end{array}$ & $\begin{array}{c}-0.461^{* * *} \\
(0.0241)\end{array}$ & $\begin{array}{c}-0.487^{* * *} \\
(0.0490)\end{array}$ \\
\hline $\ln \left(\right.$ Distance $\left._{i j}\right)$ & $\begin{array}{c}-0.977^{* * *} \\
(0.0154)\end{array}$ & $\begin{array}{c}-1.025^{* * *} \\
(0.0205)\end{array}$ & $\begin{array}{c}-0.874^{* * *} \\
(0.0192)\end{array}$ \\
\hline Language $_{i j}$ & $\begin{array}{c}-0.311^{*} \\
(0.173)\end{array}$ & $\begin{array}{c}-0.603^{* * *} \\
(0.170)\end{array}$ & $\begin{array}{c}-0.718^{* * *} \\
(0.220)\end{array}$ \\
\hline Border $_{i j}$ & $\begin{array}{l}2.496^{* * *} \\
(0.0646)\end{array}$ & $\begin{array}{c}2.690^{* * *} \\
(0.0736)\end{array}$ & $\begin{array}{c}2.303^{* * *} \\
(0.128)\end{array}$ \\
\hline$F T A_{i j t}$ & $\begin{array}{l}-0.00219 \\
(0.0281)\end{array}$ & $\begin{array}{l}-0.0203 \\
(0.0249)\end{array}$ & $\begin{array}{c}-0.0759^{* * *} \\
(0.0169)\end{array}$ \\
\hline$C U_{i j t}$ & $\begin{array}{c}-0.101^{* * *} \\
(0.0289)\end{array}$ & $\begin{array}{l}-0.0364 \\
(0.0277)\end{array}$ & $\begin{array}{c}-0.0480^{*} \\
(0.0285)\end{array}$ \\
\hline$C M_{i j t}$ & $\begin{array}{l}0.0220^{*} \\
(0.0132)\end{array}$ & $\begin{array}{c}0.0158 \\
(0.0142)\end{array}$ & $\begin{array}{c}0.0445^{* * *} \\
(0.0161)\end{array}$ \\
\hline$E U_{i j t}$ & $\begin{array}{c}0.0574^{* * *} \\
(0.0135)\end{array}$ & $\begin{array}{c}0.116^{* * *} \\
(0.0132)\end{array}$ & $\begin{array}{c}0.105^{* * *} \\
(0.0138)\end{array}$ \\
\hline $\ln \left(\mathrm{IMP} \mathrm{DVA}-\mathrm{DIR}{ }_{j t}\right)$ & & & $\begin{array}{c}-0.724^{* * *} \\
(0.136)\end{array}$ \\
\hline $\ln \left(\mathrm{IMP}-\mathrm{DVA}-\mathrm{GVC}_{j t}\right)$ & & & $\begin{array}{l}0.0238 \\
(0.101)\end{array}$ \\
\hline $\ln \left(\mathrm{EXP} \mathrm{DVA}-\mathrm{DIRP}{ }_{j t}\right)$ & & & $\begin{array}{c}-0.347^{* * *} \\
(0.111)\end{array}$ \\
\hline $\ln \left(\right.$ EXP-DVA-GVC $\left.{ }_{j t}\right)$ & & & $\begin{array}{c}0.174^{*} \\
(0.0943)\end{array}$ \\
\hline $\ln \left(\mathrm{IMP}-\mathrm{FVA}-\mathrm{DIR}{ }_{j t}\right)$ & & & $\begin{array}{c}0.429^{* * *} \\
(0.134)\end{array}$ \\
\hline $\ln \left(\mathrm{IMP}-\mathrm{FVA}-\mathrm{GVC}_{j t}\right)$ & & & $\begin{array}{c}0.149 \\
(0.110)\end{array}$ \\
\hline $\ln \left(\right.$ EXP-FVA-DIR $\left._{j t}\right)$ & & & $\begin{array}{c}0.863^{* * *} \\
(0.0942)\end{array}$ \\
\hline $\ln \left(\mathrm{EXP}-\mathrm{FVA}-\mathrm{GVC}_{j t}\right)$ & & & $\begin{array}{c}-0.196 * * * \\
(0.0654)\end{array}$ \\
\hline Observations & 24,600 & 24,600 & 24,600 \\
\hline $\mathrm{R}^{2}$ & 0.985 & 0.987 & 0.972 \\
\hline
\end{tabular}

Note: Estimated with importer and exporter fixed Robust standard errors in parentheses *** $\mathrm{p}<0.01,{ }^{*} * \mathrm{p}<0.05,{ }^{*} \mathrm{p}<0.1$ 
Table A.2.4: Regression results of gravity model on reported export flows, sigma=2

\begin{tabular}{|c|c|c|c|}
\hline VARIABLES & $\begin{array}{c}(1) \\
\text { EXP }\end{array}$ & $\begin{array}{c}(2) \\
\text { DVA DIR }\end{array}$ & $\begin{array}{c}(3) \\
\text { DVA GVC }\end{array}$ \\
\hline $\ln \left(Y_{i t}\right)$ & $\begin{array}{l}0.759^{* * *} \\
(0.00682)\end{array}$ & $\begin{array}{l}0.826^{* * *} \\
(0.00726)\end{array}$ & $\begin{array}{l}0.742^{* * *} \\
(0.00683)\end{array}$ \\
\hline $\ln \left(Y_{j t}\right)$ & $\begin{array}{c}0.775^{* * *} \\
(0.00825)\end{array}$ & $\begin{array}{c}0.842^{* * *} \\
(0.00895)\end{array}$ & $\begin{array}{c}0.790^{* * *} \\
(0.0475)\end{array}$ \\
\hline $\ln \left(Y_{w t}\right)$ & $\begin{array}{c}-0.368^{* * *} \\
(0.0322)\end{array}$ & $\begin{array}{c}-0.644^{* * *} \\
(0.0333)\end{array}$ & $\begin{array}{c}-0.824^{* * *} \\
(0.0450)\end{array}$ \\
\hline $\ln \left(\right.$ Distance $\left._{i j}\right)$ & $\begin{array}{c}-0.652^{* * *} \\
(0.0107)\end{array}$ & $\begin{array}{c}-0.596^{* * *} \\
(0.0102)\end{array}$ & $\begin{array}{c}-0.675^{* * *} \\
(0.0102)\end{array}$ \\
\hline Language $_{i j}$ & $\begin{array}{c}0.179^{* * *} * \\
(0.0306)\end{array}$ & $\begin{array}{c}0.171^{* * *} \\
(0.0266)\end{array}$ & $\begin{array}{c}0.340^{* * *} * \\
(0.0471)\end{array}$ \\
\hline Border $_{i j}$ & $\begin{array}{c}0.534^{* * *} * \\
(0.0404)\end{array}$ & $\begin{array}{c}0.568^{* * *} \\
(0.0385)\end{array}$ & $\begin{array}{c}0.290^{* * *} * \\
(0.0350)\end{array}$ \\
\hline$F T A_{i j t}$ & $\begin{array}{c}0.191^{* * *} \\
(0.0549)\end{array}$ & $\begin{array}{c}0.216^{* * *} \\
(0.0479)\end{array}$ & $\begin{array}{l}0.0818^{*} \\
(0.0445)\end{array}$ \\
\hline$C U_{i j t}$ & $\begin{array}{c}0.0401 \\
(0.0720)\end{array}$ & $\begin{array}{l}0.161^{* *} \\
(0.0734)\end{array}$ & $\begin{array}{c}-0.104 \\
(0.0729)\end{array}$ \\
\hline$C M_{i j t}$ & $\begin{array}{c}0.0845^{* *} \\
(0.0403)\end{array}$ & $\begin{array}{c}0.190 * * * \\
(0.0402)\end{array}$ & $\begin{array}{c}0.161^{* * *} \\
(0.0479)\end{array}$ \\
\hline$E U_{i j t}$ & $\begin{array}{c}0.0629 \\
(0.0558)\end{array}$ & $\begin{array}{c}0.0995 \\
(0.0623)\end{array}$ & $\begin{array}{c}0.0565 \\
(0.0471)\end{array}$ \\
\hline $\ln \left(M R T_{i t}^{\text {out }}\right)$ & $\begin{array}{c}0.486^{* * *} \\
(0.0487)\end{array}$ & $\begin{array}{c}0.507^{* * *} \\
(0.0472)\end{array}$ & $\begin{array}{c}0.764^{* * *} \\
(0.0593)\end{array}$ \\
\hline $\ln \left(M R T_{j t}^{i n}\right)$ & $\begin{array}{c}0.709^{* * *} * \\
(0.0543)\end{array}$ & $\begin{array}{c}0.909 * * * \\
(0.0552)\end{array}$ & $\begin{array}{c}0.470^{* * *} * \\
(0.0747)\end{array}$ \\
\hline $\ln \left(\mathrm{IMP} \mathrm{DVA}-\mathrm{DIR}_{j t}\right)$ & & & $\begin{array}{c}-1.507^{* * *} \\
(0.149)\end{array}$ \\
\hline $\ln \left(\mathrm{IMP}-\mathrm{DVA}-\mathrm{GVC}_{j t}\right)$ & & & $\begin{array}{c}-0.352^{* * * *} \\
(0.0682)\end{array}$ \\
\hline $\ln \left(\right.$ EXP-DVA-DIRP $\left._{j t}\right)$ & & & $\begin{array}{c}-1.076^{* * *} \\
(0.153)\end{array}$ \\
\hline $\ln \left(\right.$ EXP-DVA-GVC $\left.{ }_{j t}\right)$ & & & $\begin{array}{c}0.858^{* * *} \\
(0.125)\end{array}$ \\
\hline $\ln \left(\mathrm{IMP} \mathrm{FVA}-\mathrm{DIR} \mathrm{R}_{j t}\right)$ & & & $\begin{array}{c}0.793^{* * *} \\
(0.141)\end{array}$ \\
\hline $\ln \left(\mathrm{IMP}-\mathrm{FVA}-\mathrm{GVC}_{j t}\right)$ & & & $\begin{array}{c}-0.561^{* * *} \\
(0.0968)\end{array}$ \\
\hline $\ln \left(\right.$ EXP-FVA-DIR $\left.{ }_{j t}\right)$ & & & $\begin{array}{c}2.312^{* * *} \\
(0.151)\end{array}$ \\
\hline $\ln \left(\right.$ EXP-FVA-GVC $\left.{ }_{j t}\right)$ & & & $\begin{array}{c}-0.411^{* * *} * \\
(0.104)\end{array}$ \\
\hline Observations & 24,600 & 24,600 & 24,600 \\
\hline $\mathrm{R}^{2}$ & 0.798 & 0.814 & 0.742 \\
\hline
\end{tabular}

Note: Multilateral resistance terms when sigma is set to 2 . Robust standard errors in parentheses *** $\mathrm{p}<0.01,{ }^{* *} \mathrm{p}<0.05,{ }^{*} \mathrm{p}<0.1$ 
Table A.2.5: Regression results of gravity model on reported export flows, sigma $=4$

\begin{tabular}{|c|c|c|c|}
\hline VARIABLES & $\begin{array}{l}(1) \\
\text { EXP }\end{array}$ & $\begin{array}{c}(2) \\
\text { DVA DIR }\end{array}$ & $\begin{array}{c}(3) \\
\text { DVA GVC }\end{array}$ \\
\hline $\ln \left(Y_{i t}\right)$ & $\begin{array}{l}0.779^{* * *} \\
(0.00673)\end{array}$ & $\begin{array}{l}0.847^{* * *} \\
(0.00688)\end{array}$ & $\begin{array}{l}0.778^{* * *} \\
(0.00736)\end{array}$ \\
\hline $\ln \left(Y_{j t}\right)$ & $\begin{array}{l}0.820^{* * *} \\
(0.00921)\end{array}$ & $\begin{array}{c}0.910^{* * *} \\
(0.0100)\end{array}$ & $\begin{array}{l}0.889^{* * *} \\
(0.0461)\end{array}$ \\
\hline $\ln \left(Y_{w t}\right)$ & $\begin{array}{c}-0.347^{* * *} \\
(0.0341)\end{array}$ & $\begin{array}{c}-0.654^{* * *} \\
(0.0351)\end{array}$ & $\begin{array}{c}-0.826^{* * * *} \\
(0.0463)\end{array}$ \\
\hline $\ln \left(\right.$ Distance $\left._{i j}\right)$ & $\begin{array}{c}-0.629 * * * \\
(0.0119)\end{array}$ & $\begin{array}{c}-0.589^{* * *} * \\
(0.0108)\end{array}$ & $\begin{array}{c}-0.660^{* * *} * \\
(0.0105)\end{array}$ \\
\hline Language $_{i j}$ & $\begin{array}{c}0.140^{* * *} \\
(0.0325)\end{array}$ & $\begin{array}{c}0.172^{* * *} \\
(0.0285)\end{array}$ & $\begin{array}{c}0.326^{* * *} \\
(0.0471)\end{array}$ \\
\hline Border $_{i j}$ & $\begin{array}{c}0.548^{* * *} \\
(0.0418)\end{array}$ & $\begin{array}{c}0.584^{* * *} \\
(0.0395)\end{array}$ & $\begin{array}{c}0.303^{* * *} \\
(0.0353)\end{array}$ \\
\hline$F T A_{i j t}$ & $\begin{array}{c}0.218^{* * *} \\
(0.0562)\end{array}$ & $\begin{array}{c}0.257^{* * *} \\
(0.0474)\end{array}$ & $\begin{array}{c}0.0895^{* *} \\
(0.0439)\end{array}$ \\
\hline$C U_{i j t}$ & $\begin{array}{c}0.0601 \\
(0.0724)\end{array}$ & $\begin{array}{l}0.160^{* *} \\
(0.0745)\end{array}$ & $\begin{array}{c}-0.101 \\
(0.0730)\end{array}$ \\
\hline$C M_{i j t}$ & $\begin{array}{c}0.0514 \\
(0.0433)\end{array}$ & $\begin{array}{c}0.122^{* * *} \\
(0.0432)\end{array}$ & $\begin{array}{c}0.165^{* * *} \\
(0.0493)\end{array}$ \\
\hline$E U_{i j t}$ & $\begin{array}{c}0.0663 \\
(0.0567)\end{array}$ & $\begin{array}{l}0.123^{* *} \\
(0.0623)\end{array}$ & $\begin{array}{l}0.0903^{*} \\
(0.0470)\end{array}$ \\
\hline $\ln \left(M R T_{i t}^{\text {out }}\right)$ & $\begin{array}{c}0.234^{* * *} \\
(0.0308)\end{array}$ & $\begin{array}{c}0.353^{* * *} \\
(0.0320)\end{array}$ & $\begin{array}{c}0.399^{* * *} \\
(0.0282)\end{array}$ \\
\hline $\ln \left(M R T_{j t}^{i n}\right)$ & $\begin{array}{c}0.194^{* * *} \\
(0.0320)\end{array}$ & $\begin{array}{c}0.389^{* * *} \\
(0.0338)\end{array}$ & $\begin{array}{c}0.146^{* * *} \\
(0.0402)\end{array}$ \\
\hline $\ln \left(\mathrm{IMP} \mathrm{DVA}-\mathrm{DIR}_{j t}\right)$ & & & $\begin{array}{c}-1.672^{* * *} \\
(0.141)\end{array}$ \\
\hline $\ln \left(\mathrm{IMP}-\mathrm{DVA}-\mathrm{GVC}_{j t}\right)$ & & & $\begin{array}{c}-0.338^{* * * *} \\
(0.0669)\end{array}$ \\
\hline $\ln \left(\right.$ EXP-DVA-DIRP $\left._{j t}\right)$ & & & $\begin{array}{c}-1.121^{* * * *} \\
(0.156)\end{array}$ \\
\hline $\ln \left(\right.$ EXP-DVA-GVC $\left.{ }_{j t}\right)$ & & & $\begin{array}{c}0.875^{* * *} \\
(0.128)\end{array}$ \\
\hline $\ln \left(\mathrm{IMP} \mathrm{FVA}-\mathrm{DIR} \mathrm{R}_{j t}\right)$ & & & $\begin{array}{c}0.865^{* * *} \\
(0.133)\end{array}$ \\
\hline $\ln \left(\mathrm{IMP}-\mathrm{FVA}-\mathrm{GVC}_{j t}\right)$ & & & $\begin{array}{c}-0.571^{* * *} \\
(0.0928)\end{array}$ \\
\hline $\ln \left(\right.$ EXP-FVA-DIR $\left._{j t}\right)$ & & & $\begin{array}{c}2.304^{* * *} \\
(0.154)\end{array}$ \\
\hline $\ln \left(\right.$ EXP-FVA-GVC $\left.{ }_{j t}\right)$ & & & $\begin{array}{c}-0.375^{* * *} \\
(0.107)\end{array}$ \\
\hline Observations & 24,600 & 24,600 & 24,600 \\
\hline $\mathrm{R}^{2}$ & 0.788 & 0.807 & 0.736 \\
\hline
\end{tabular}

Note: Multilateral resistance terms when sigma is set to 4 . Robust standard errors in parentheses *** $\mathrm{p}<0.01,{ }^{* *} \mathrm{p}<0.05,{ }^{*} \mathrm{p}<0.1$ 


\section{A.3 Trade balance and export fit}

Table A.3.1: Trade balance fit, reported trade balance on predicted trade balance

\begin{tabular}{|c|c|c|c|c|}
\hline VARIABLES & $\begin{array}{l}(1) \\
\mathrm{TB}\end{array}$ & $\begin{array}{c}(2) \\
\text { TB DVA DIR }\end{array}$ & $\begin{array}{c}(3) \\
\text { TB DVA GVC }\end{array}$ & $\begin{array}{c}(4) \\
\text { TB FVA }\end{array}$ \\
\hline$\widehat{T B}$ & $\begin{array}{l}0.310^{*} \\
(0.182)\end{array}$ & & & \\
\hline$\widehat{T B}$ DVA DIR & & $\begin{array}{c}1.026^{* * *} \\
(0.158)\end{array}$ & & \\
\hline$\widehat{T B}$ DVA GVC & & & $\begin{array}{l}0.873^{* * *} \\
(0.0669)\end{array}$ & \\
\hline$\widehat{T B} \mathrm{FVA}$ & & & & $\begin{array}{l}1.003^{* * *} \\
(0.0987)\end{array}$ \\
\hline Observations & 24,600 & 24,600 & 24,600 & 24,600 \\
\hline $\mathrm{R}^{2}$ & 0.155 & 0.303 & 0.496 & 0.620 \\
\hline
\end{tabular}

Table A.3.2: Trade balance fit, reported trade balance on predicted trade balance. Nonfinancial centres

\begin{tabular}{|c|c|c|c|c|}
\hline VARIABLES & $\begin{array}{l}(1) \\
\mathrm{TB}\end{array}$ & $\begin{array}{c}(2) \\
\text { TB DVA DIR } \\
\end{array}$ & $\begin{array}{c}(3) \\
\text { TB DVA GVC }\end{array}$ & $\begin{array}{c}(4) \\
\text { TB FVA }\end{array}$ \\
\hline$\widehat{T B}$ & $\begin{array}{c}0.234 \\
(0.205)\end{array}$ & & & \\
\hline$\widehat{T B}$ DVA DIR & & $\begin{array}{c}1.051^{* * *} \\
(0.172)\end{array}$ & & \\
\hline$\widehat{T B}$ DVA GVC & & & $\begin{array}{l}0.779^{* * *} \\
(0.00624)\end{array}$ & \\
\hline$\widehat{T B} \mathrm{FVA}$ & & & & $\begin{array}{c}0.995^{* * *} \\
(0.147)\end{array}$ \\
\hline Observations & 17,850 & 17,850 & 17,850 & 17,850 \\
\hline $\mathrm{R}^{2}$ & 0.155 & 0.319 & 0.588 & 0.594 \\
\hline
\end{tabular}


Table A.3.3: Export fit, reported export flows on predicted export flows

\begin{tabular}{|c|c|c|c|c|}
\hline VARIABLES & $\begin{array}{c}(1) \\
\text { EXP }\end{array}$ & $\begin{array}{c}(2) \\
\text { EXP DVA DIR }\end{array}$ & $\begin{array}{c}(3) \\
\text { EXP DVA GVC }\end{array}$ & $\begin{array}{c}(4) \\
\text { EXP FVA }\end{array}$ \\
\hline$\widehat{E X P}$ & $\begin{array}{l}0.913^{* * *} \\
(0.0765)\end{array}$ & & & \\
\hline$\widehat{E X P}$ DVA DIR & & $\begin{array}{l}0.901^{* * *} \\
(0.1000)\end{array}$ & & \\
\hline$\widehat{E X P}$ DVA GVC & & & $\begin{array}{l}0.939^{* * *} \\
(0.0508)\end{array}$ & \\
\hline$\widehat{E X P}$ FVA & & & & $\begin{array}{c}0.971^{* * *} \\
(0.0721)\end{array}$ \\
\hline Observations & 24,600 & 24,600 & 24,600 & 24,600 \\
\hline $\mathrm{R}^{2}$ & 0.791 & 0.792 & 0.747 & 0.769 \\
\hline
\end{tabular}

Robust standard errors in parentheses *** $\mathrm{p}<0.01,{ }^{* *} \mathrm{p}<0.05,{ }^{*} \mathrm{p}<0.1$ 


\section{A.4 Figures}

Figure A.4.1: The value added representation of the bilateral trade balance for Ireland

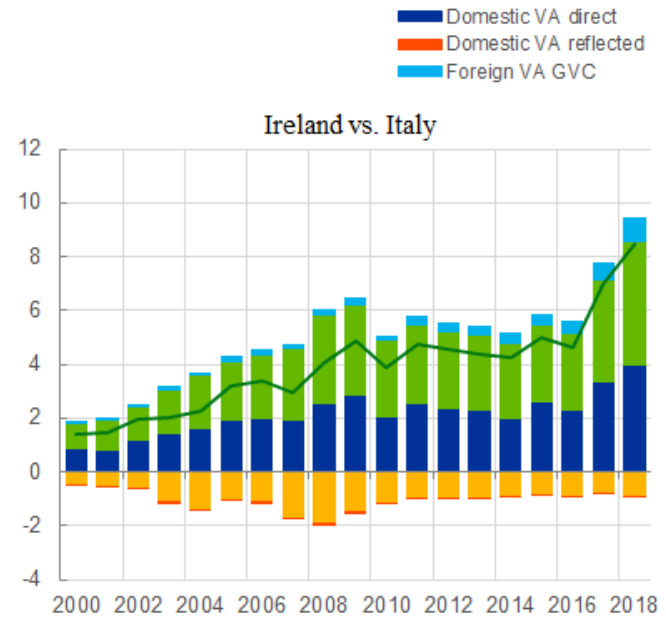

$$
\begin{aligned}
& \text { Domestic VA GVC } \\
& \text { Foreign VA direct } \\
& \text { trade balance }
\end{aligned}
$$
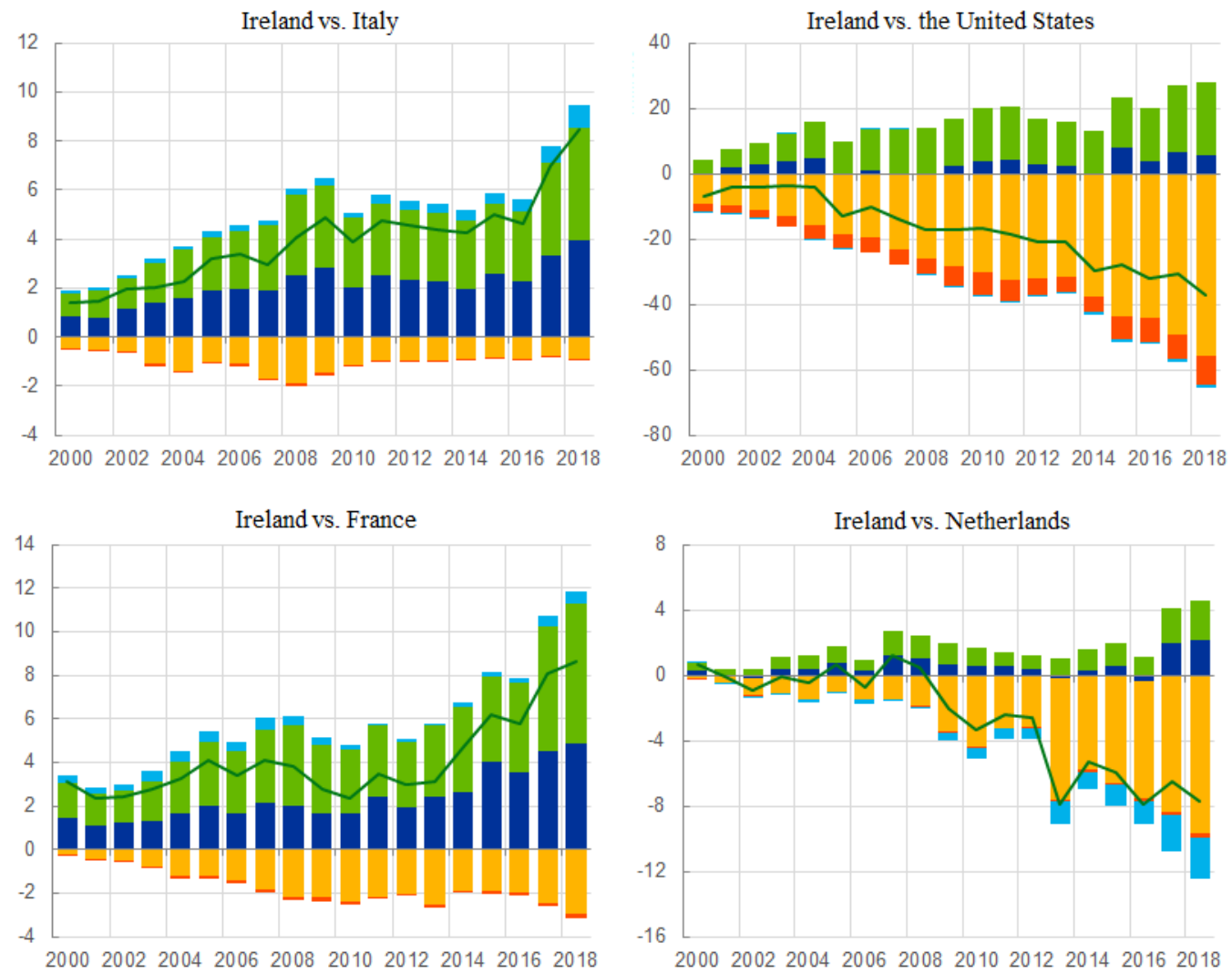

Note: vertical axes expressed in billions USD.

Source: authors' computations based on WIOD and ADB MRIO tables. 
Figure A.4.2: The value added representation of the bilateral trade balance for Belgium
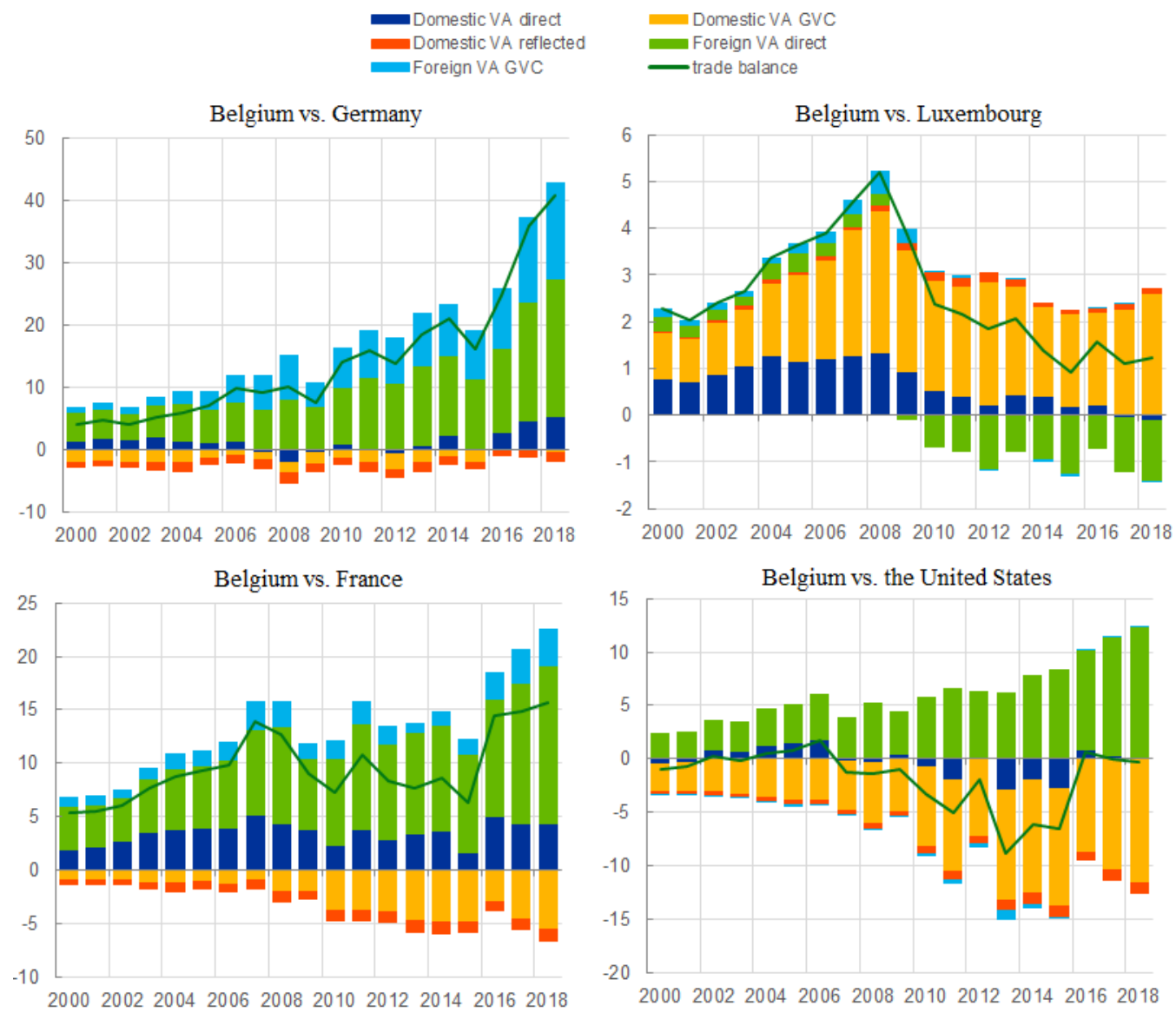

Note: vertical axes expressed in billions USD.

Source: authors' computations based on WIOD and ADB MRIO tables. 
Figure A.4.3: The value added representation of the bilateral trade balance for Netherlands
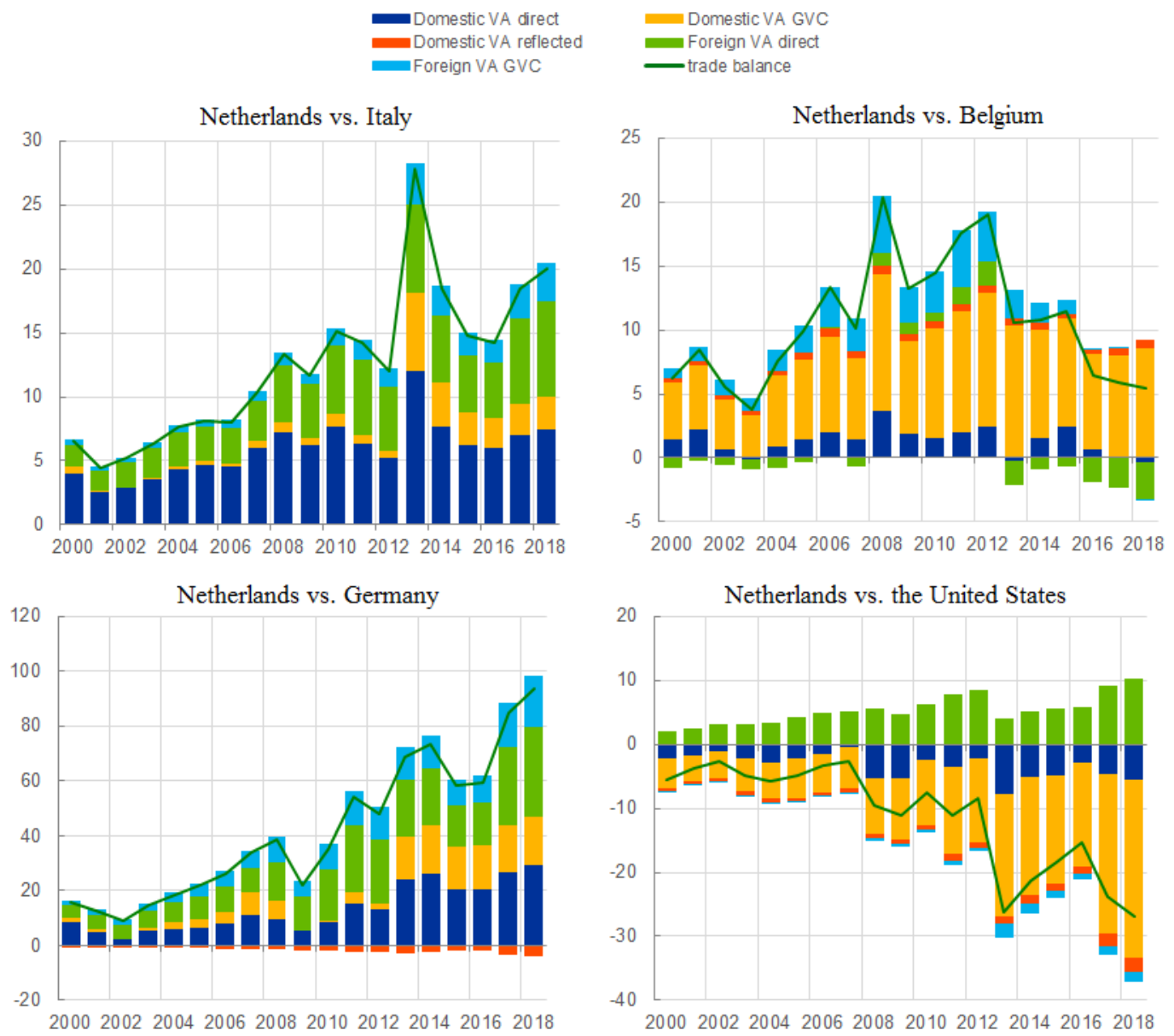

Note: vertical axes expressed in billions USD.

Source: authors' computations based on WIOD and ADB MRIO tables. 


\section{A.5 Figures}

Figure A.5.1: Euro Area trade balance and profit shifting percentage of GDP

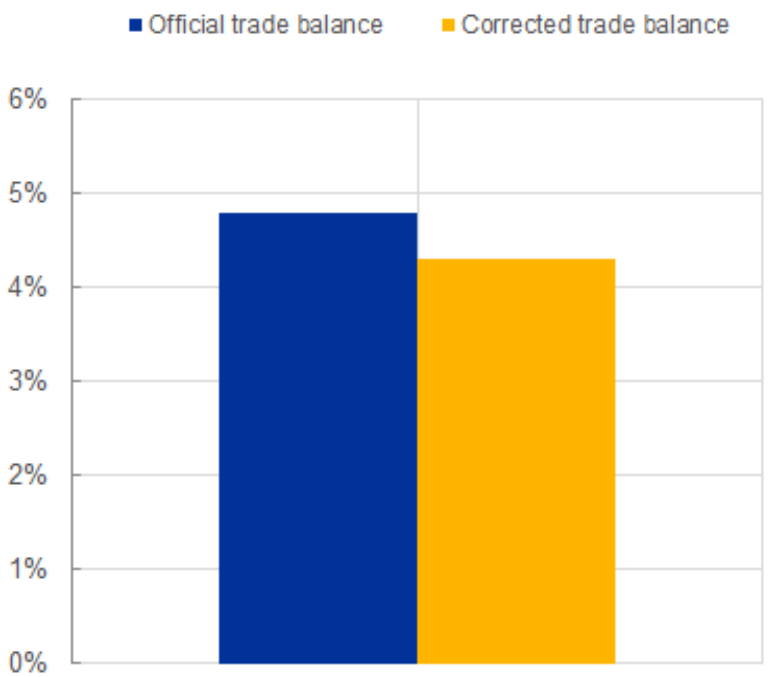

Note: Cyprus, Malta and Lithuania are excluded. Source: "the Missing Profits of Nations". (Sep 2019). Authours: Torslov, T., Wier, L., Zucman, G. and the authors' calculations

Figure A.5.2: Trade balances and profit shifting effects

$$
\text { percentage of } G D P
$$

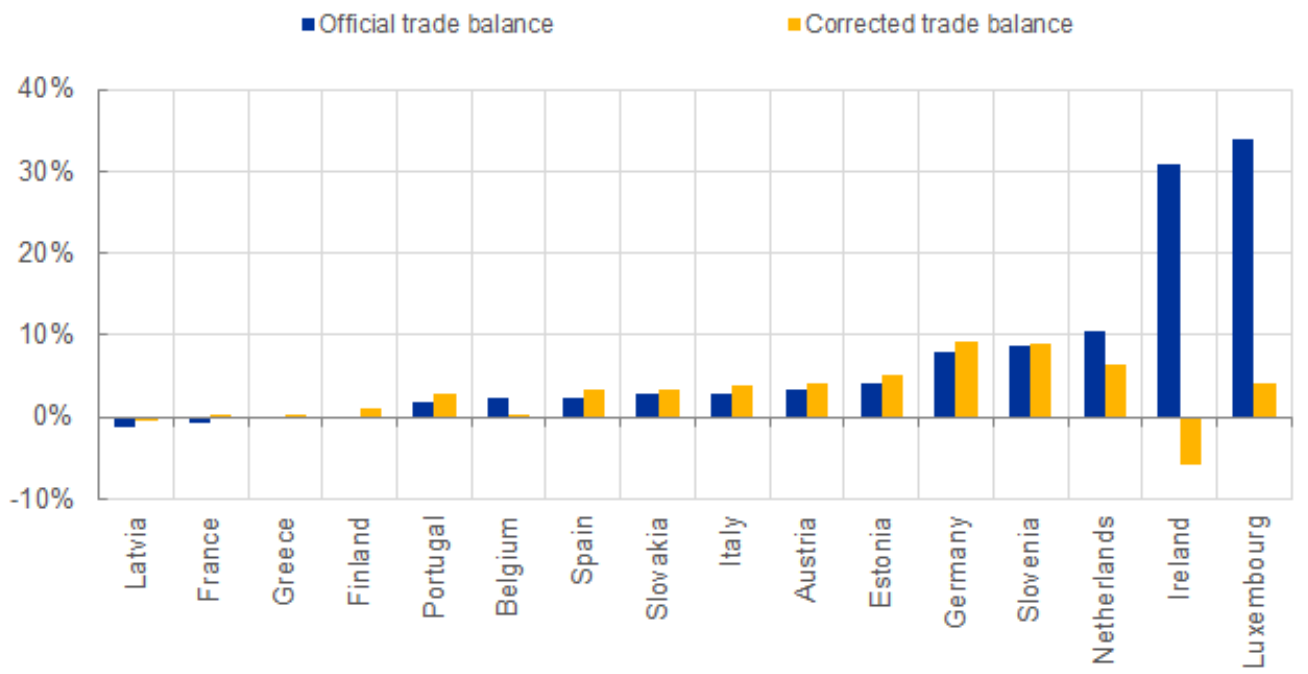

Note: Cyprus, Malta and Lithuania are excluded. Source: "the Missing Profits of Nations". (Sep 2019). Authours: Torslov, T., Wier, L., Zucman, G. and the authors' calculations 


\section{A.6 Figures}

Figure A.6.1: reported and corrected trade balances

- - Corrected trade balance

the United States

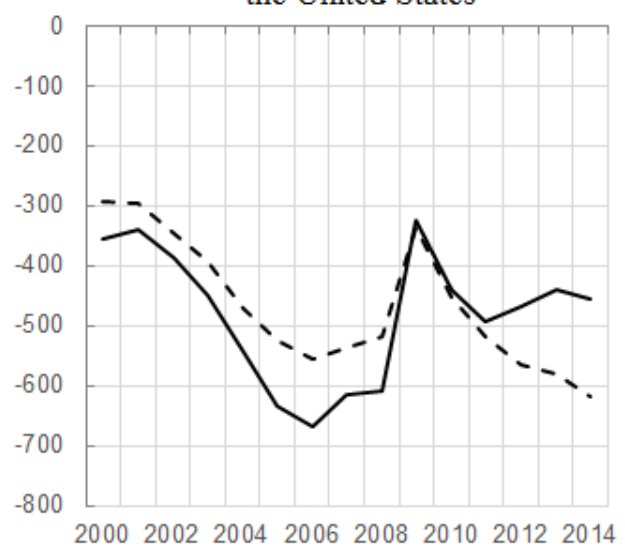

China

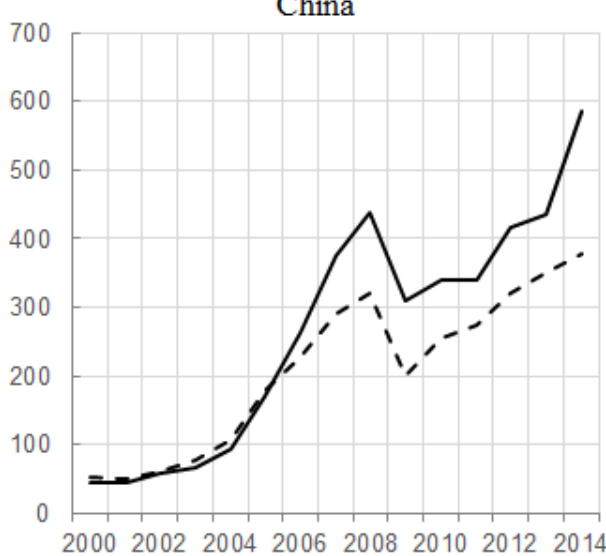

Germany

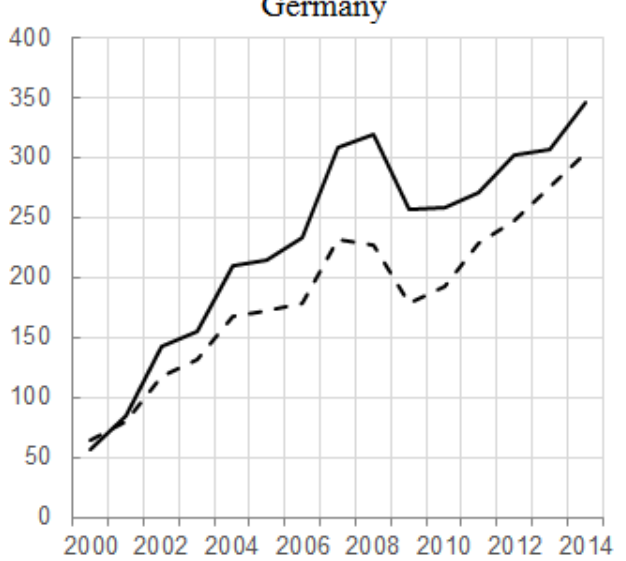

_ Reported trade balance

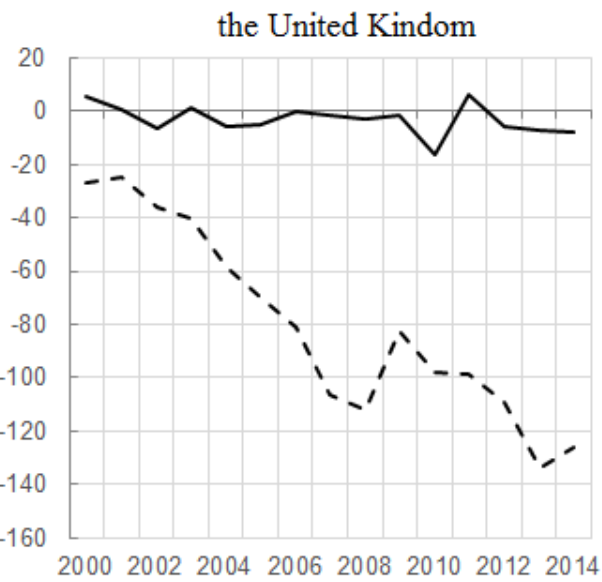

Japan

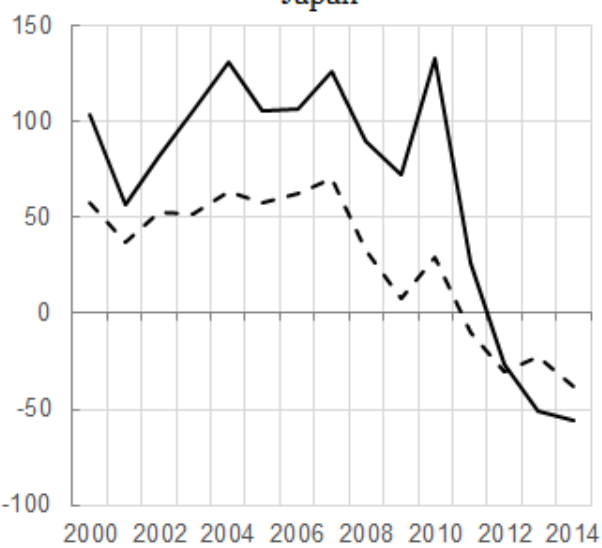

Italy

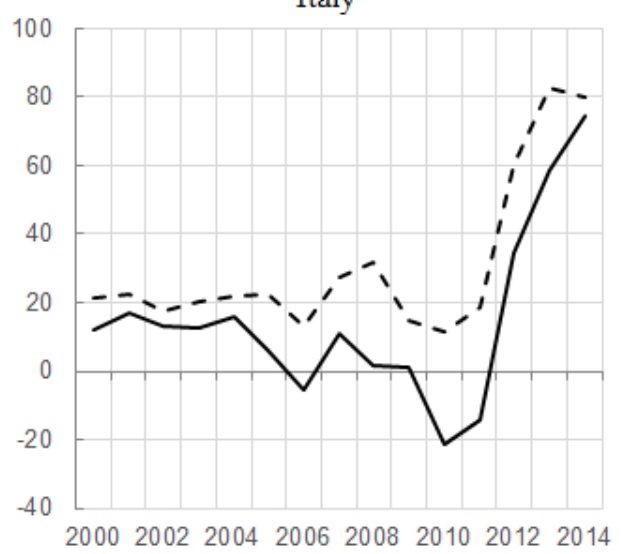



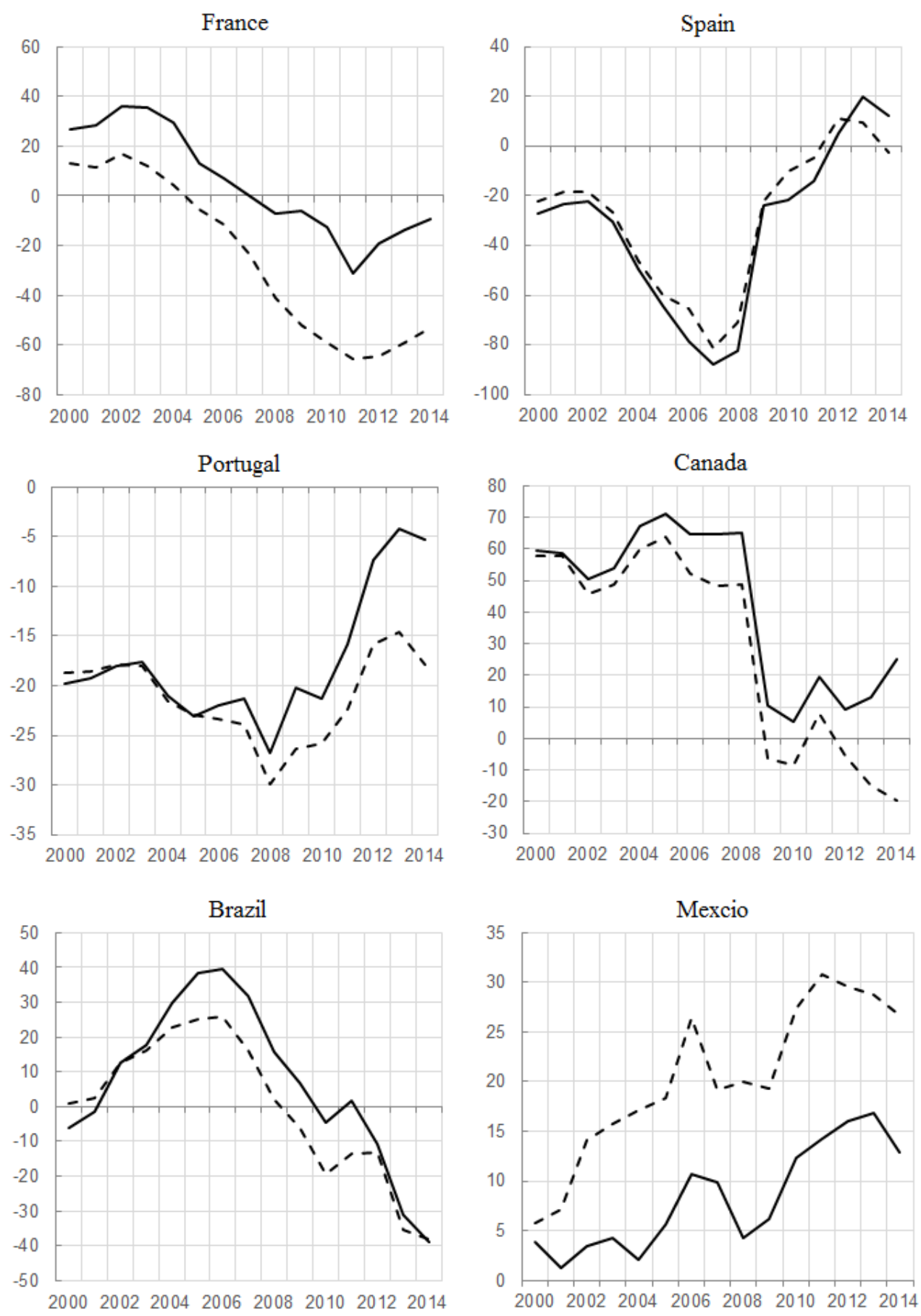

Note: vertical axes expressed in billions USD.

Source: authors' computations based on WIOD tables. 
Virginia Di Nino

Euro Area External Sector and Euro Adoption Division Directorate General Economics - ECB

BIS - ECB - BoP

Lisbon $17-02-2020$

Bridging measurement challenges and analytical needs of external statistics: evolution or revolution?

\section{WHAT VALUE ADDED IN TRADE BALANCES? \\ THE CASE OF EURO AREA FINANCIAL CENTRES}

\author{
Virginia Di Nino \\ Anna Ekstam
}

Disclaimer: the views expressed in this work are those of the authors and do not necessarily reflect those of the ECB. 
MOTIVATION: Transfer Pricing and Profit Shifting practices plague BOP statistics and our understanding of key economic phenomena

> Large Trade Surpluses maintained by tax havens Zucman et al. (2017, 2019), Dowd, Landefeld and Moore(2017), Flaaen et al. (2017), Dharmapala (2019).

$>$ WIOD use "cum grano salis" Timmer et al. (2015)

\section{STYLIZED FACTS: TPPS revealed in Value Added trade}

> Trade Balance of euro area financial centres through value added lenses

> Participation and positioning of euro area financial centres in GVC

\section{HOW to IMPROVE?}

$>$ Apply the gravity workhorse

$>$ Estimate adjusted Trade Balances for financial centres 


\section{Measuring trade in value added}

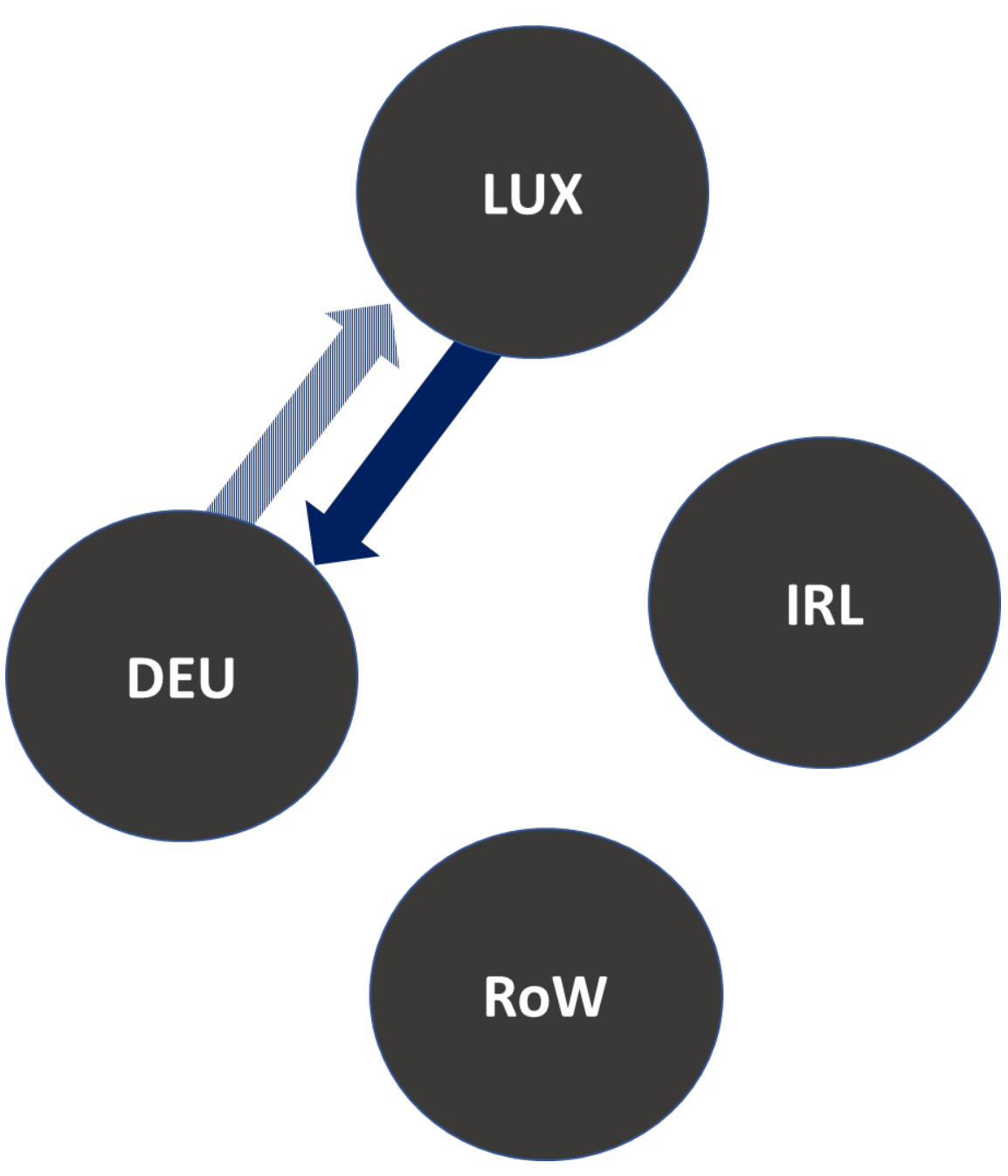

Domestic value added absorbed by the direct importer (DVA direct)

See Borin Mancini (2015) 


\section{Measuring trade in value added}

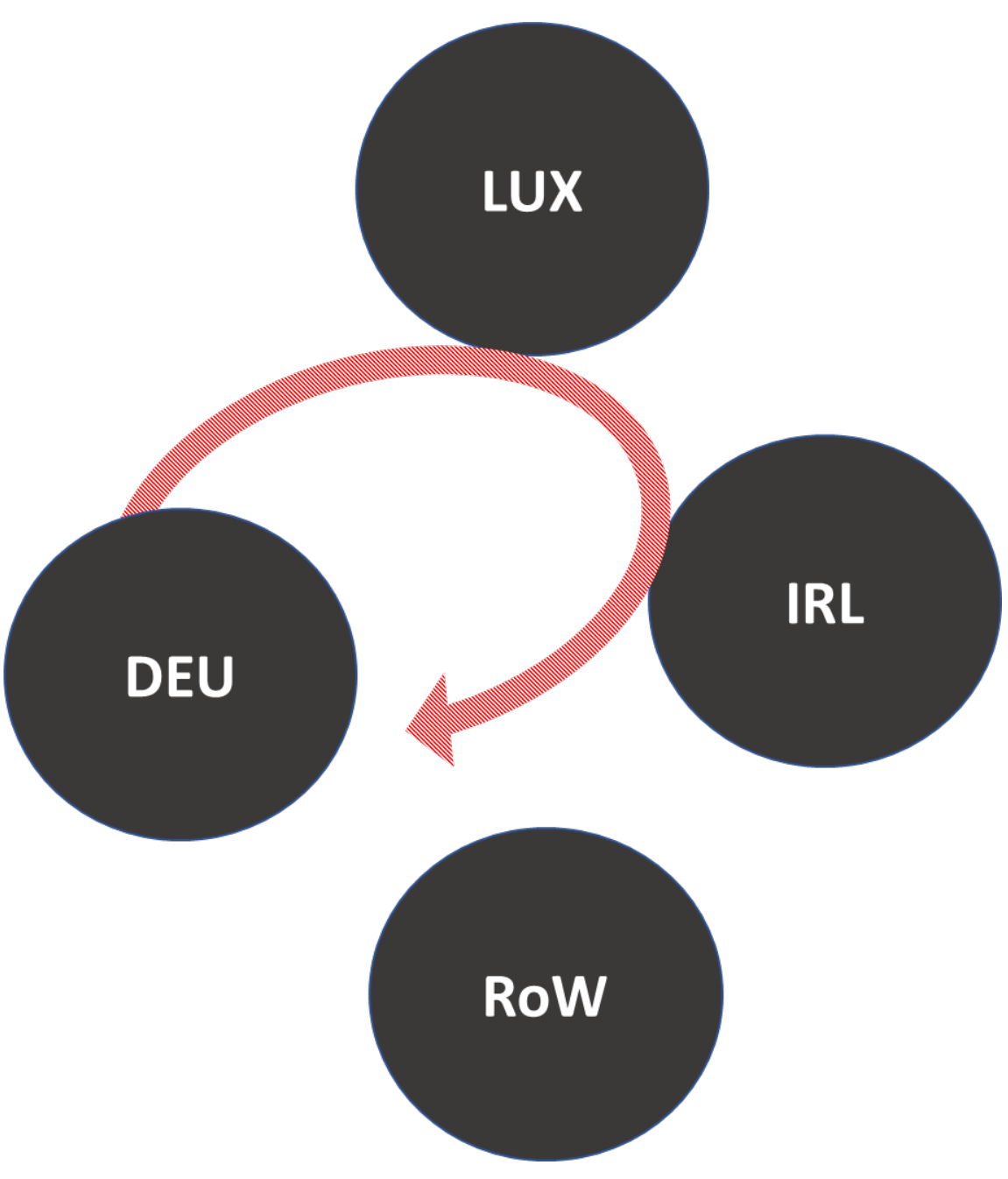

Domestic value added absorbed by the direct importer (DVA direct)

Domestic value added exported abroad which is reflected and absorbed at home (DVA reflected)

See Borin Mancini (2015) 


\section{Measuring trade in value added}

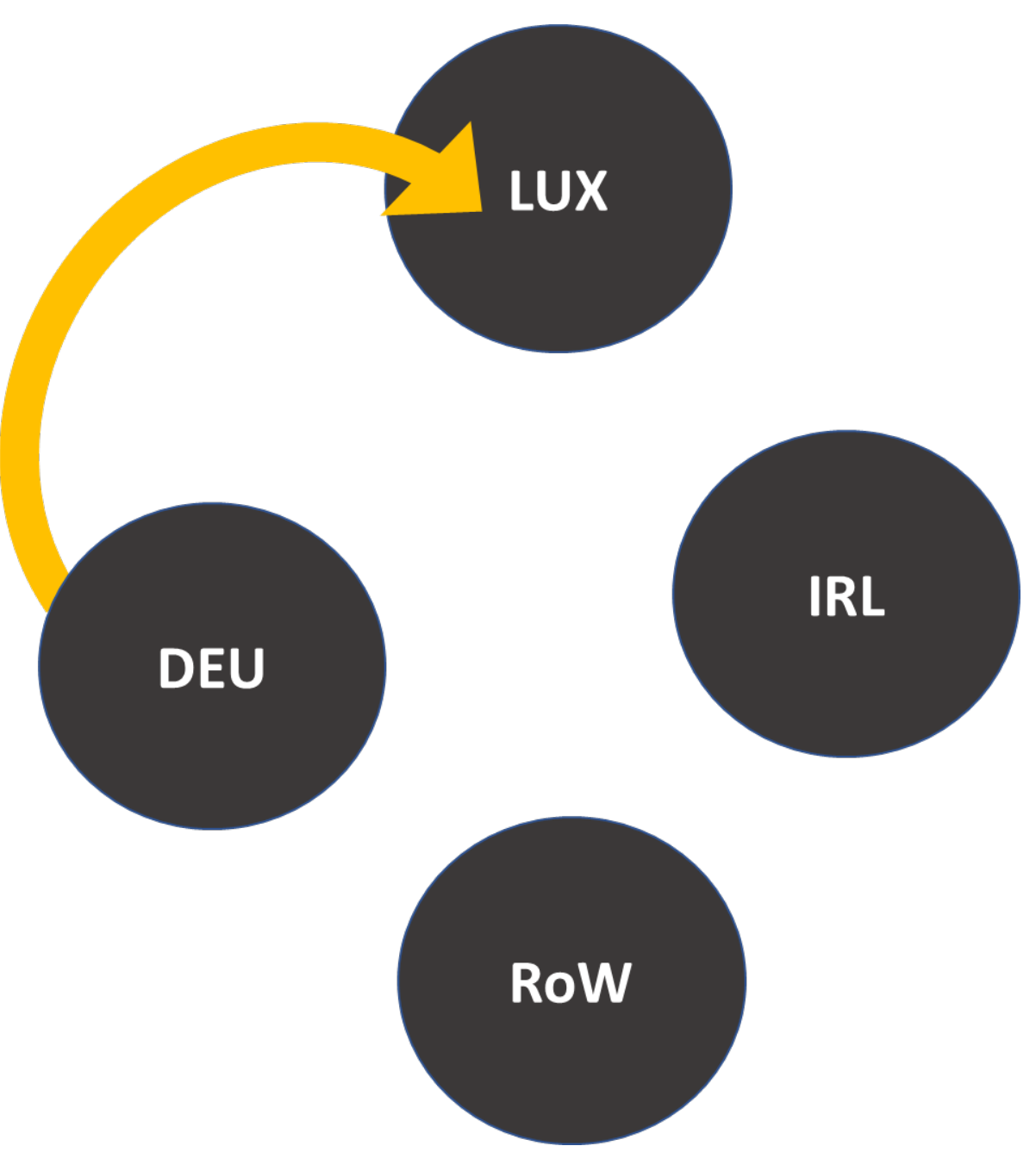

Domestic value added absorbed by the direct importer (DVA direct)

Domestic value added exported abroad which is reflected and absorbed at home (DVA reflected)

Domestic value added exported and further re-exported (as foreign value added in the GVC chain; DVA GVC)

See Borin Mancini (2015) 


\section{Measuring trade in value added}

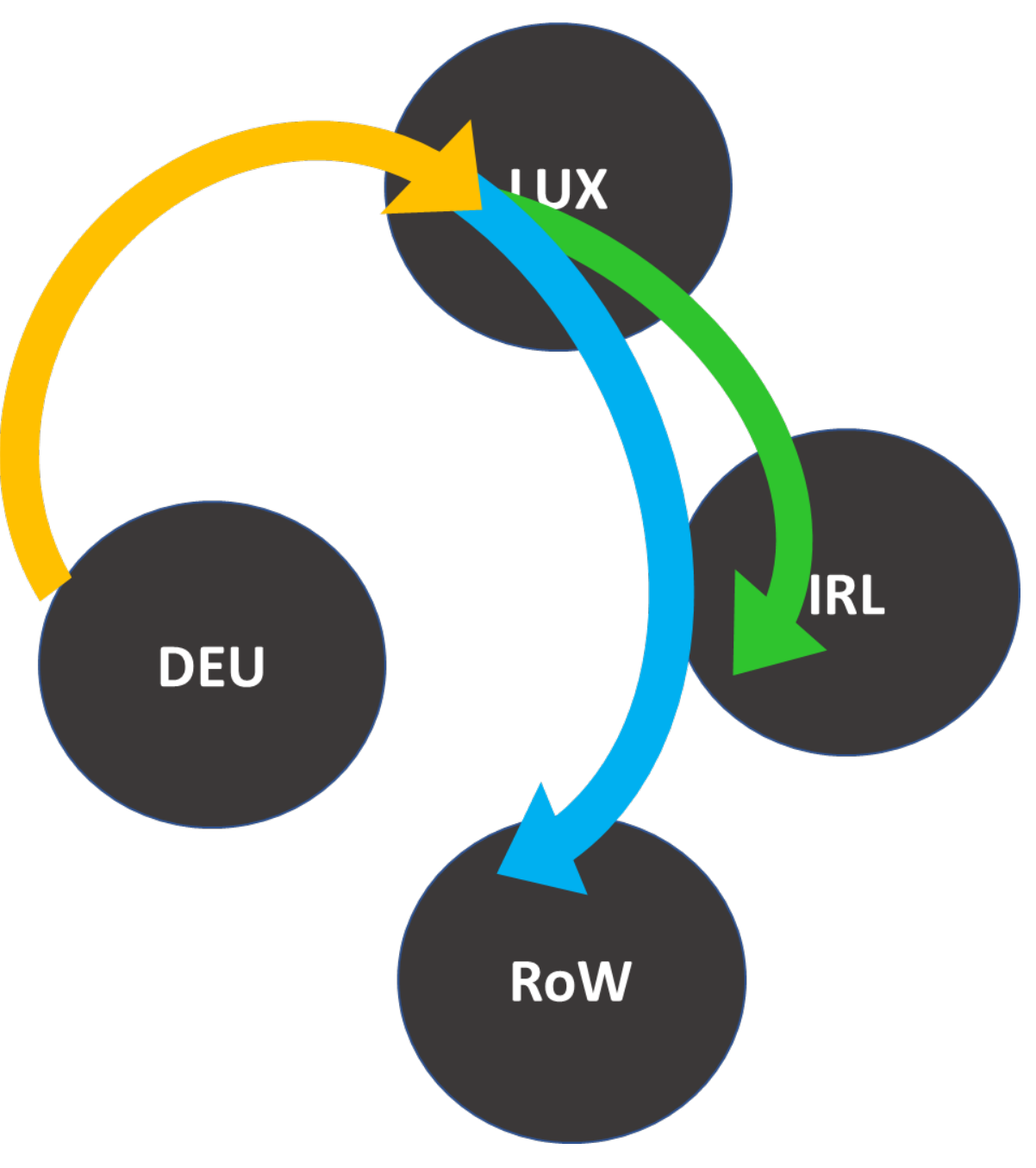

Domestic value added absorbed by the direct importer (DVA direct)

Domestic value added exported abroad which is reflected and absorbed at home (DVA reflected)

Domestic value added exported and further re-exported (as foreign value added in the GVC chain; DVA GVC)

Foreign value added exported directly to the final consumer country (FVA direct)

Foreign value added that is further exported by third countries in the GVC chain (FVA GVC)

See Borin Mancini (2015) 


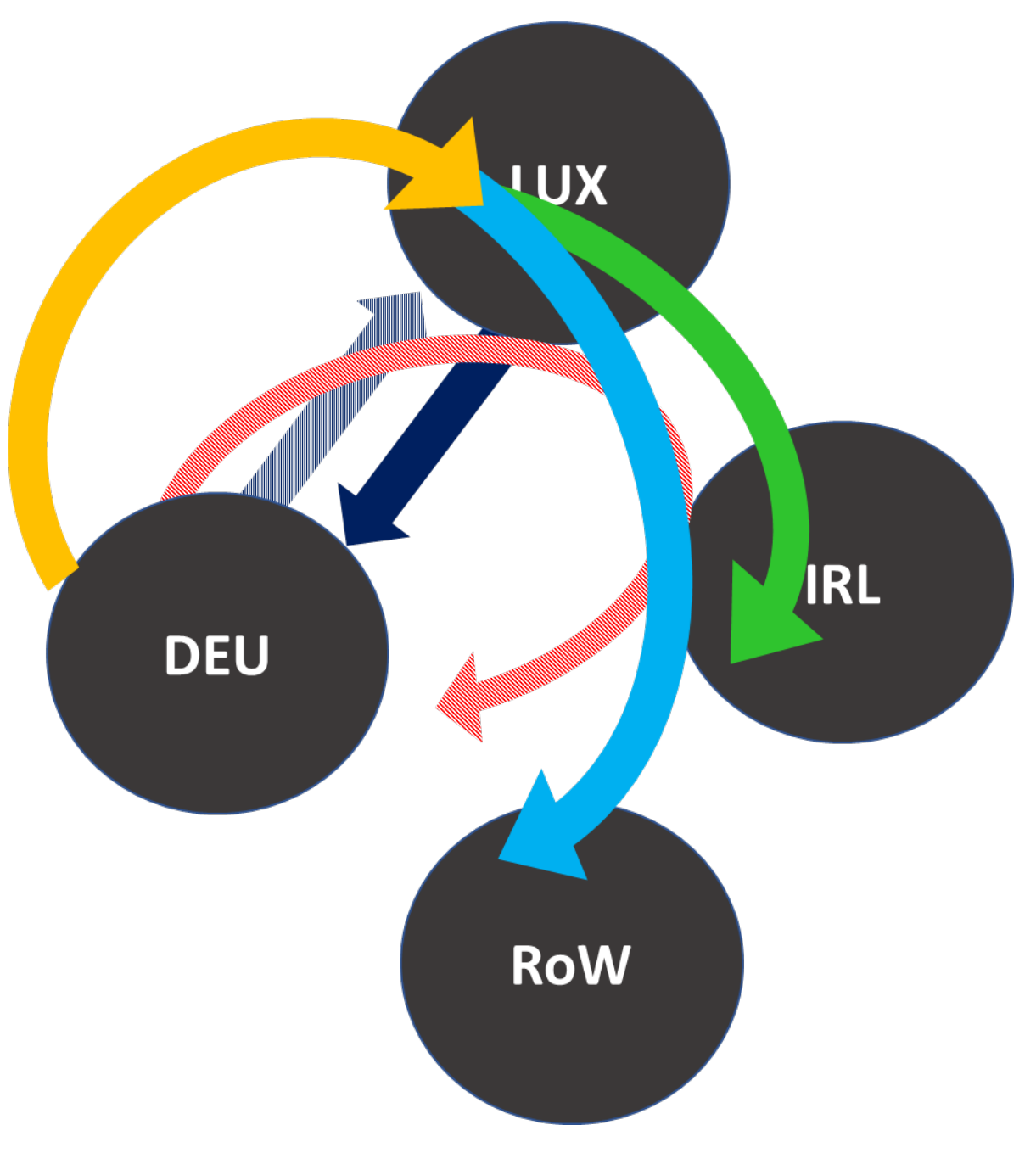

Domestic value added absorbed by the direct importer (DVA direct)

Domestic value added exported abroad which is reflected and absorbed at home (DVA reflected)

Domestic value added exported and further re-exported (as foreign value added in the GVC chain; DVA GVC)

Foreign value added exported directly to the final consumer country (FVA direct)

Foreign value added that is further exported by third countries in the GVC chain (FVA GVC)

See Borin Mancini (2015) 


\section{The VA representation of the Trade Balance in the Big 4 EA countries}
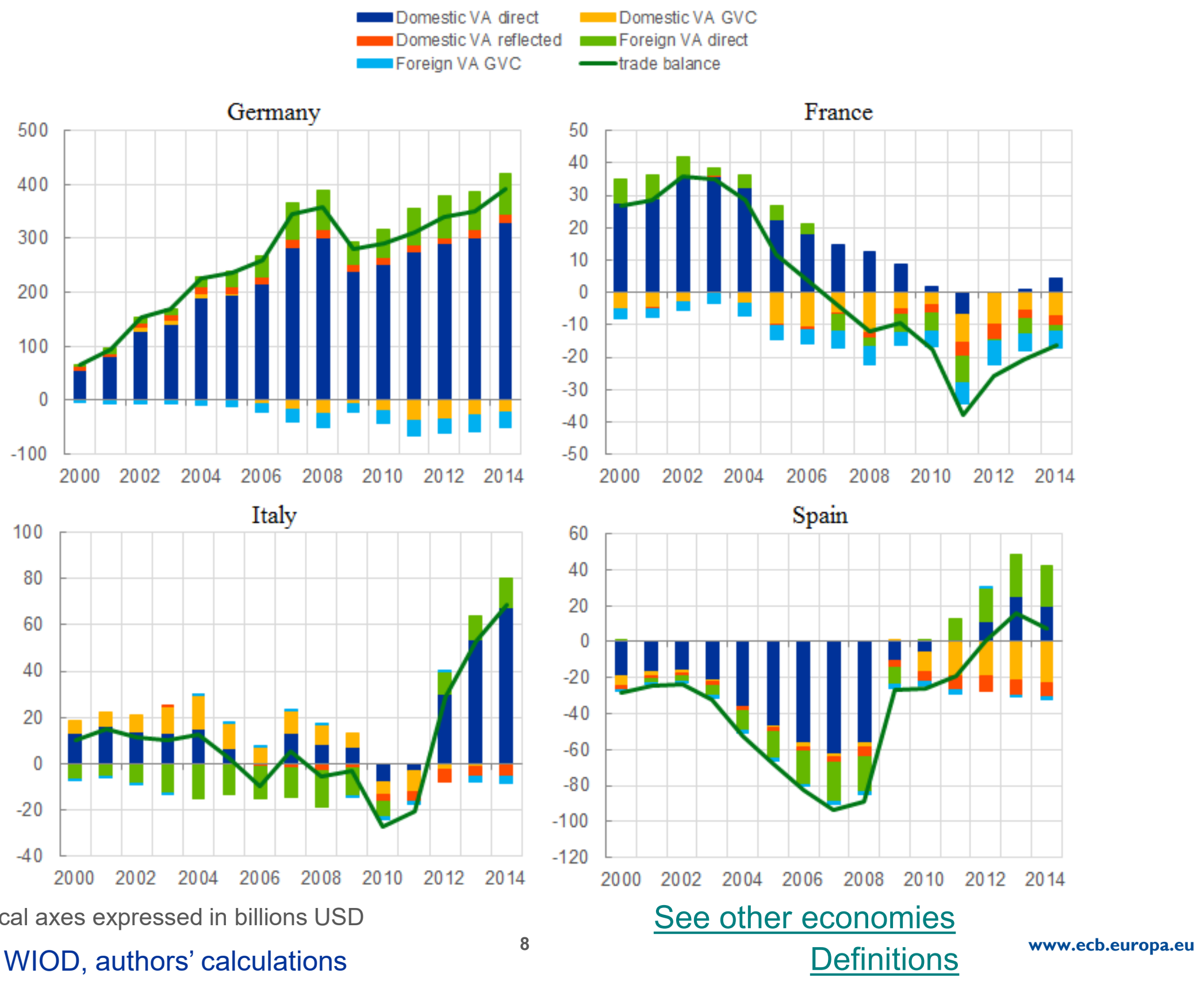

Sources: WIOD, authors' calculations Definitions 


\section{The VA representation of the Trade Balance in main EA Financial Centres}

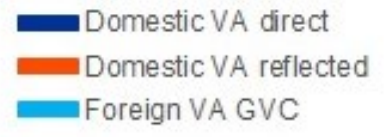

Domestic VA GVC

Foreign VA direct

Foreign VA GVC

_trade balance
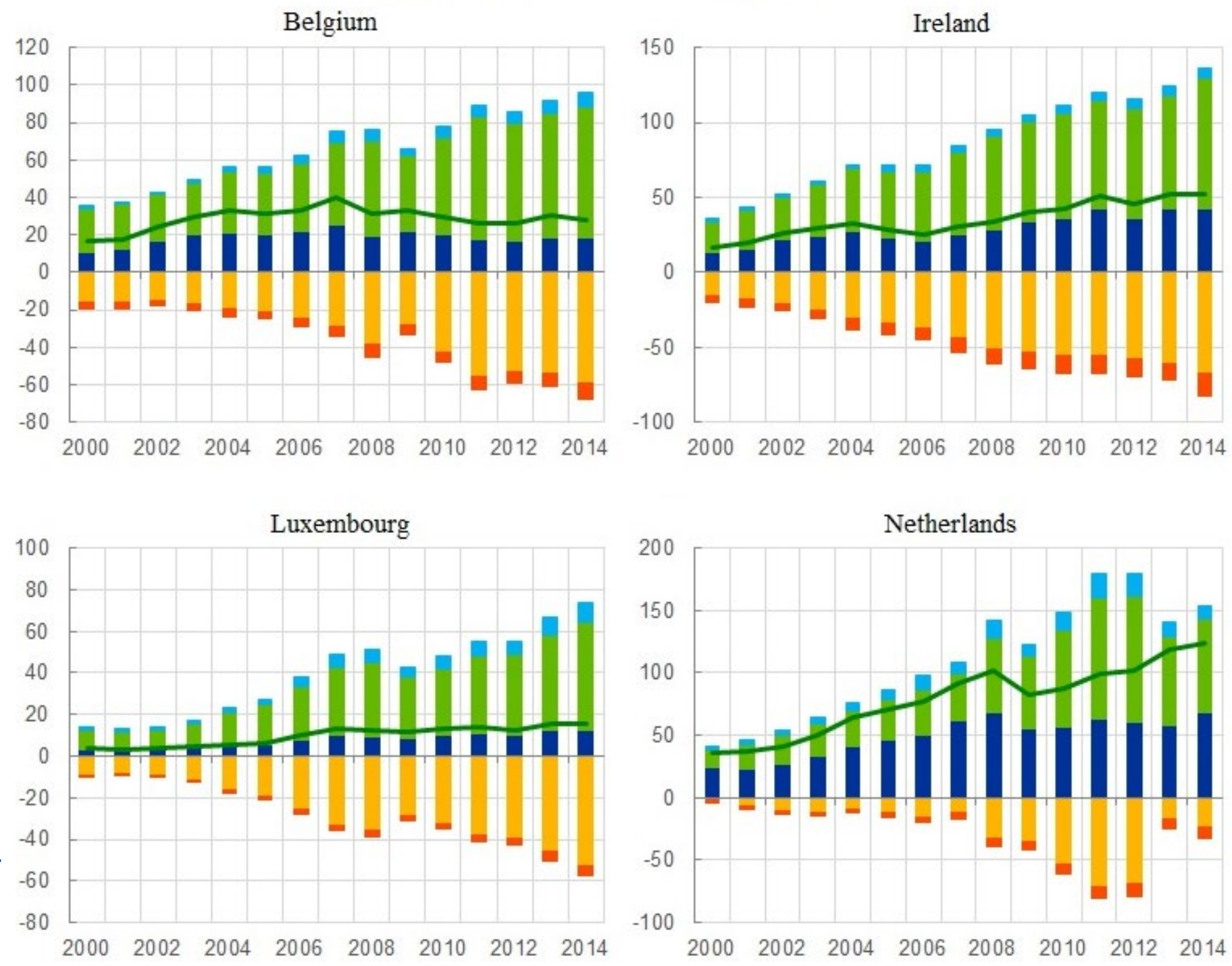

Note: vertical axes expressed in billions USD

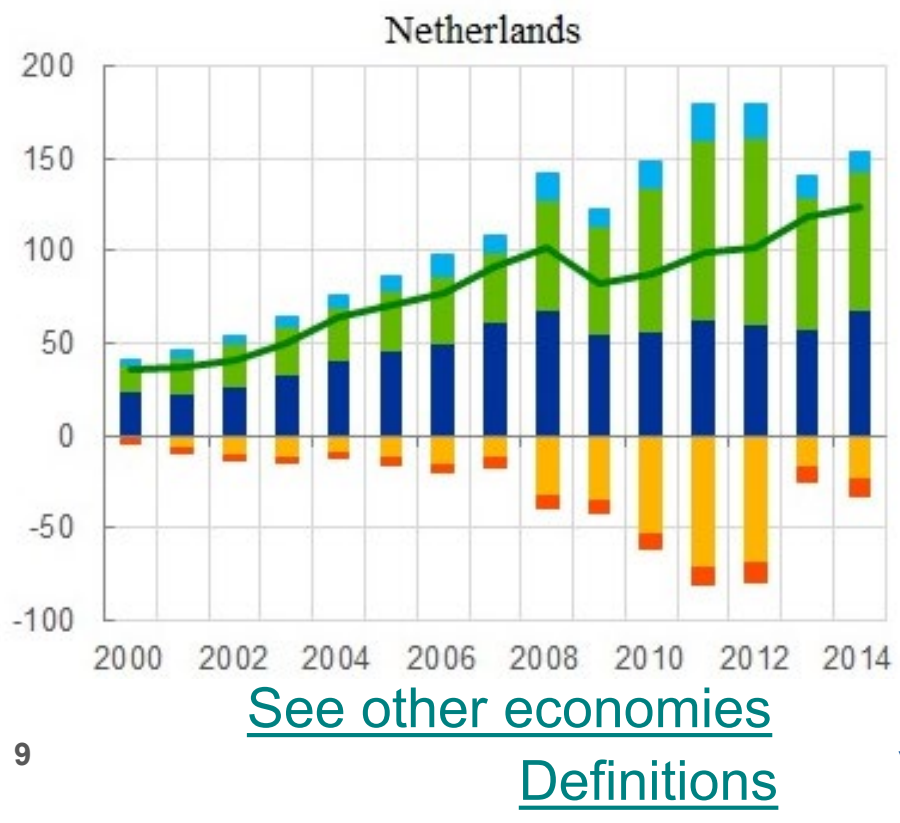

Sources: WIOD, authors' calculations

Definitions 


\section{Financial centres are the most downstream positioned in GVC}

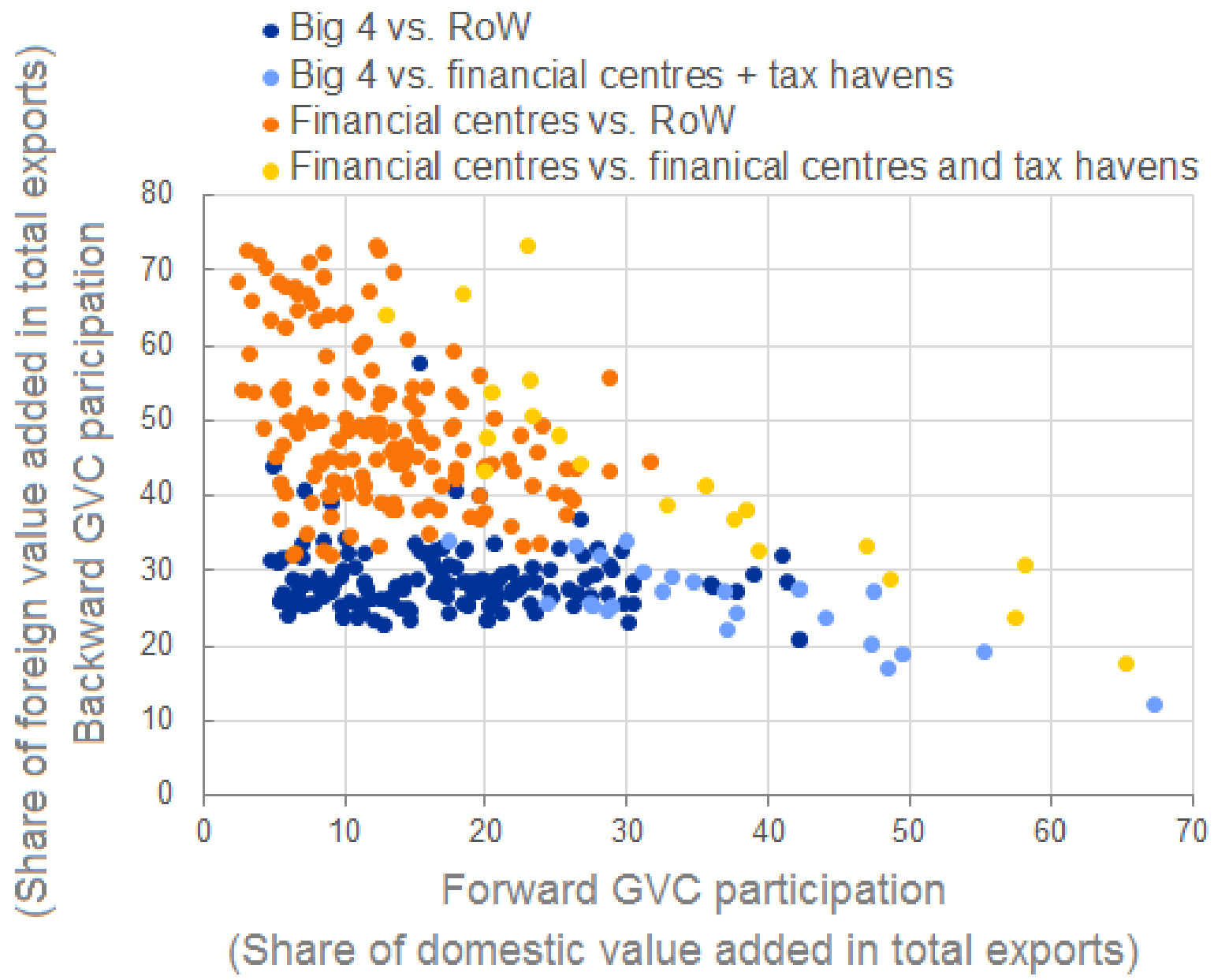

Note: Big 4 consists of Germany, Italy, France and Spain. Conduit refers to Belgium, Ireland, Luxembourg and the Netherlands. Tax havens are referring to Hungary, and Malta. Total exports have been netted out of double counting. 


\section{Improving current statistics of Trade in Value Added}

- Use an augmented gravity workhorse (Baldwin Taglioni (2011) Noguera (2012))

$>$ predict bilateral flows of gross and domestic value added exports

$>$ obtain FVA as a difference between the two predictions

$>$ re-compute mirror import statistics, TB \& GVC measures.

In the vein of Zucman, impose the same structure of exports and imports in VA across destination (TAX havens \& non). 


\section{Gravity specification}

$$
\begin{aligned}
& X_{i j t}=\exp \left[\alpha+\sum_{t r=1}^{8} \beta_{t r} \ln \left(\gamma_{j t}^{t r}\right)+\beta_{9} \ln \left(Y_{i t}\right)+\beta_{10} \ln \left(Y_{j t}\right)+\beta_{11} \ln \left(Y_{w t}\right)+\right. \\
& +\beta_{12} \ln \left(\text { Distance }_{i j}\right)+\beta_{13} \text { Language }_{i j}+\beta_{14} \text { Border }_{i j}+\sum_{T A=15}^{18} \beta_{r} I_{i j t}+ \\
& \left.+\beta_{19} \ln M R T_{i t}^{\text {out }}+\beta_{20} \ln M R T_{j t}^{i n}\right] \eta_{i j t}
\end{aligned}
$$

$>$ Controls for GVC structure: $\gamma_{j t}^{t r}$

$>$ Controls for countries' size: $Y_{i t}, Y_{j t}, Y_{w t}$,

$>$ Controls for bilateral trade barriers: Distance ${ }_{\mathrm{ij}}$, Language $_{\mathrm{ij}}$, Border $_{\mathrm{ij}}$,

$>$ Controls for trade and economic integration: $\mathrm{I}_{\mathrm{ijt}}(\mathrm{CU}, \mathrm{CM}, \mathrm{EU}, \mathrm{FTA})$

$>$ Controls for multilateral trade resistance: $\mathrm{MRT}_{\mathrm{it}}^{\text {out }}, \mathrm{MRT}_{\mathrm{jt}}^{\mathrm{in}}$ (two step procedure, see Anderson van Wincoop (2003) and IMF WEO (2019). 


\section{Standard gravity controls}

\begin{tabular}{|c|c|c|c|}
\hline VARIABLES & $\begin{array}{l}\text { (1) } \\
\text { EXP }\end{array}$ & $\begin{array}{c}\text { (2) } \\
\text { DVA DIR } \\
\end{array}$ & $\begin{array}{c}\text { (3) } \\
\text { DVA GVC }\end{array}$ \\
\hline $\ln \left(Y_{\text {it }}\right)$ & $0.752^{* * * *}$ & $0.823^{*} * * *$ & $0.731^{*} * * *$ \\
\hline $\ln \left(Y_{j t}\right)$ & $0.882^{* * * *}$ & $0.916 * * *$ & $0.736^{* * * *}$ \\
\hline $\ln \left(Y_{w t}\right)$ & $-0.698 * * * *$ & $-0.816 * * * *$ & $-0.848^{* * * *}$ \\
\hline $\ln \left(\right.$ Distance $\left._{i j}\right)$ & $-0.679 * * * *$ & $-0.637 * * * *$ & $-0.703 * * *$ \\
\hline Language $_{i j}$ & $0.0734 * *$ & -0.000740 & $0.218 * * * *$ \\
\hline Border $_{i j}$ & $0.513 * * *$ & $0.536^{* * * *}$ & $0.301 * * * *$ \\
\hline $\mathrm{FTA}_{\mathrm{ijt}}$ & $0.165^{* * * *} *$ & $0.146^{* * *}$ & $0.102^{* * *}$ \\
\hline $\mathrm{CU}_{\mathrm{ijt}}$ & 0.0986 & $0.177 * *$ & -0.0613 \\
\hline $\mathrm{CM}_{\mathrm{ijt}}$ & $0.150 * * *$ & $0.198 * * * *$ & $0.191 * * * *$ \\
\hline $\mathrm{EU}_{\mathrm{ijt}}$ & $0.0938 *$ & $0.128 * *$ & 0.0607 \\
\hline $\ln \left(\mathrm{MRT}_{\mathrm{it}}^{\text {out }}\right)$ & $0.948 * * *$ & $0.893 * * *$ & $1.672 * * * *$ \\
\hline $\ln \left(\mathrm{MRT}_{\mathrm{jt}}^{\mathrm{in}}\right)$ & $2.539 * * *$ & $1.929 * * * *$ & $1.263^{* * * *}$ \\
\hline Observations & 24,600 & 24,600 & 24,600 \\
\hline R-squared & 0.804 & 0.818 & 0.742 \\
\hline
\end{tabular}

Robust standard errors in parentheses

$* * * \mathrm{p}<0.01, * * \mathrm{p}<0.05, * \mathrm{p}<0.1$ 


\section{New gravity controls}

8 extra terms representing the aggregate trade structure in value added of the bilateral importer $(\mathrm{j})$ with the rest of the world (excluding $\mathrm{i}$ )

\begin{tabular}{|c|c|c|c|}
\hline VARIABLES & $\begin{array}{c}(1) \\
\text { EXP }\end{array}$ & $\begin{array}{c}\text { (2) } \\
\text { DVA DIR } \\
\end{array}$ & $\begin{array}{c}\text { (3) } \\
\text { DVA GVC }\end{array}$ \\
\hline $\ln \left(\mathrm{IMP}-\mathrm{DVA}-\mathrm{DIR} \mathrm{jt}_{\mathrm{jt}}\right)$ & -0.201 & -0.133 & $-1.516 * * *$ \\
\hline $\ln \left(\mathrm{IMP}-\mathrm{DVA}-\mathrm{GVC}_{\mathrm{jt}}\right)$ & $-0.302 * * *$ & $-0.454 * * *$ & $-0.367 * * *$ \\
\hline $\ln \left(\right.$ EXP-DVA-DIR $\left.{ }_{j t}\right)$ & $-0.804 * * * *$ & $-0.756^{* * * *}$ & $-1.029 * * * *$ \\
\hline $\ln \left(\right.$ EXP-DVA-GVC $\left.{ }_{j \mathrm{t}}\right)$ & $0.509 * * *$ & $0.512^{* * * *}$ & $0.857 * * *$ \\
\hline ln(IMP-FVA-DIR ${ }_{\mathrm{jt}}$ ) & 0.0667 & 0.196 & $0.810 * * *$ \\
\hline $\ln \left(\mathrm{IMP}-F V A-\mathrm{GVC}_{\mathrm{jt}}\right.$ ) & -0.00621 & -0.0757 & $-0.542^{* * * *}$ \\
\hline $\ln \left(\mathrm{EXP}-\mathrm{FVA}-\mathrm{GVC}_{\mathrm{jt}}\right)$ & $0.997 * * * *$ & $0.971 * * *$ & $2.296^{* * * *}$ \\
\hline $\ln \left(\right.$ EXP-FVA-GVC $\left.{ }_{j t}\right)$ & $-0.327 * * * *$ & $-0.349 * * *$ & $-0.405 * * *$ \\
\hline Observations & 24,600 & 24,600 & 24,600 \\
\hline R-squared & 0.804 & 0.818 & 0.742 \\
\hline
\end{tabular}

Robust standard errors in parentheses

*** $\mathrm{p}<0.01, * * \mathrm{p}<0.05, * \mathrm{p}<0.1$ 


\section{Robustness checks}

$>$ Gravity estimation on the corrected dataset (predicted exports replace reported values for financial centres): smaller elasticity of exports to the importer GVC trade terms (FVA-DIR DVA-GVC)

$>$ Gravity OLS estimation: countries demand shifters less important, FTA insignificant, the negative effect of distance on trade is larger

$>$ Gravity including country fixed effects: as MRT terms drop out of the specification, the bilateral importer trade structure becomes more relevant in determining exports from $\mathrm{i}$ to $\mathrm{j}$, Domestic demand less important, foreign demand more important, economic integration matters more (probably better identified DD effects when country's fixed effects are included).

$>$ Gravity with lower and higher $\sigma$ (elasticity of substitution across varieties): MRT terms gains relevance as $\sigma$ increases. 


\section{The adjusted trade balance of financial centres}
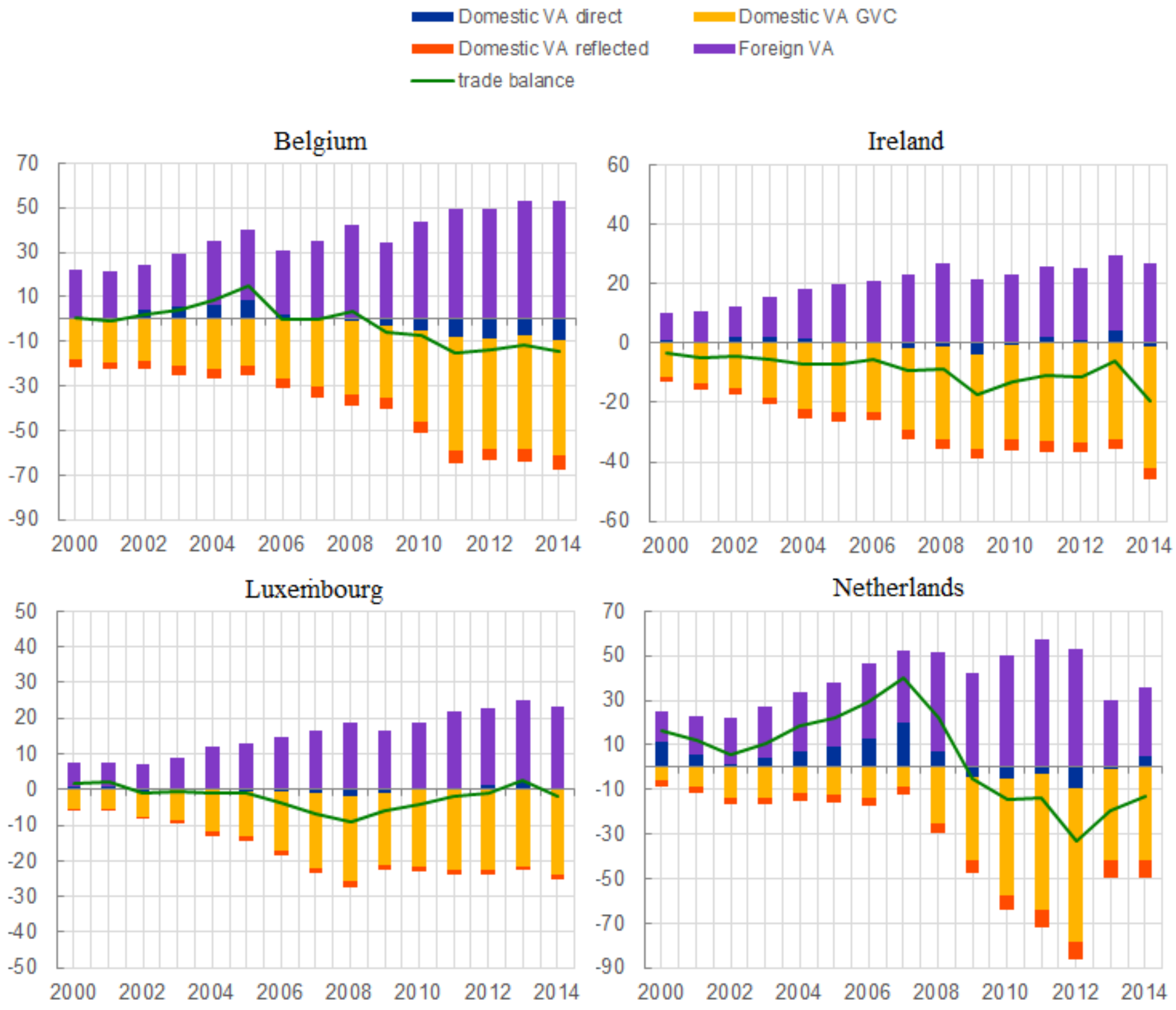

Sources: WIOD, authors' calculations 


\section{Revised positioning and participation}

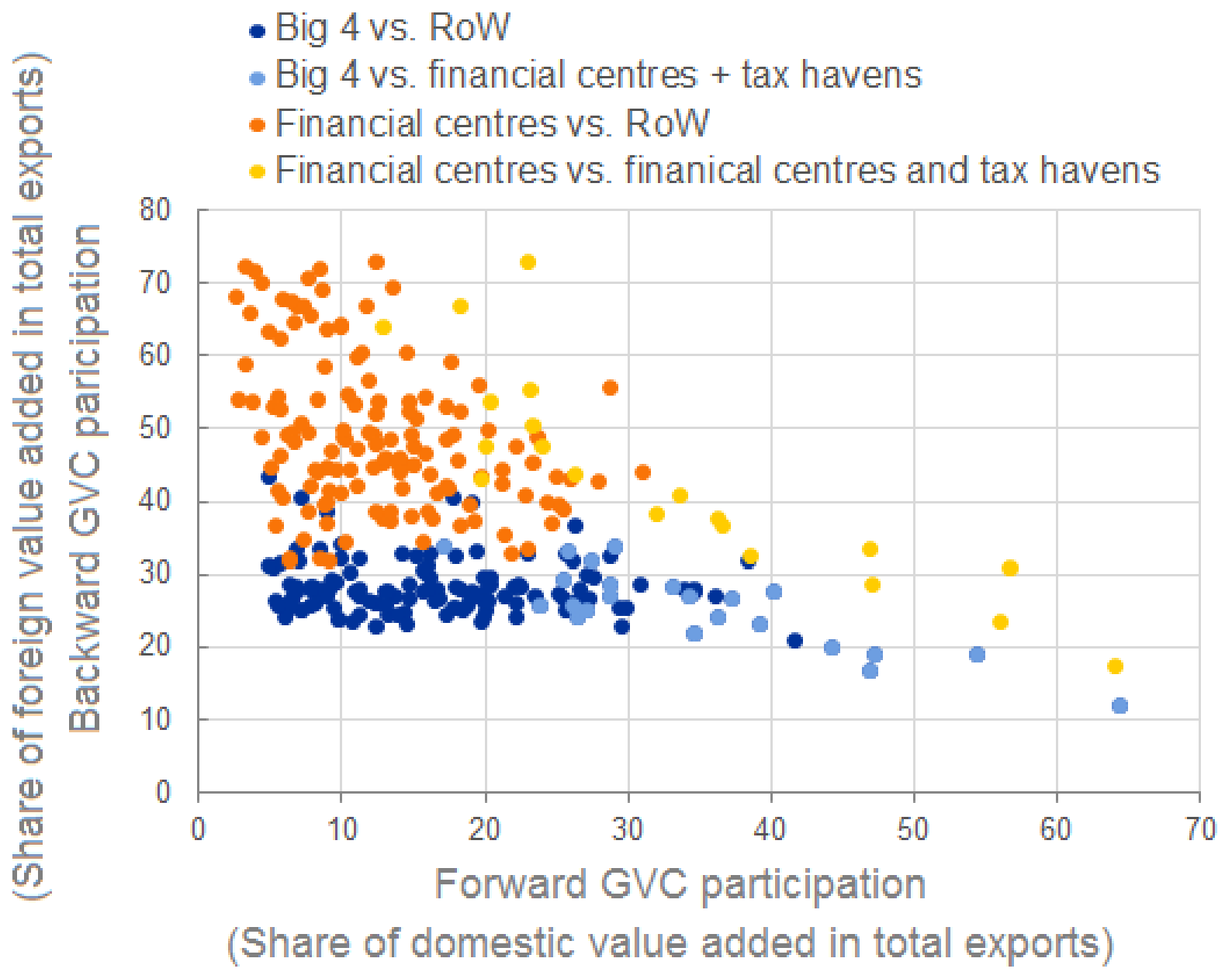

Note: Big 4 consists of Germany, Italy, France and Spain. Conduit refers to Belgium, Ireland, Luxembourg and the Netherlands. Tax havens are referring to Hungary, and Malta. Total exports have been netted out of double counting. 


\section{MAIN TAKEAWAYS}

The trade balance decomposition by value added content reveals:

1. for the main euro area financial centres

- large deficits in domestic value added exported and further reexported,

- $\quad$ large surpluses in foreign value added exported directly to the final consumers,

2. for other main euro area economies

- large surpluses in domestic value added absorbed by the direct importer.

3. Financial centres are the most downstream positioned in GVC owing to services in intangibles only entering the very last stage of production.

4. Trade surpluses in main euro area financial centres disappears in gravity predictions.

5. Profits shifted to these economies are estimated to be around USD 300 billion. 


\section{THANKS FOR THE ATTENTION}




\section{Reserve slides}




\section{TP\&PS on WIOD through BOP}

"Transfer pricing and relocation of IP washes out in the current account. Exports are under reported by the same amount as overseas investment income is over reported." Avdjeiev, Everett, Lane \& Shin, 2018, "Tracking the international footprints of global firms" BIS quarterly review

TP generates large discrepancies in mirror trade statistics. Within the EU the gap between service exports and imports is 11 p.p. of total service exports (8 p.p accounted by financial centres).

Torlsov, Wier, Zucman (2019) "The missing profits of Nations"

The World Input Output Database (WIOD) is as afflicted by Profit shifting and the practice of transfer pricing as BOP (primary data source) in two ways :

1. Misreporting of intra-firm trade values;

2. The implicit pricing of the use of intangibles (brand names, trademarks, software and other knowledge systems). It shows up as a difference between the final purchasers' and ex-factory prices of the product.

Timmer et al. (2015) "An illustrated user guide to WIOD". 


\section{BOP items afflicted by TP\&PS}

\section{Current account balance}

( $\%$ of gross national income)

United States

United Kingdom

France

Spain

Italy

EU22

Belgium

Germany

Netherlands

Malta

Puerto Rico

Ireland

Luxembourg

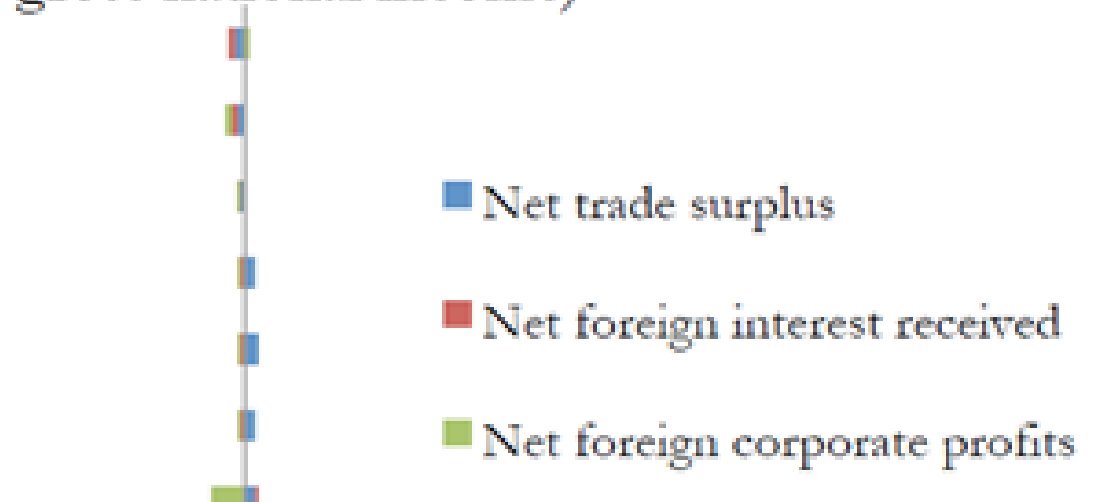

Source: "Why High-Tax Countries Let Tax Havens Flourish". (Nov 2017). Authors: Torslov, T., Wier, L., Zucman, G. 


\section{Trade balances corrected for profit shifting}

Euro area trade balance

\& profit shifting

(\% of GDP)
Trade balances \& profit shifting effects

(\% of GDP)
- Official trade balance

- Corrected trade balance
- Official trade balance (\% of GDP)

- Corrected trade balance ( $\%$ of GDP)

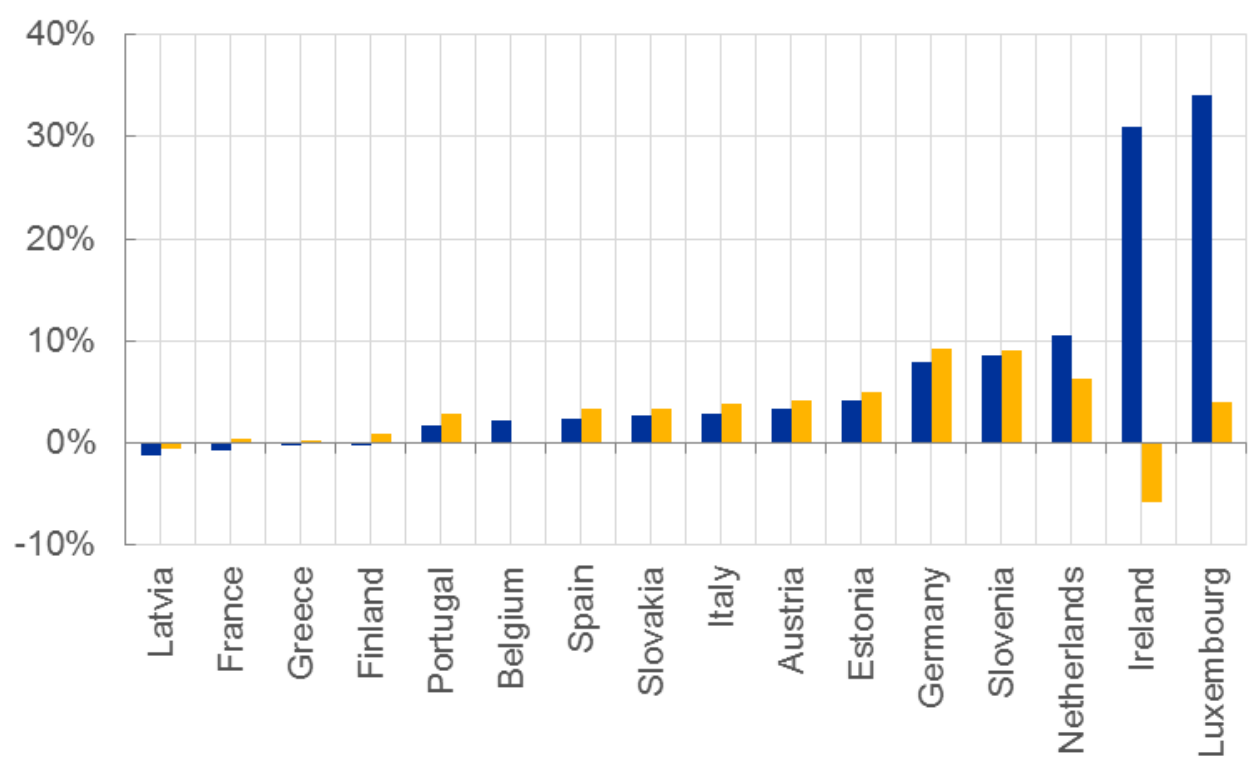

Note: Cyprus, Malta and Lithuania are excluded.

$\underline{\text { Income balance }}$

Sources: "The Missing Profits of Nations". (Sep 2019). Authors: Torslov, T., Wier, L., Zucman, G. and the authors' calculations 


\section{Income balances corrected for profit shifting}

Aggregated income balance corrected for profit shifting, Euro Area

(\% of GDP)

- Official income balance $\square$ Corrected income balance

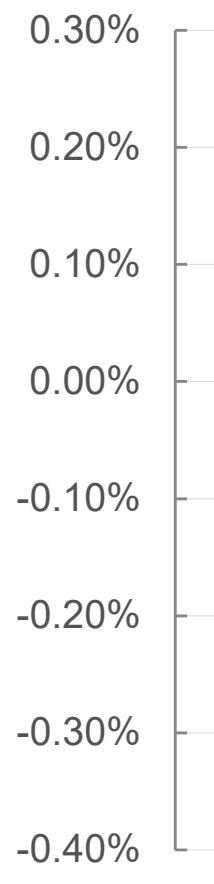

Income balances corrected for profit shifting

(\% of GDP)

- Official income balance $\quad$ Corrected income balance

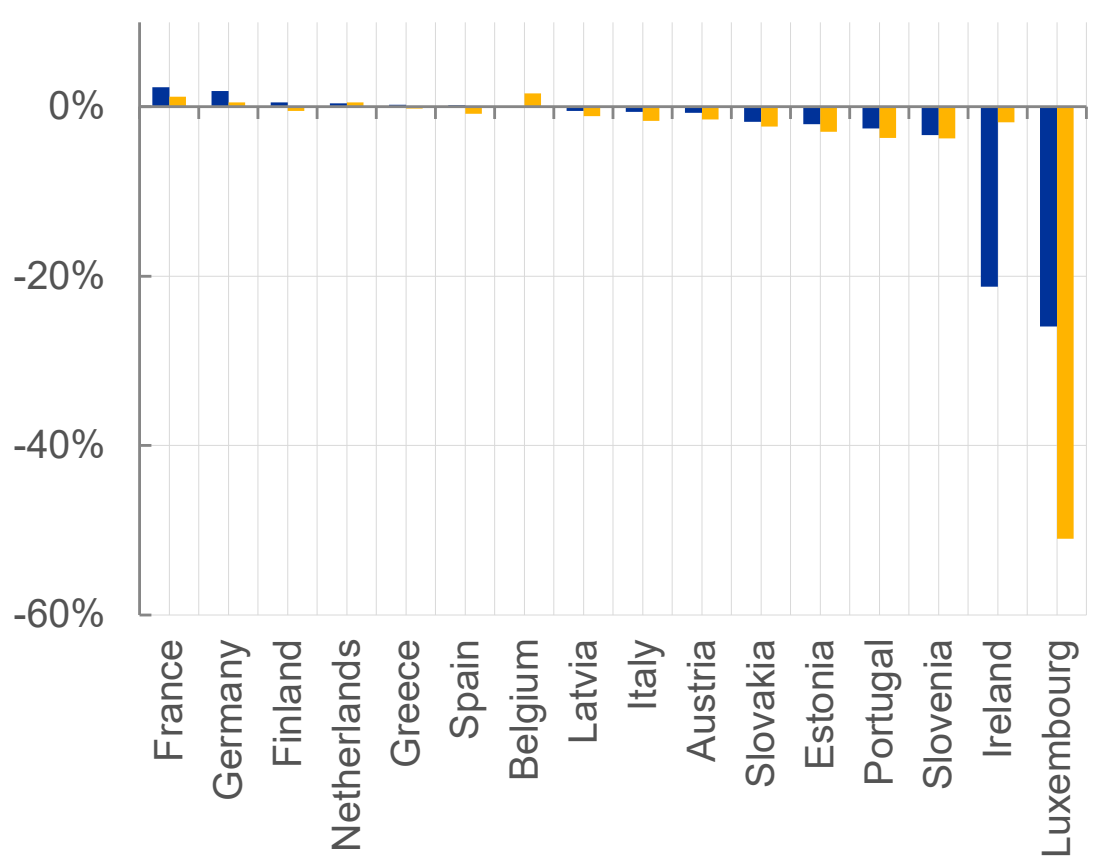

Note: Cyprus, Malta and Lithuania are excluded.

$\underline{\text { back }}$

Sources: "The Missing Profits of Nations". (Sep 2019). Authors: Torslov, T., Wier, L., Zucman, G. and the authors' calculations 


\section{The current state of art: GVC position}

GVC position=log(1+DVAinEXPij/TotEXPij) - log (1+FVAinEXPij/TotEXPij)

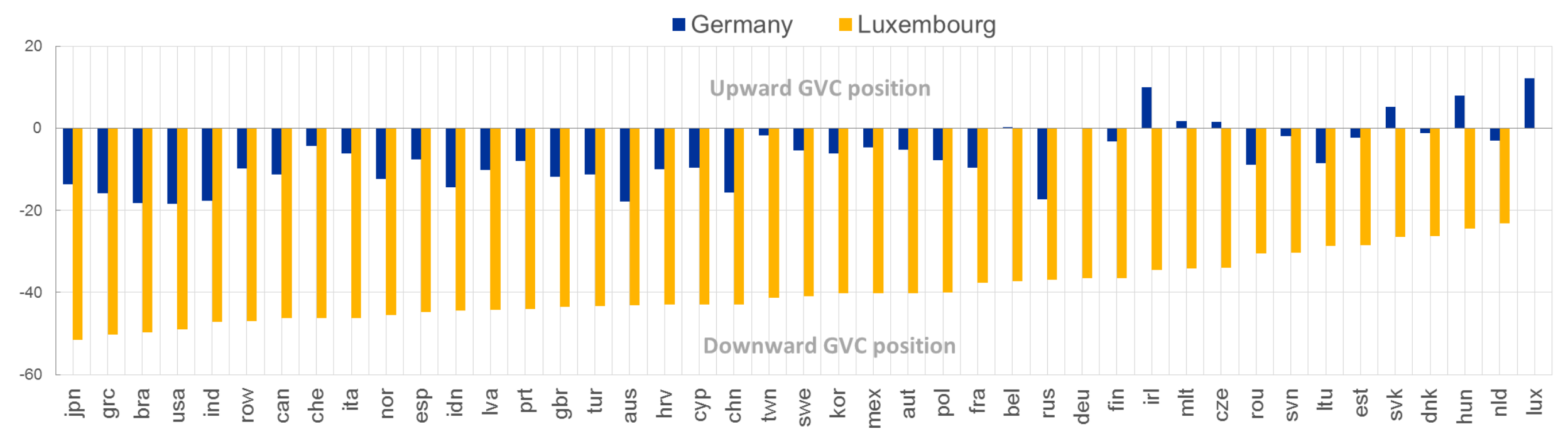




\section{Follow the Value Added flows in GVCs: measurement issues and solutions}

- From aggregate to bilateral (and sectoral) decomposition of trade flows. Why a bilateral decomposition?

- country A decomposition, term 9, as $\operatorname{VBBBAAAB(I-ABB)-1EB}$.

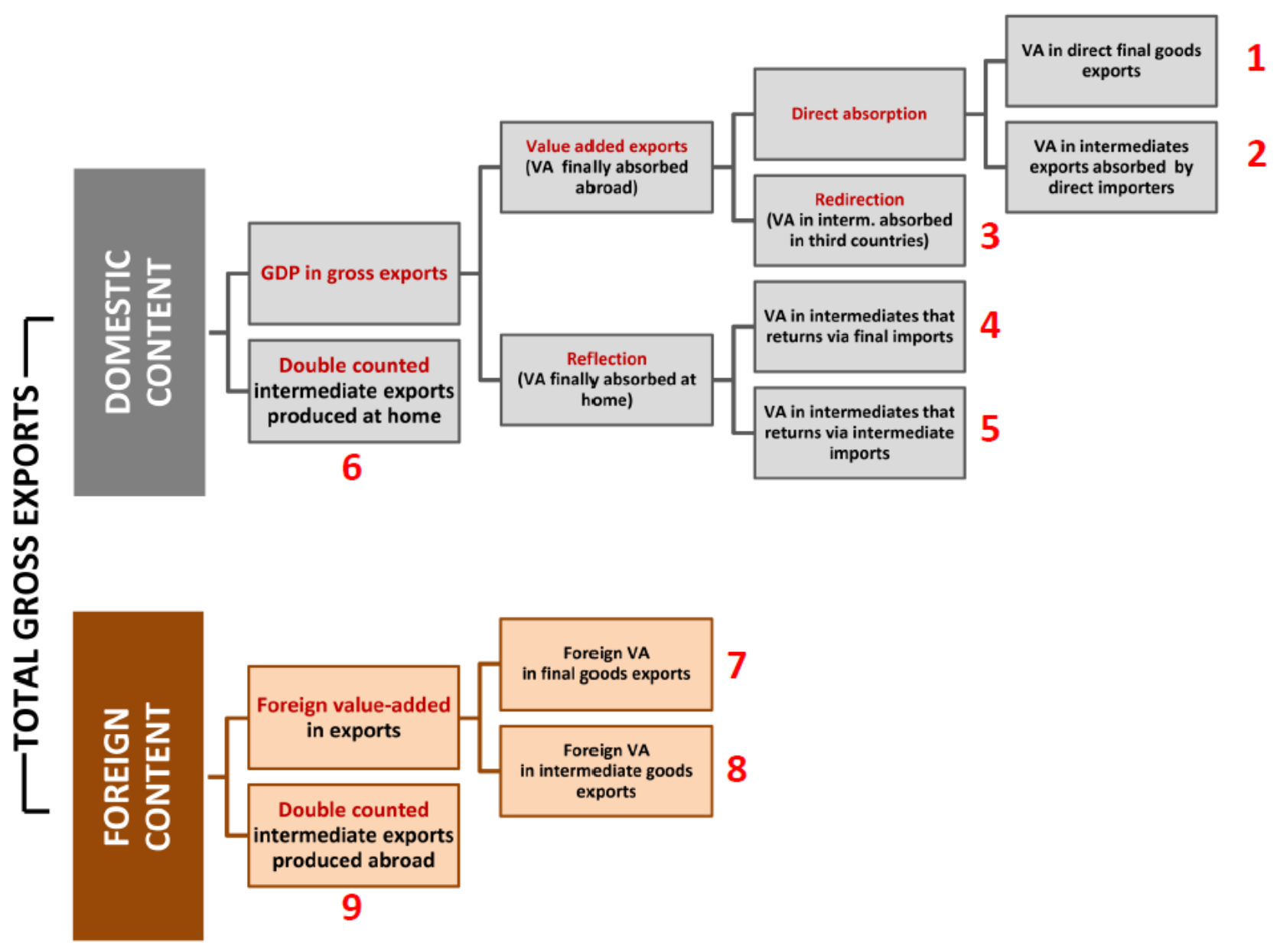




\section{Bilateral decomposition of Borin Mancini (2015)}

1 domestic value added (VA) in direct final good exports;

2a domestic VA in intermediate exports absorbed by direct importers as local final goods;

2b domestic VA in intermediate exports absorbed by direct importers as local final goods only after additional processing stages abroad;

$2 \mathrm{c}$ domestic VA in intermediate exports absorbed by third countries as local final goods;

3a domestic VA in intermediate exports absorbed by third countries as final goods from direct bilateral importers;

3b domestic VA in intermediate exports absorbed by third countries as final goods from direct bilateral importers only after further processing stages abroad;

$3 c$ domestic VA in intermediate exports absorbed by direct importers as final goods from third countries;

3d domestic VA in intermediate exports absorbed by third countries as final goods from other third countries;

4a domestic VA in intermediate exports absorbed at home as final goods of the bilateral importers;

4b domestic VA in intermediate exports absorbed at home as final goods of the bilateral importers after additional processing stages abroad;

$4 \mathrm{c}$ domestic VA in intermediate exports absorbed at home as final goods of a third country;

5 domestic VA in intermediate exports absorbed at home as domestic final goods;

6 double-counted intermediate exports originally produced at home;

7 foreign VA in exports of final goods;

8 foreign VA in exports of intermediate goods directly absorbed by the importing country $r$;

$9 \mathrm{a}$ and $9 \mathrm{~b}$ foreign VA in exports of intermediate goods re-exported by $r$ directly to the country of final absorption.

$9 c$ and 9d double-counted intermediate exports originally produced abroad. 


\section{Luxembourg vis à vis the world}

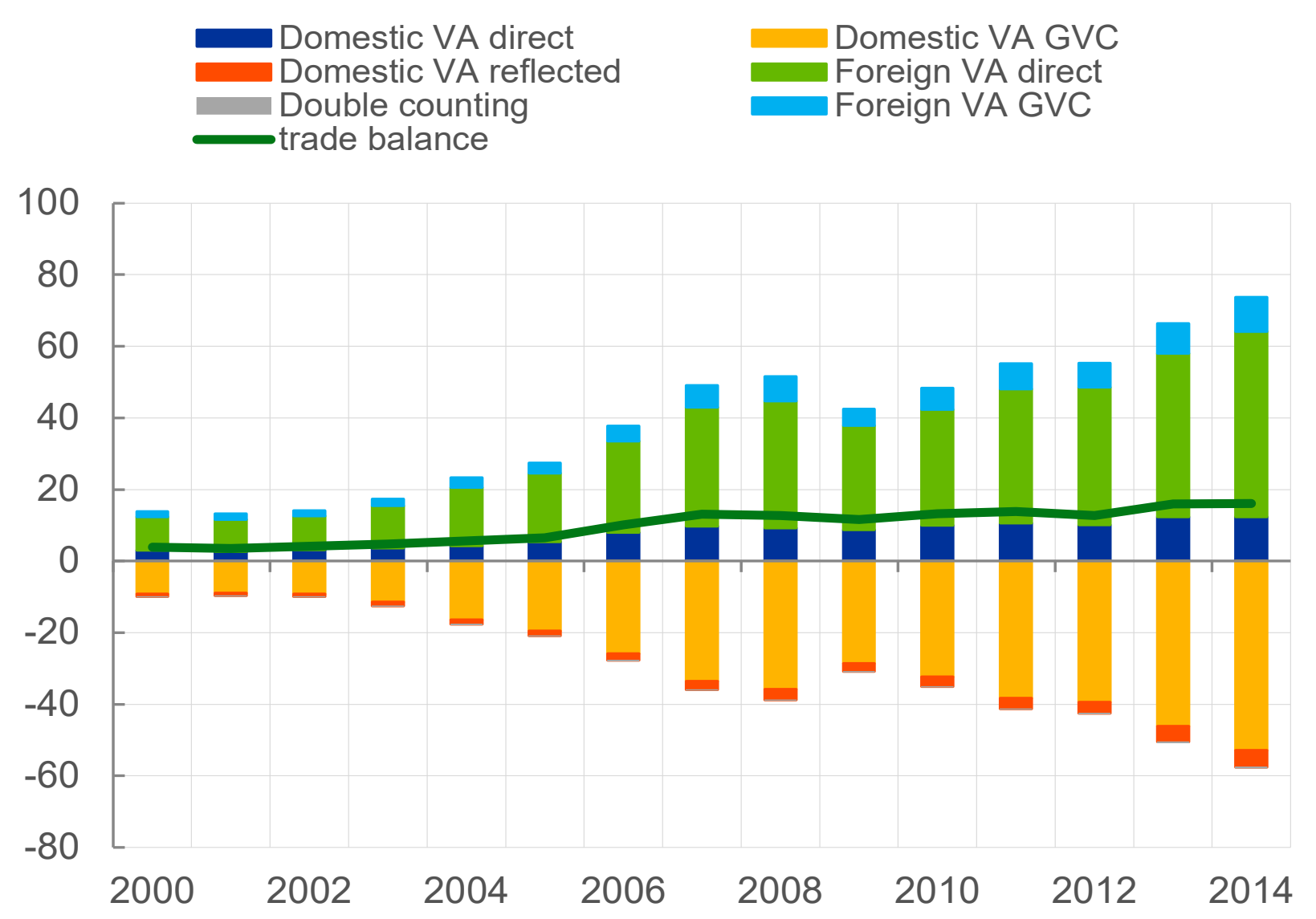

Note: vertical axes expressed in billions USD

Sources: WIOD, authors' calculations 


\section{Bilateral TBVA of Luxembourg... where does FVA end-up?}

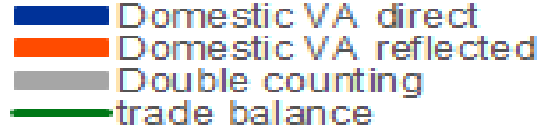

Luxembourg vs. Germany

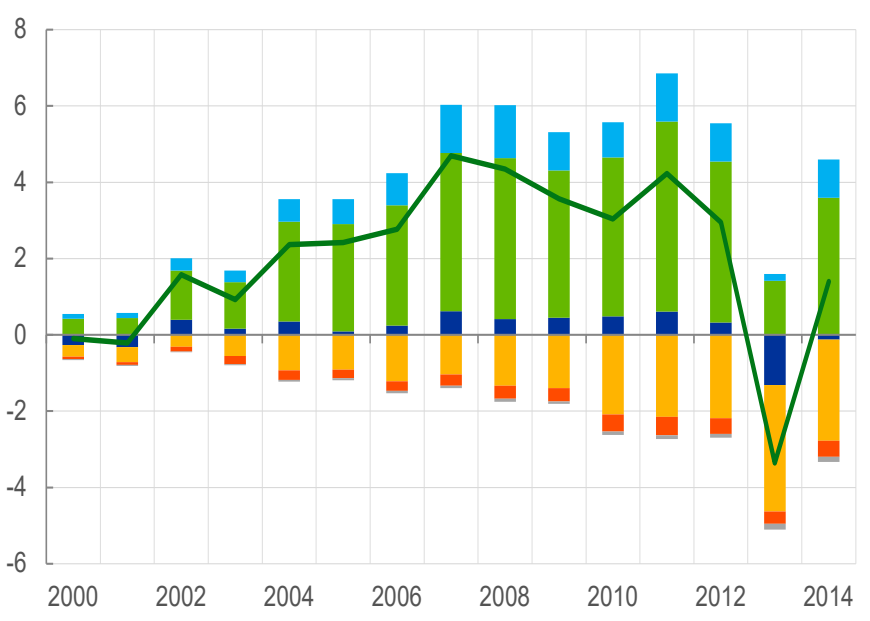

Luxembourg vs. France

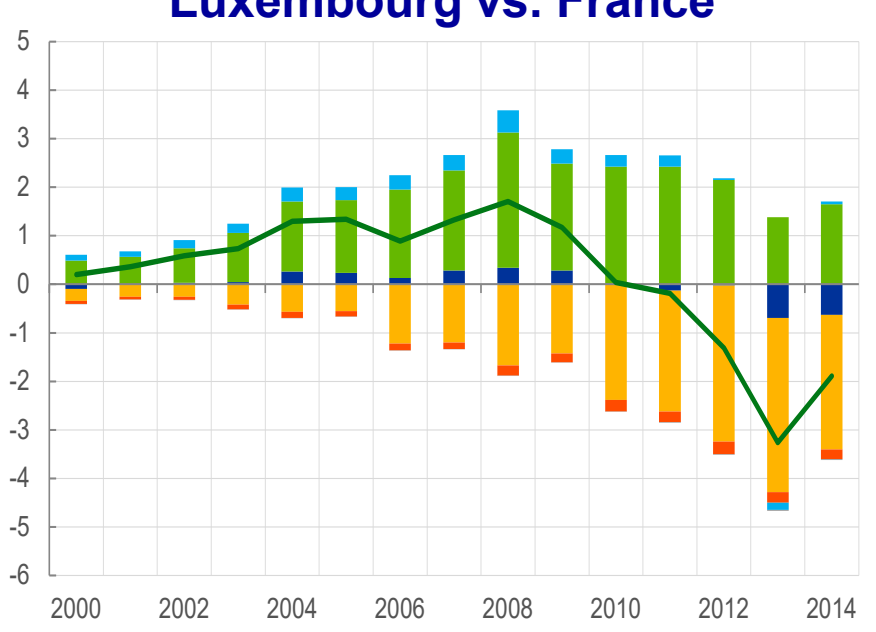

Note: vertical axes expressed in billions USD

Sources: WIOD, authors' calculations
Domestic VA GVC
Foreign VA direct

Foreign VA direct
Foreign VA GVC

Luxembourg vs. Ireland

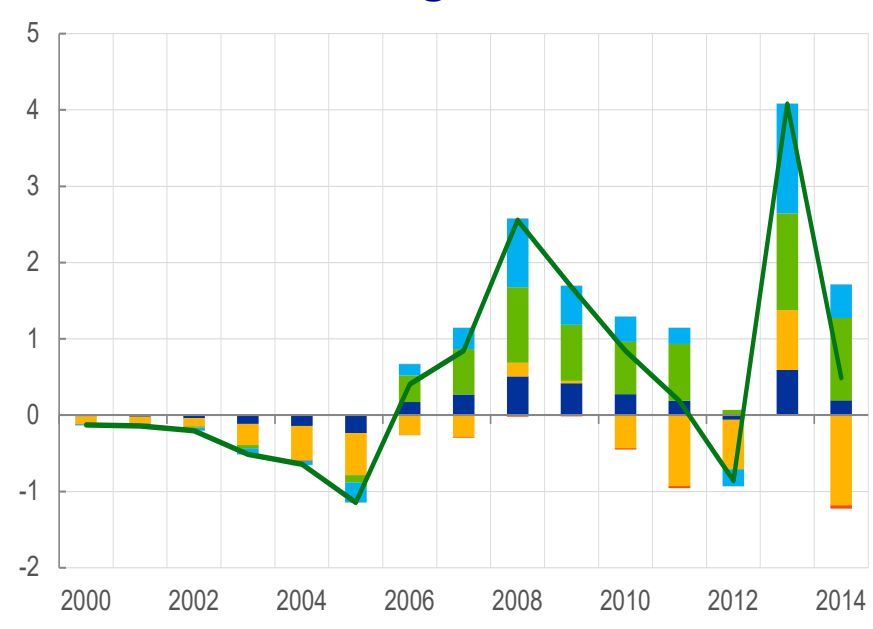

Luxembourg vs. United States

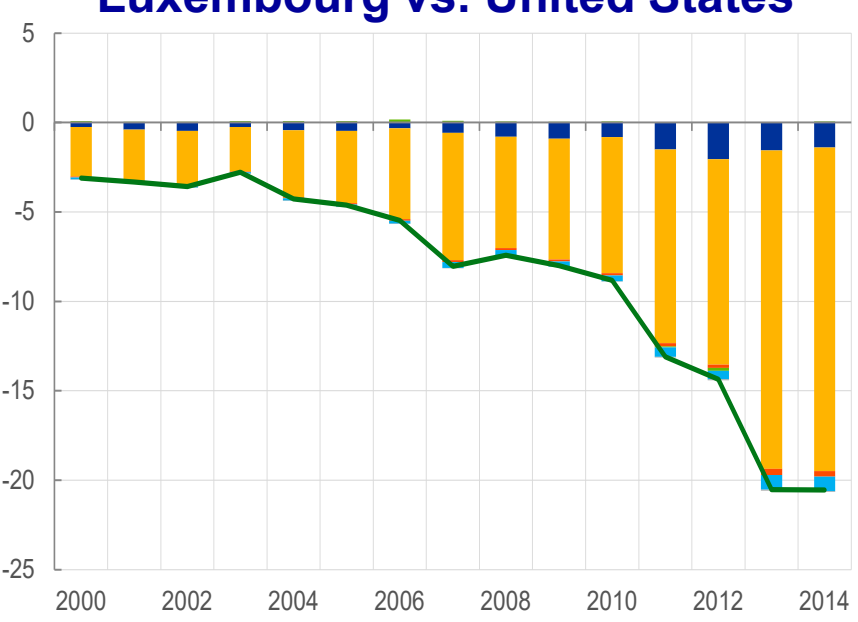

See other economies 


\section{Luxemburg vis à vis the world}

\section{Exports in VA}

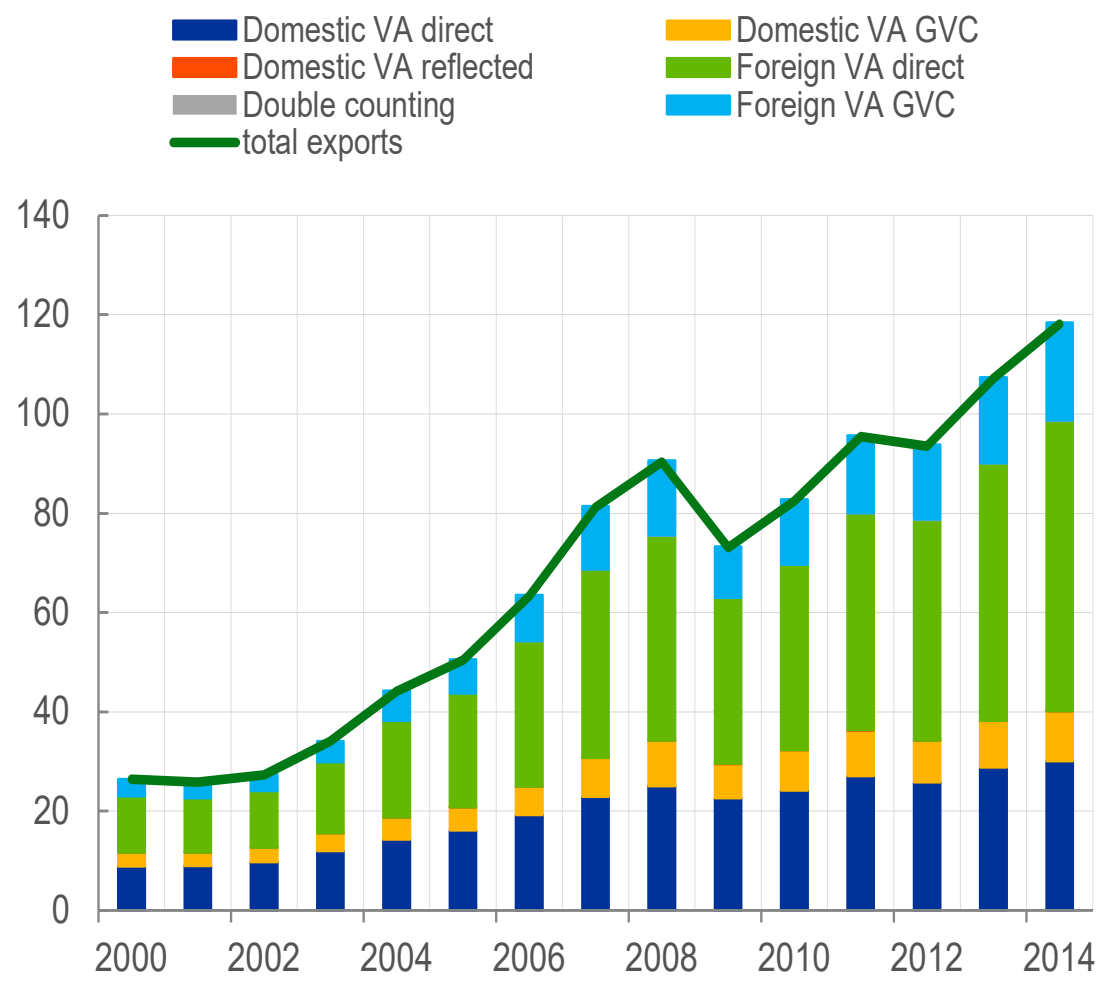

Imports in VA

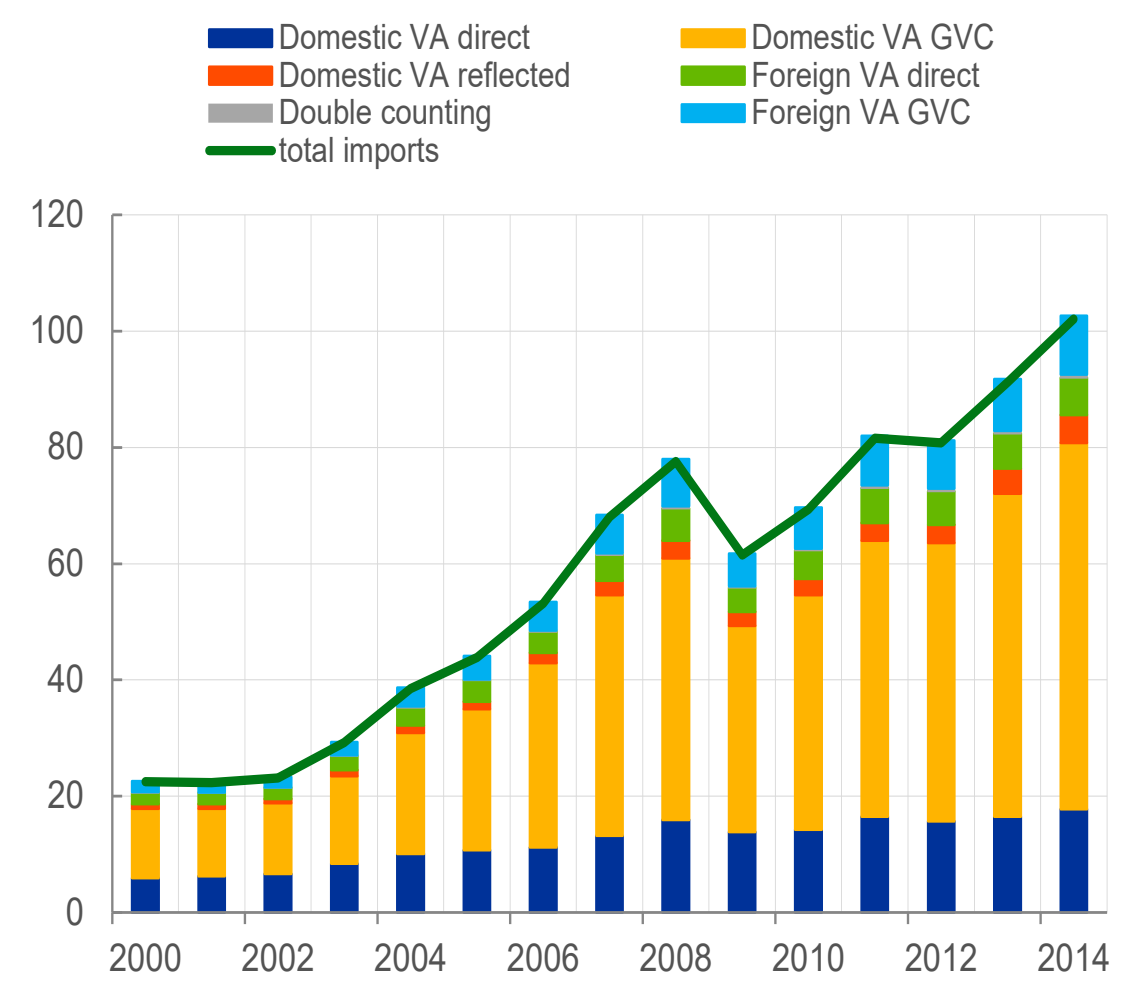

Note: vertical axes expressed in billions USD

Sources: WIOD, authors' calculations 


\section{The VA representation of TB in global economies: large DVADIR}

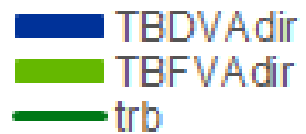

United States

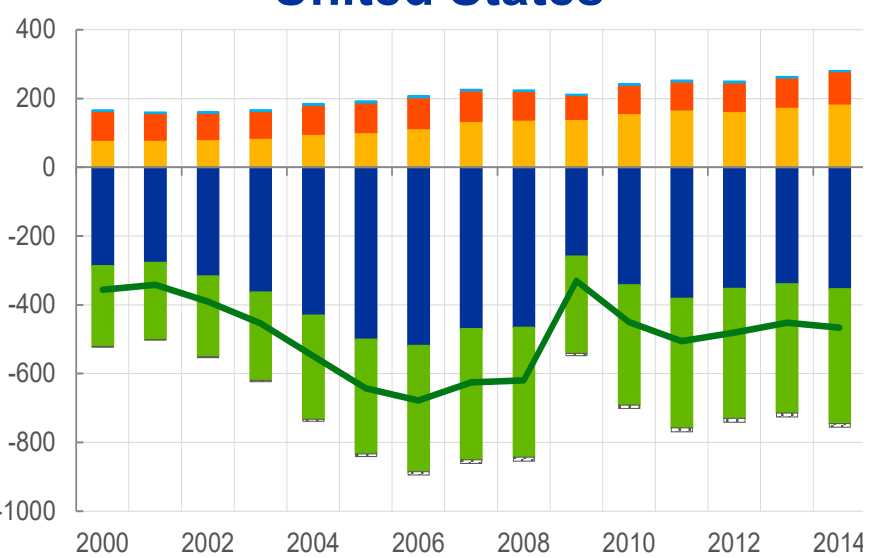

China

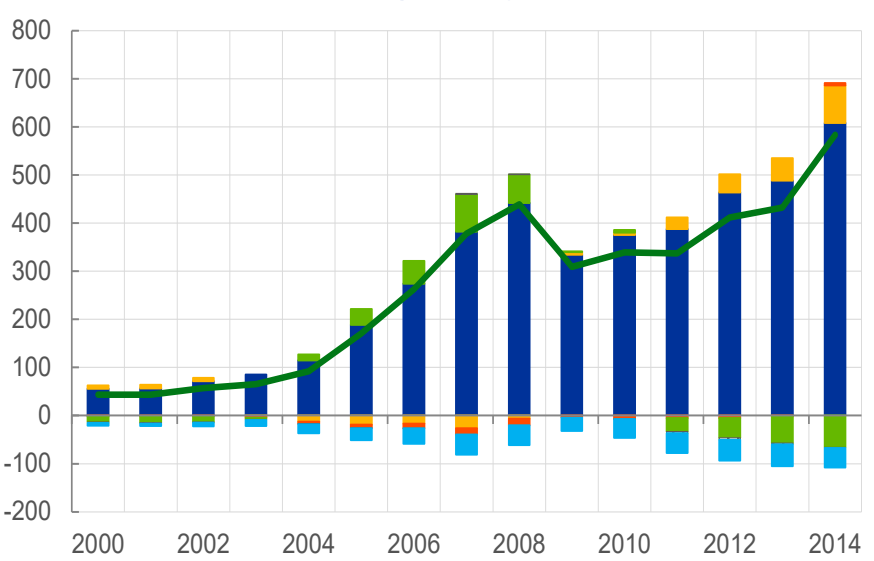

Note: vertical axes expressed in billions USD

Sources: WIOD, authors' calculations
TBDVAGVC mIm TBDCO

TBDVAREF

TBFVAGVC

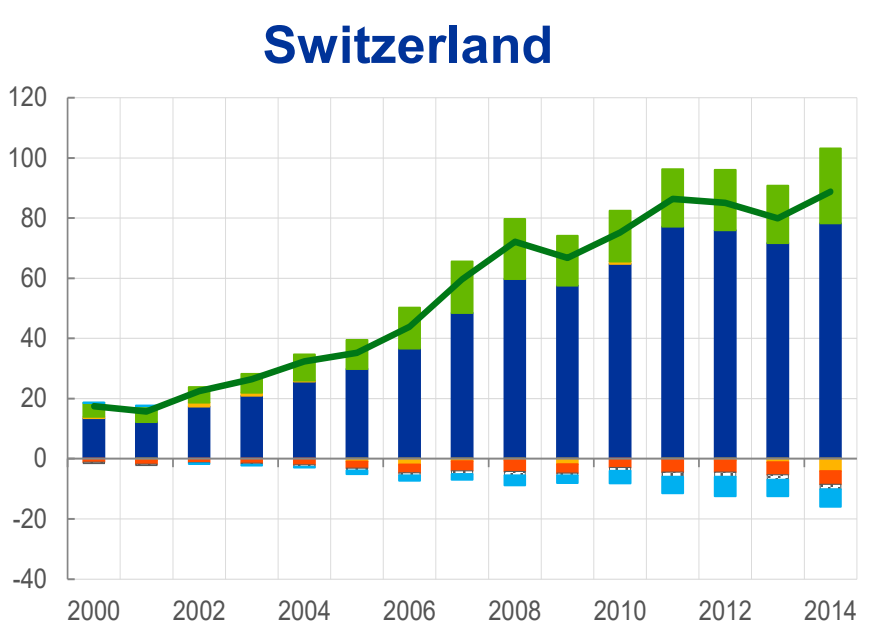

Japan

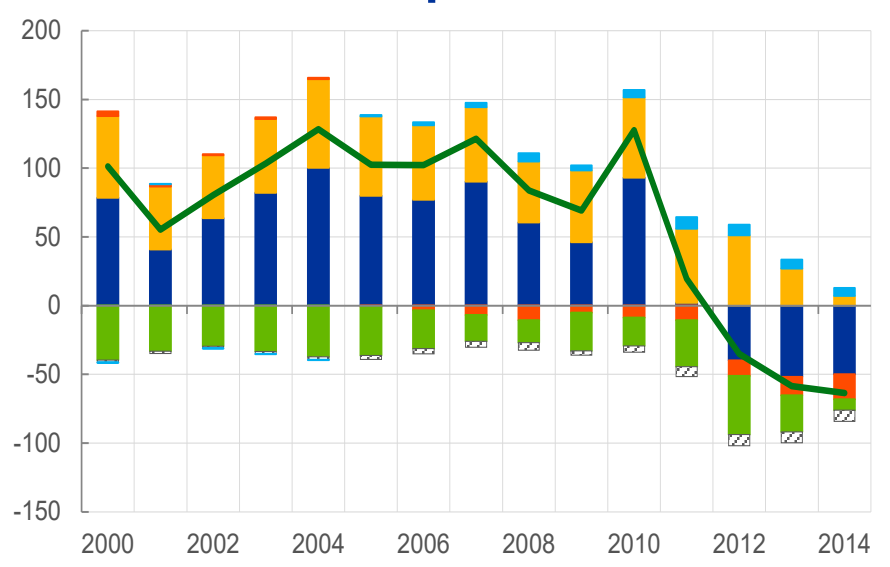

See other economies Definitions 


\section{Decomposing the trade balance in value added}

$\begin{array}{lll}\text { DVAdir } & \text { DVAinGVC } & \text { DVAinREF } \\ \text { FVAdir } & \text { FVAingVC } & \text { DCO } \\ \text { trb } & & \end{array}$

Malta

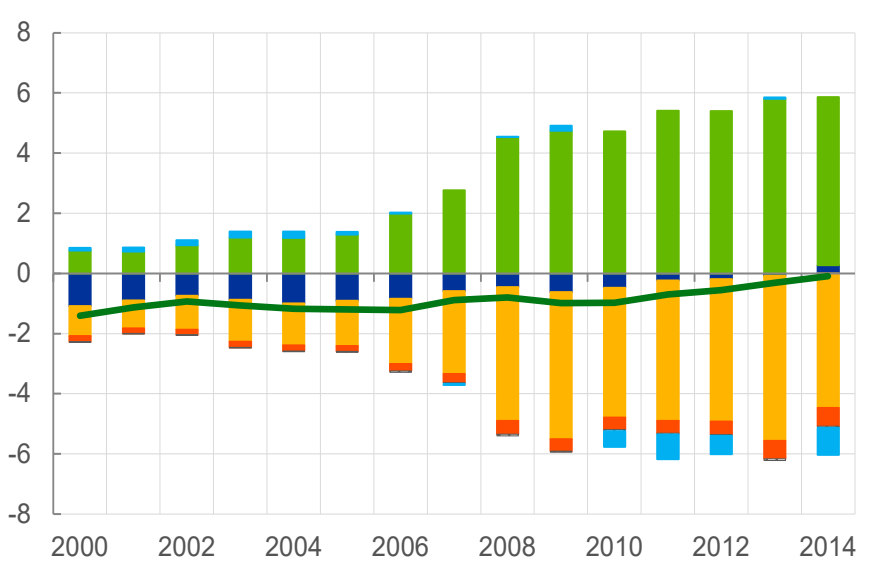

Germany

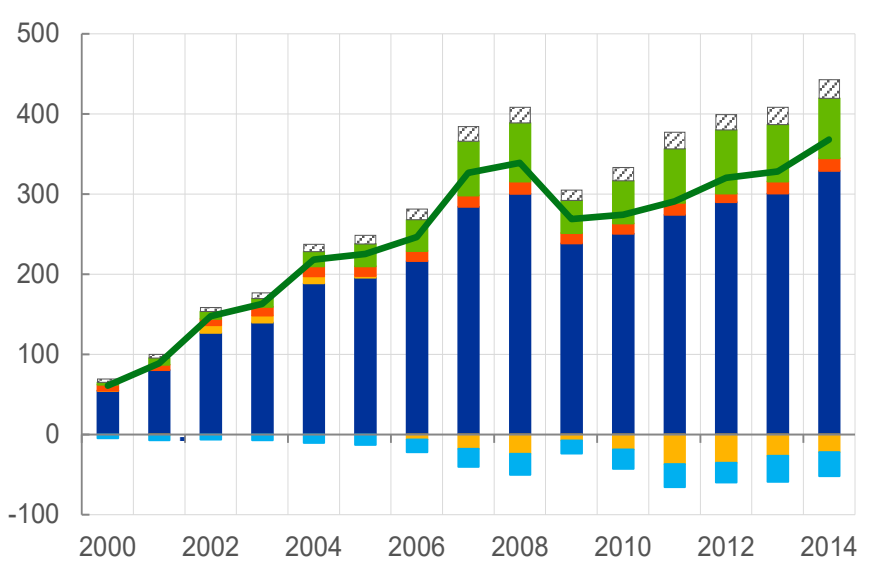

United States

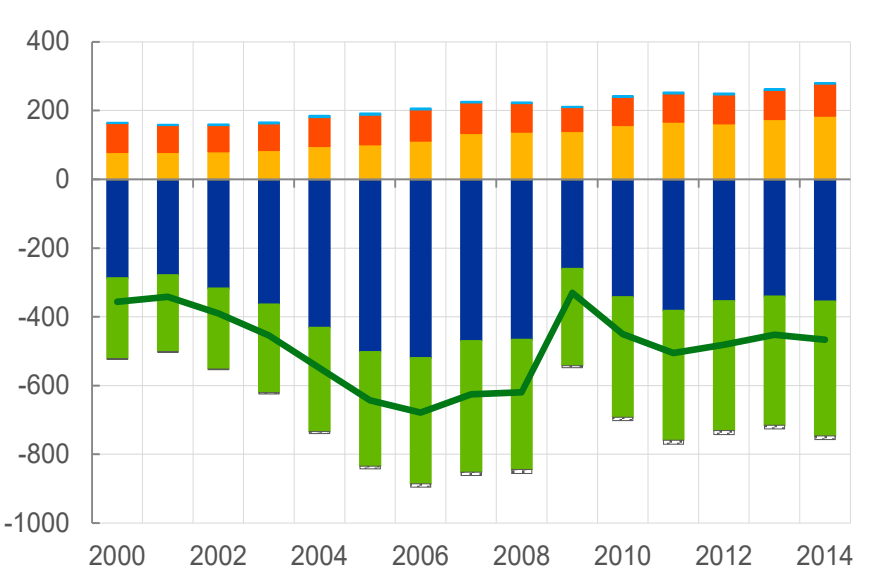

China

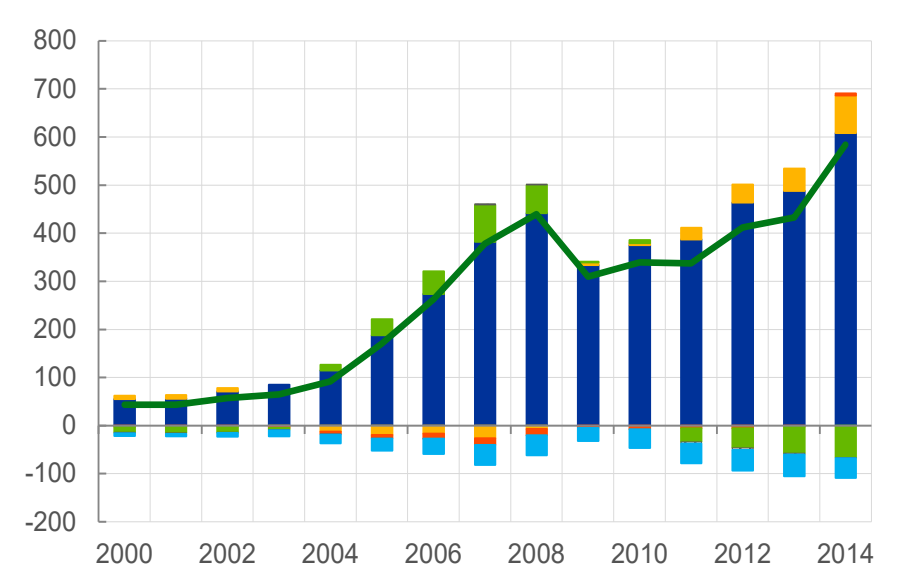


Bilateral Trade Balance in Value added, were FVA ends up

DVAdir

FVAdir

— trb

Ireland vs. Italy

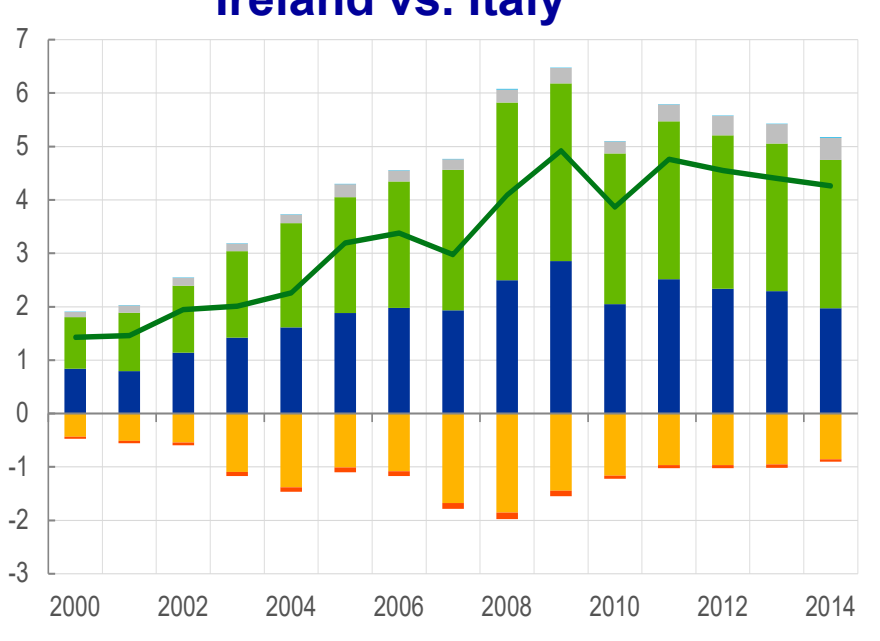

Ireland vs. France

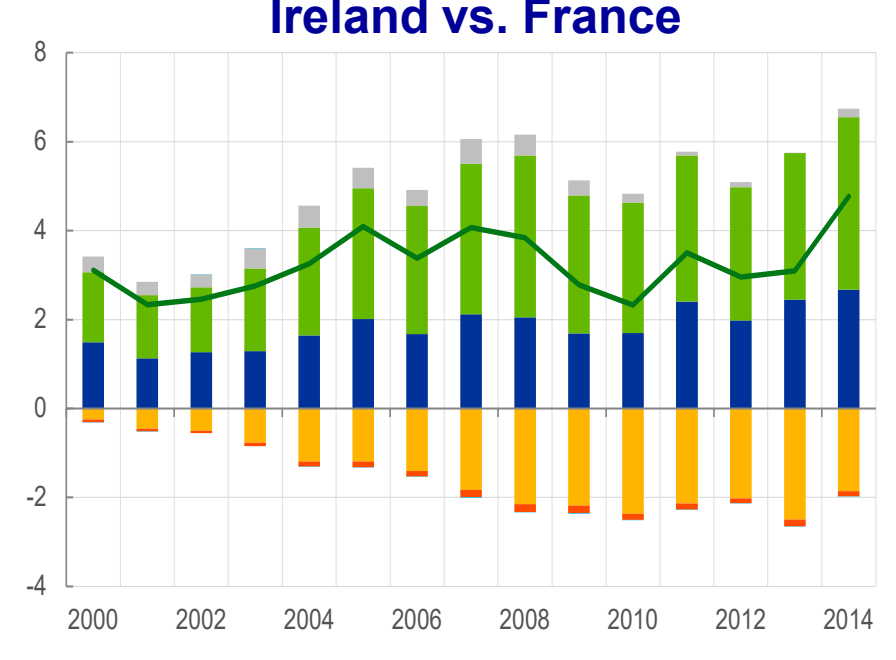

Sources: WIOD, authors' calculations
DVAinGVC

FVAinGVC

DVAinREF

- DCO
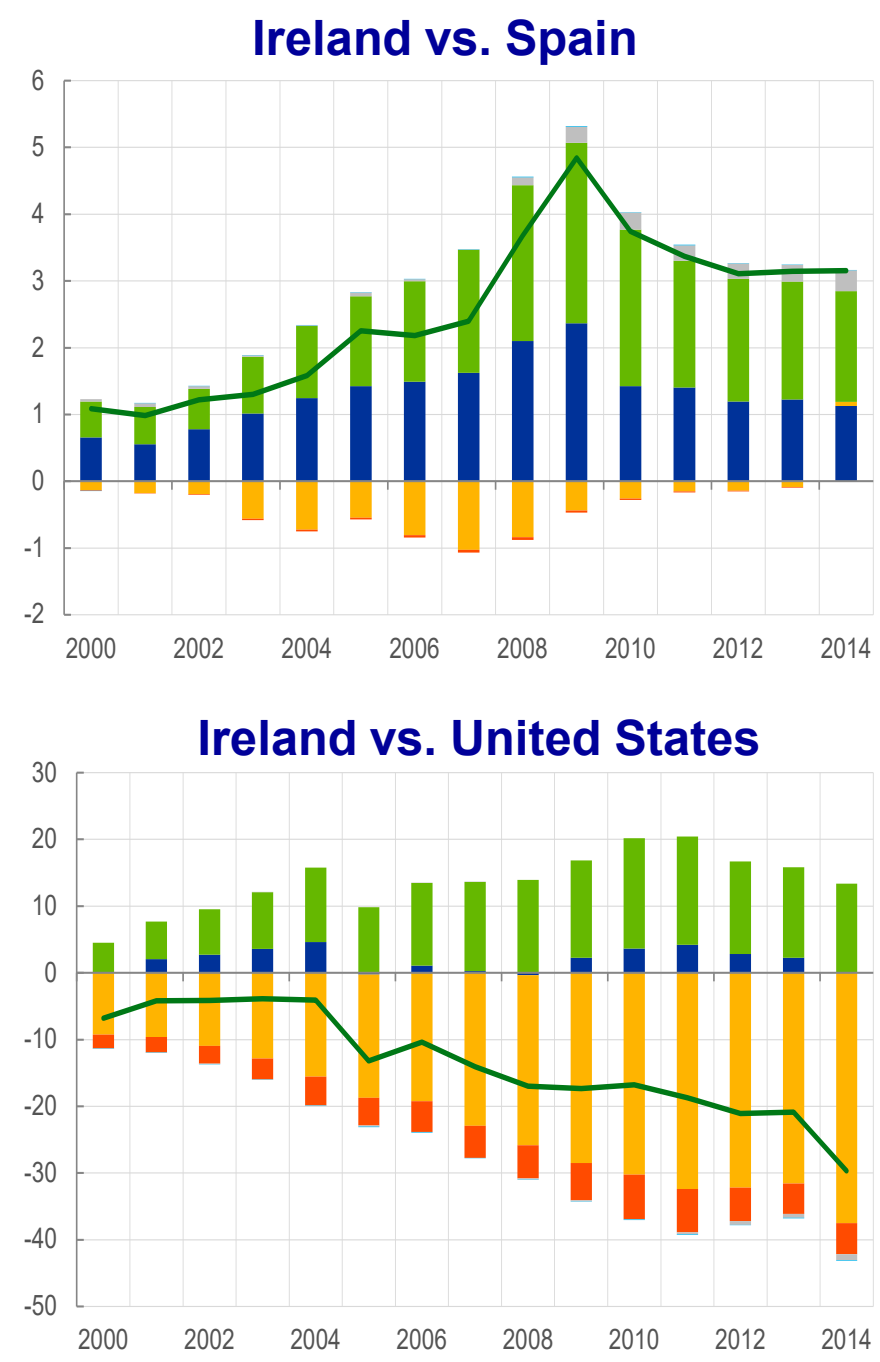
Bilateral Trade Balance in Value added, were FVA ends up

DVAdir

FVAdir

- trb

Belgium vs. Germany

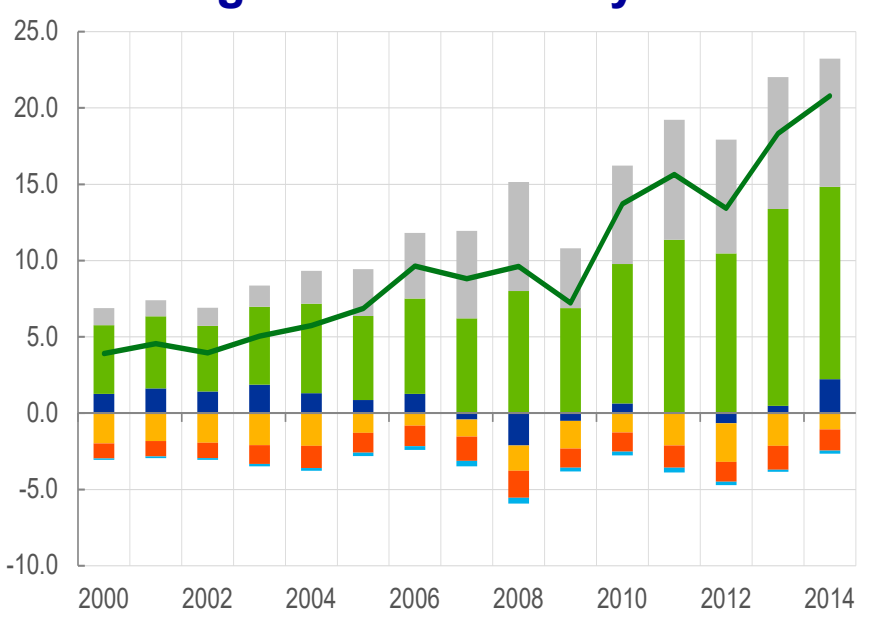

Belgium vs. France

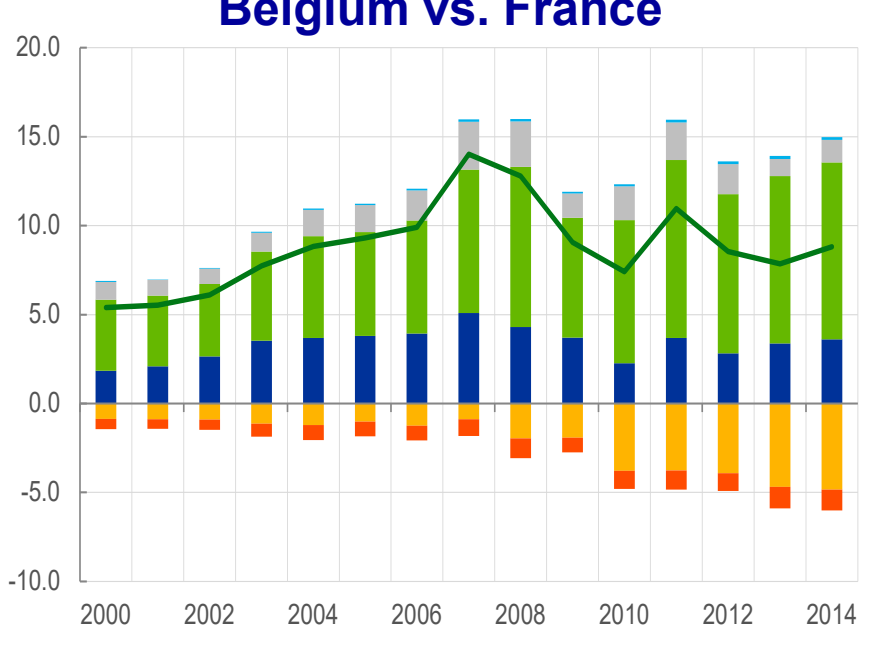

DVAinGVC

FVAinGVC

DVAinREF

DCO
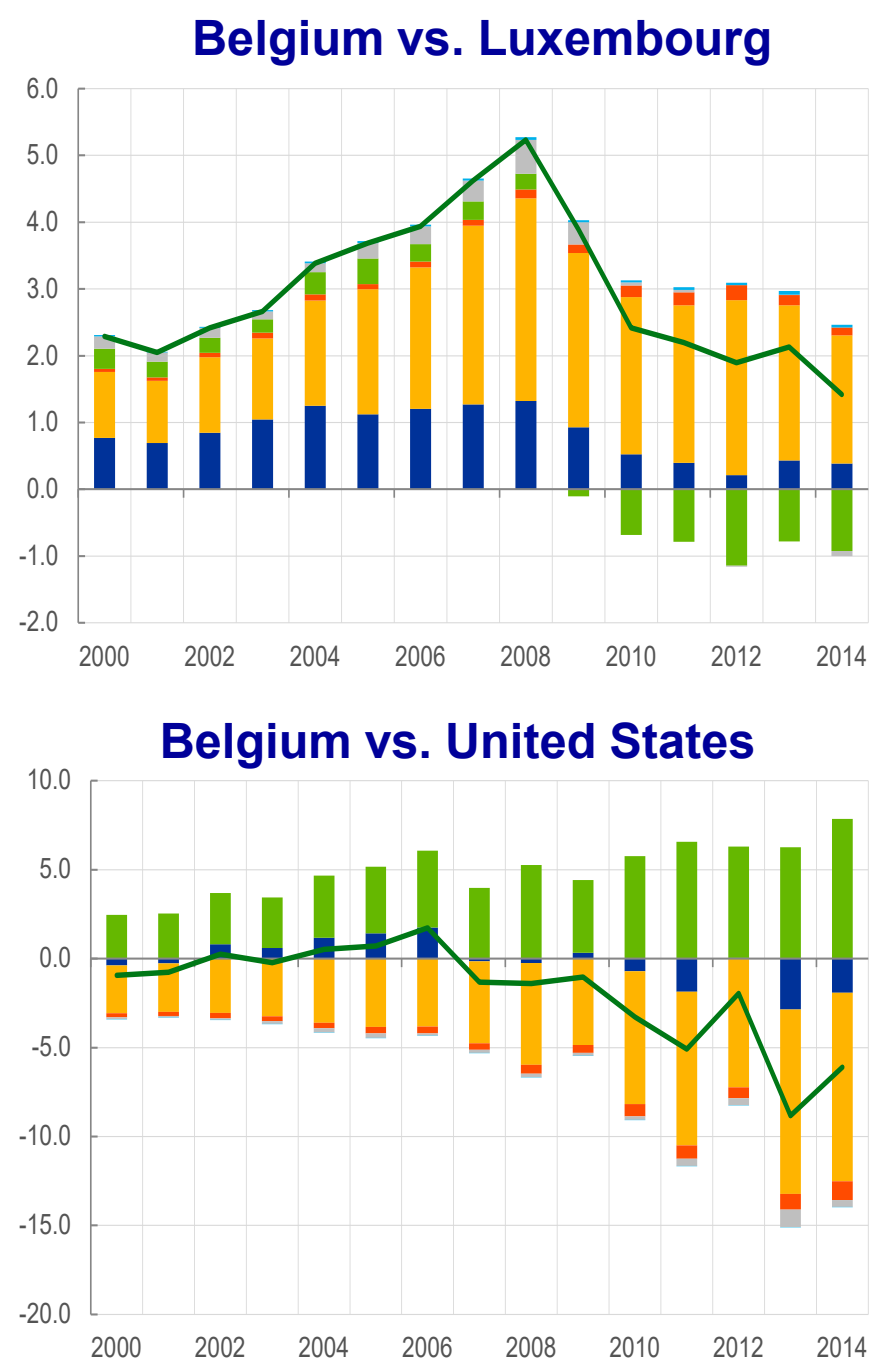

Sources: WIOD, authors' calculations 
Germany vis à vis the world
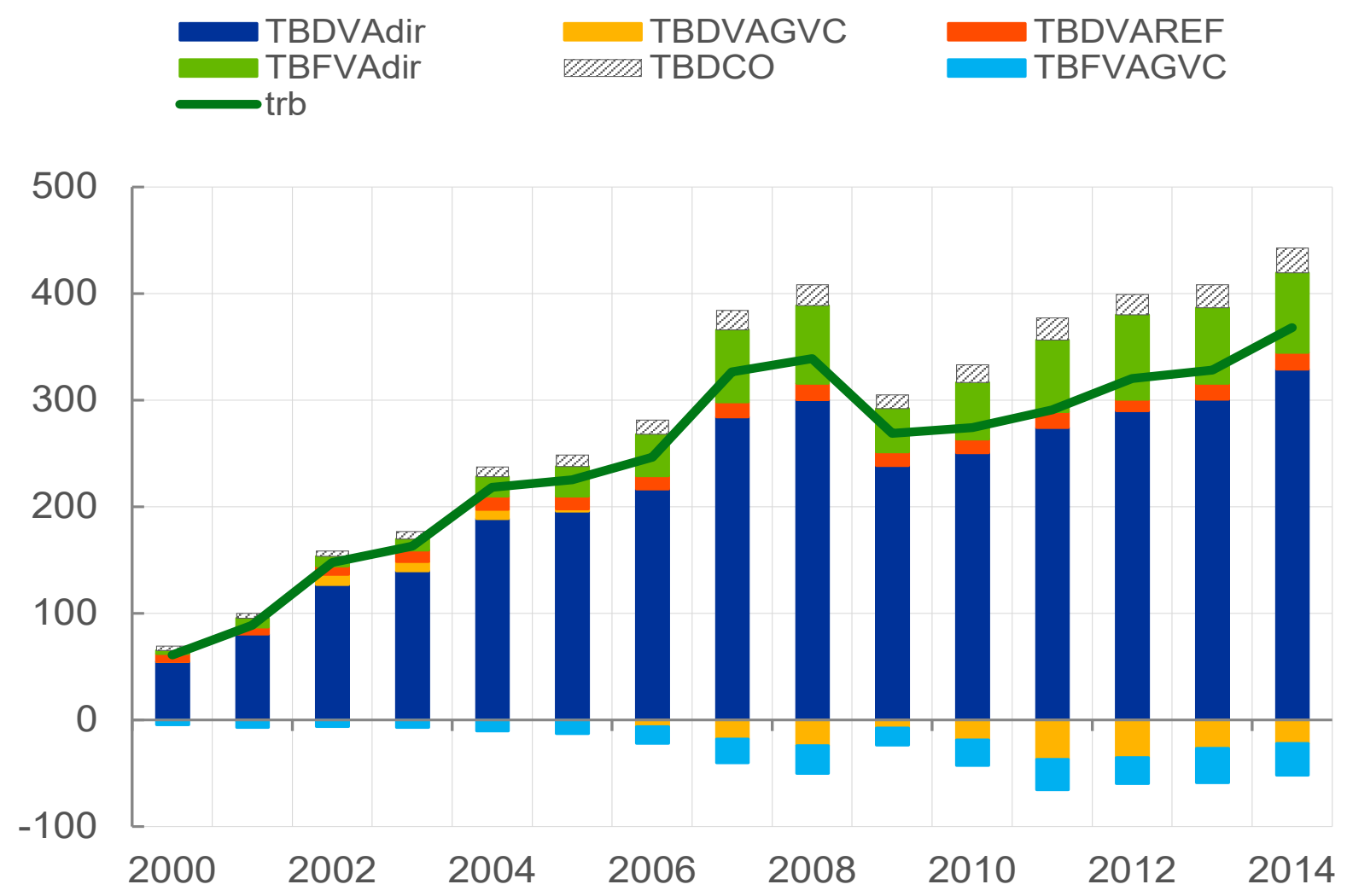

Sources: WIOD, authors' calculations 


\section{Germany vis à vis the world}

\section{Exports in VA}

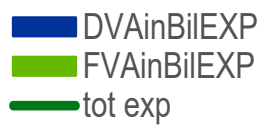

$\begin{array}{rr}\text { DVAinGVCEXP } & \text { DVAinREFEXP } \\ \text { W/HDCOinBilEXP } & \text { FVAinGVCEXP }\end{array}$

$\longrightarrow$ tot $\exp$

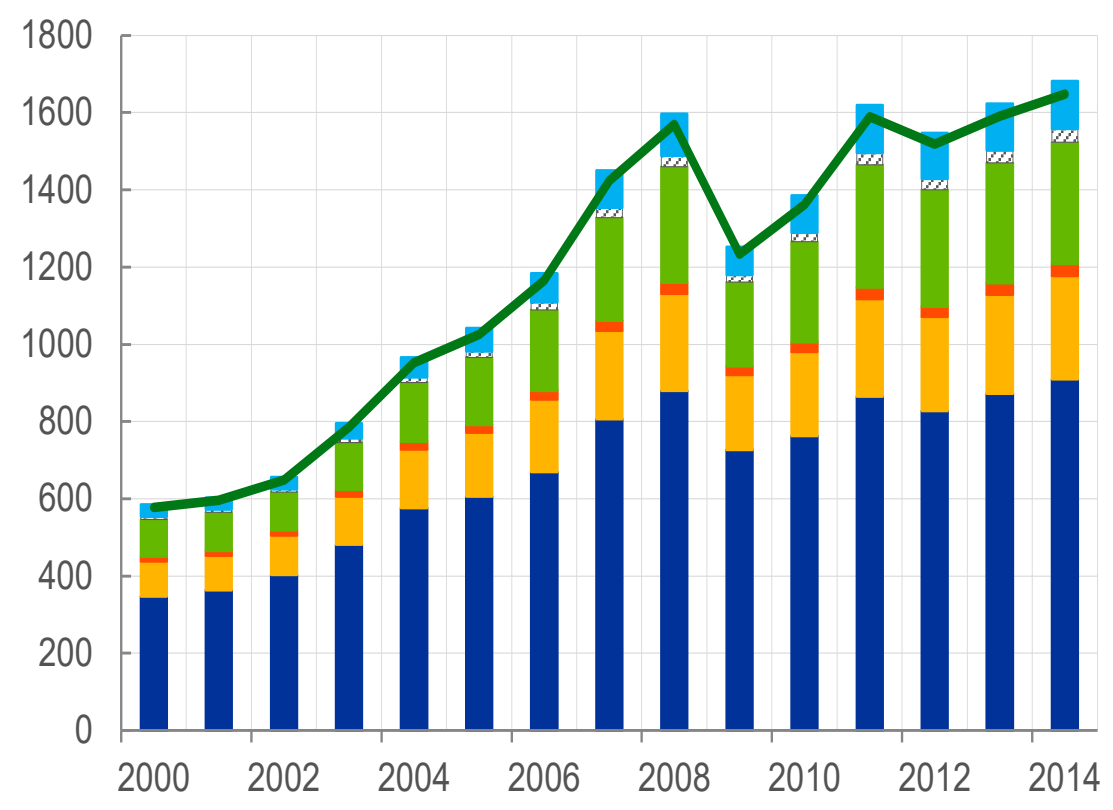

Imports in VA
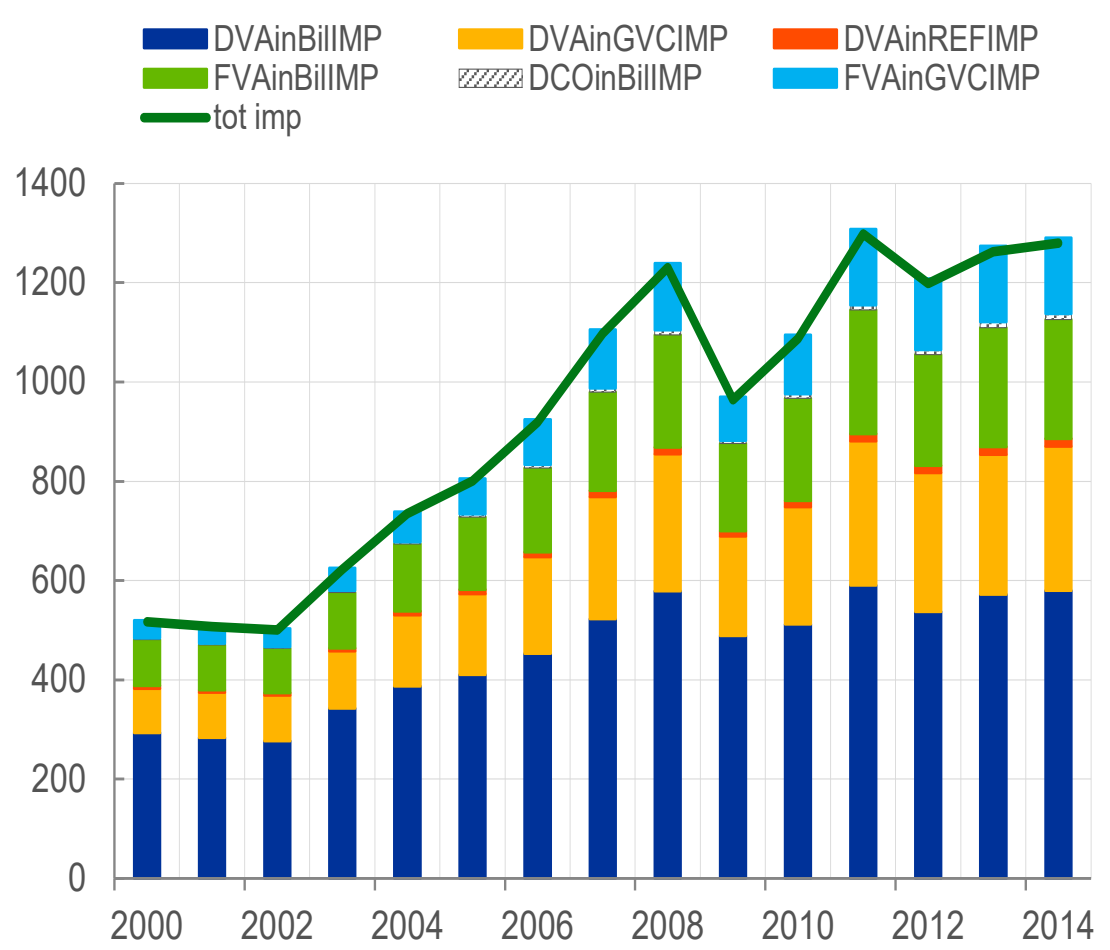

Sources: WIOD, authors' calculations 


\section{Bilateral Trade Balance in Value added, were FVA ends up}

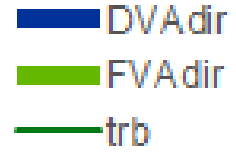

Germany vs. Italy

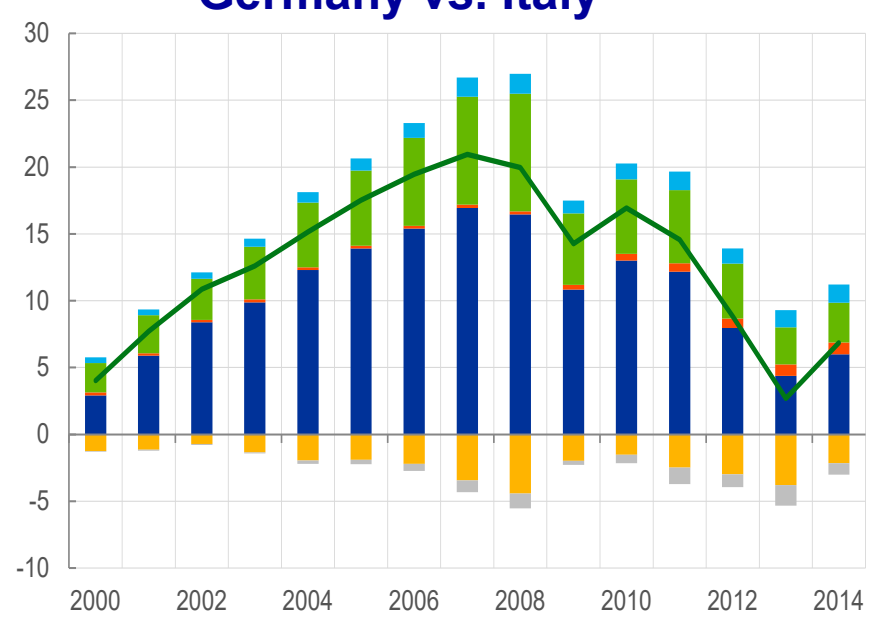

Germany vs. France

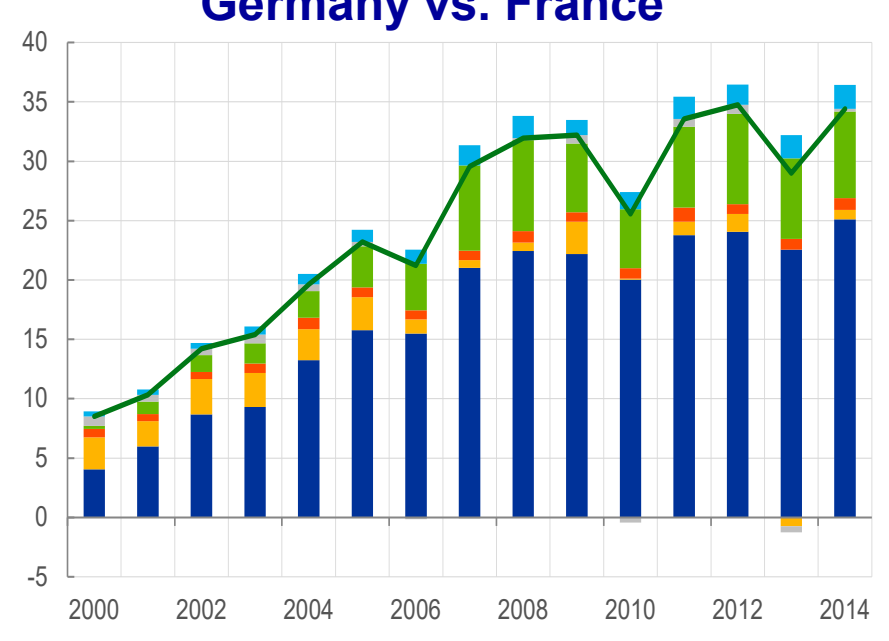

Sources: WIOD, authors' calculations
DVAinGVC

FVAinGVC

DVAinREF

DCO
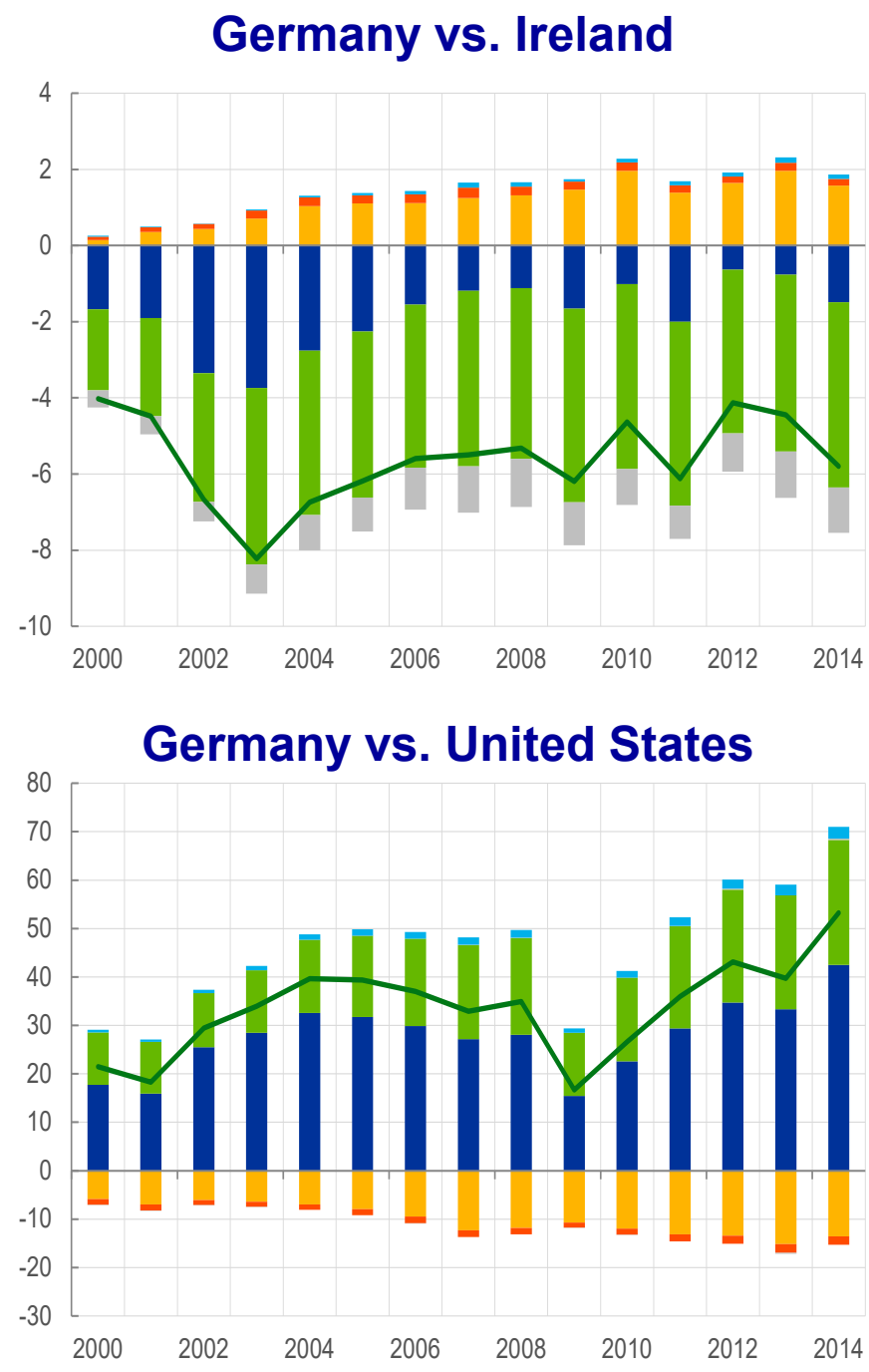

38

See other economies 


\section{Belgium vis à vis the world}
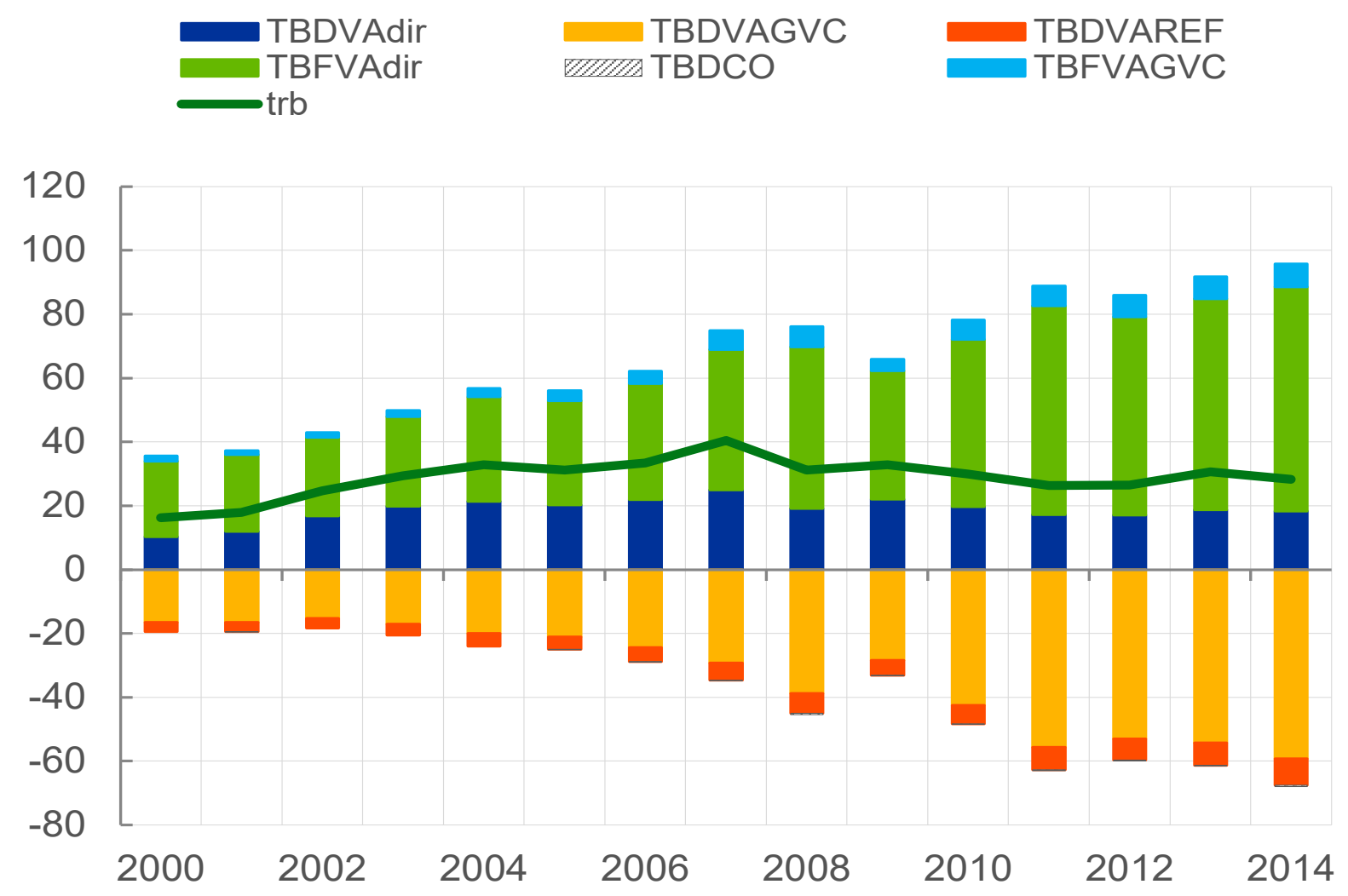

Sources: WIOD, authors' calculations 


\section{Belgium vis à vis the world}

\section{Exports in VA}
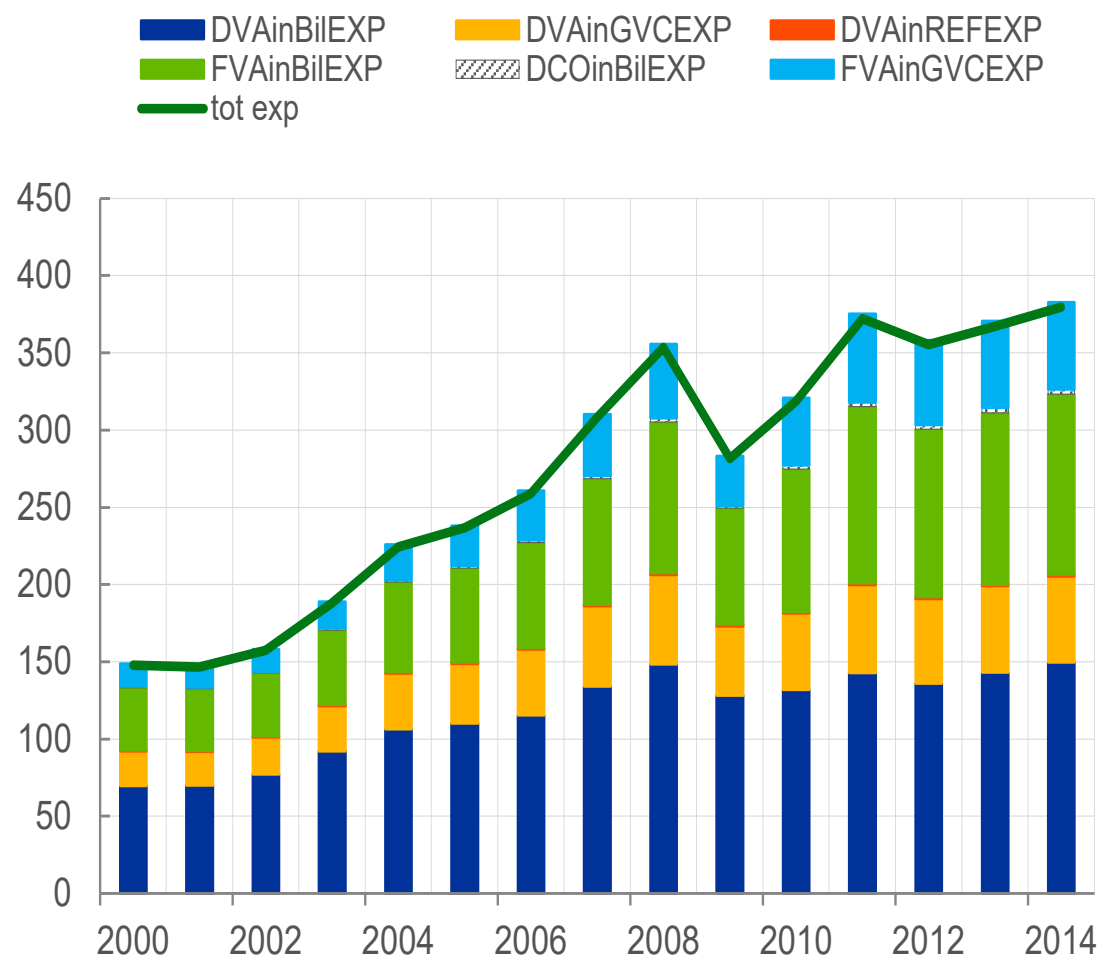

WWODCOinBilEXP

FVAinGVCEXP
Imports in VA

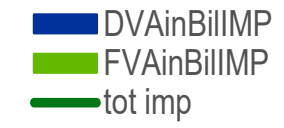

DVAinGVCIMP W/1/DCOinBillMP

DVAinREFIMP FVAinGVCIMP

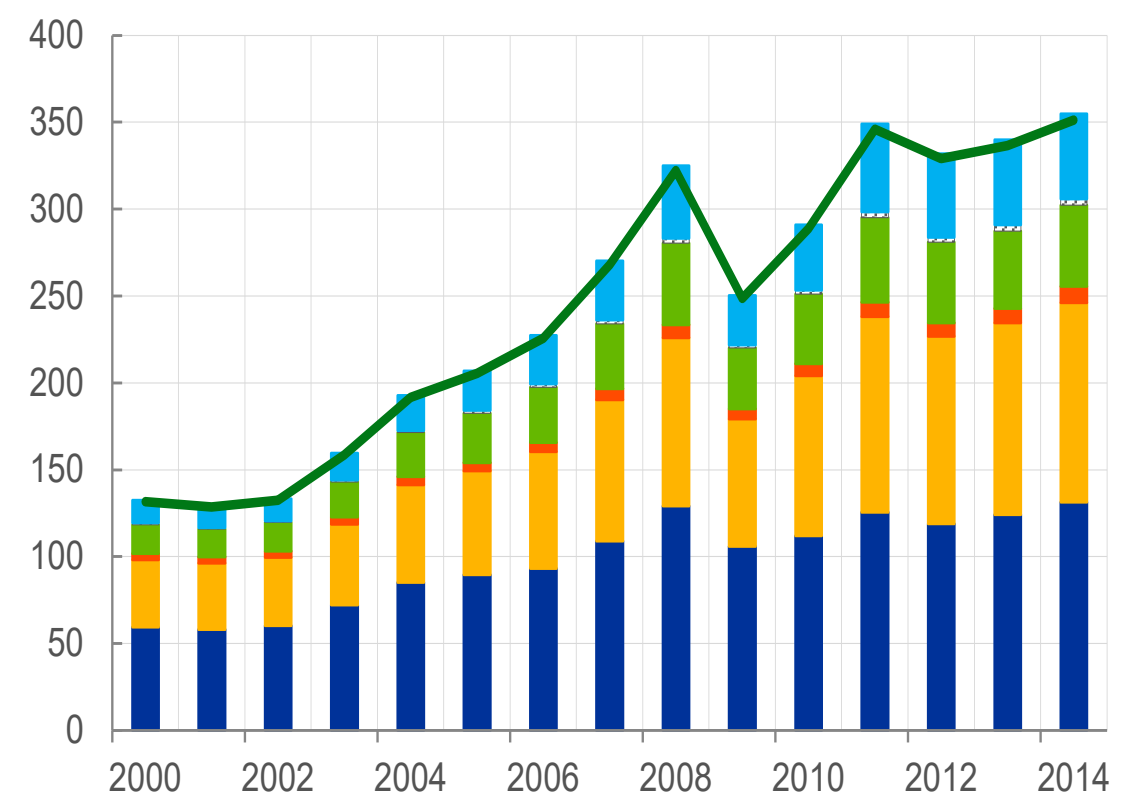

Sources: WIOD, authors' calculations 


\section{Ireland vis à vis the world}
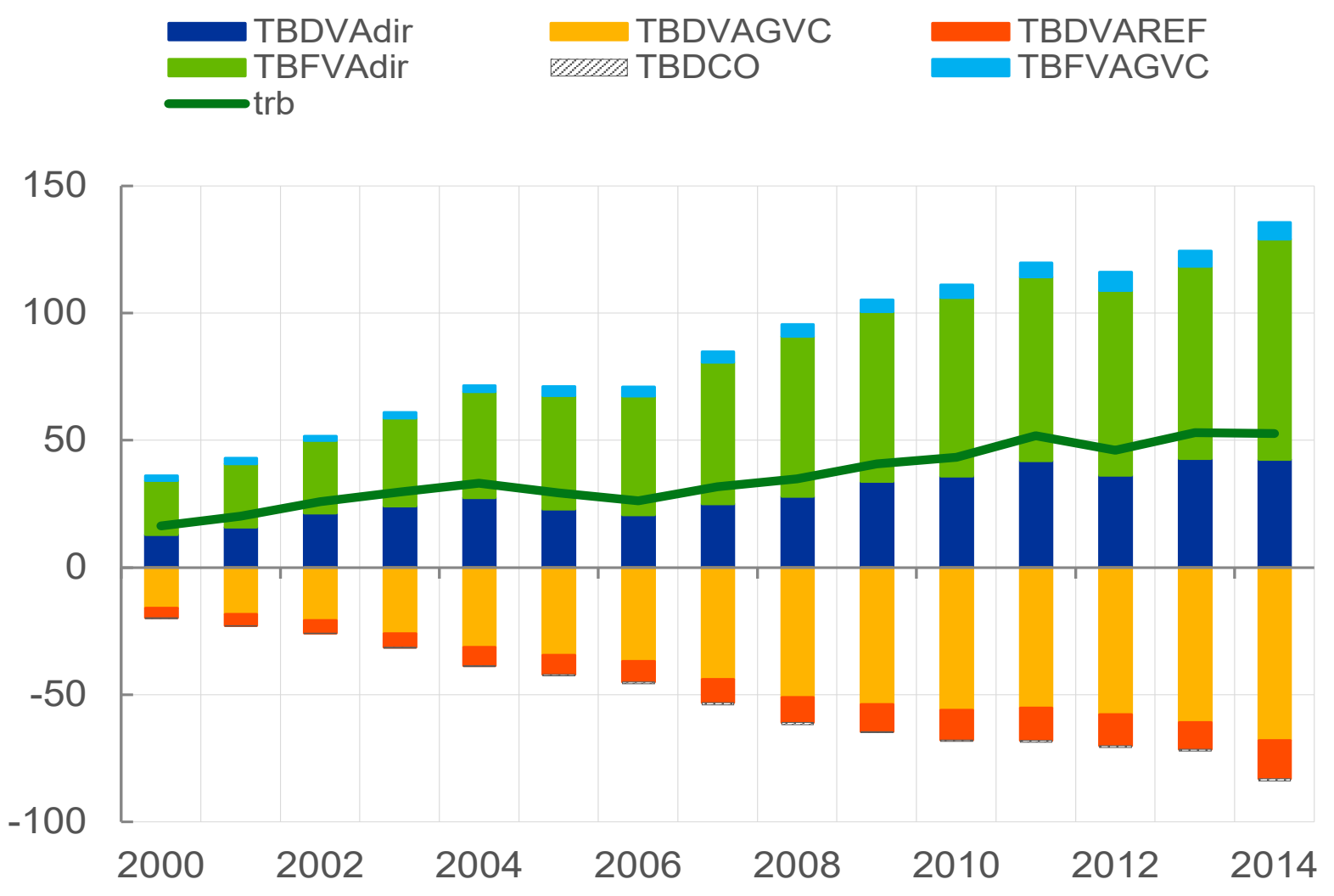

Sources: WIOD, authors' calculations 


\section{Ireland vis à vis the world}

\section{Exports in VA}
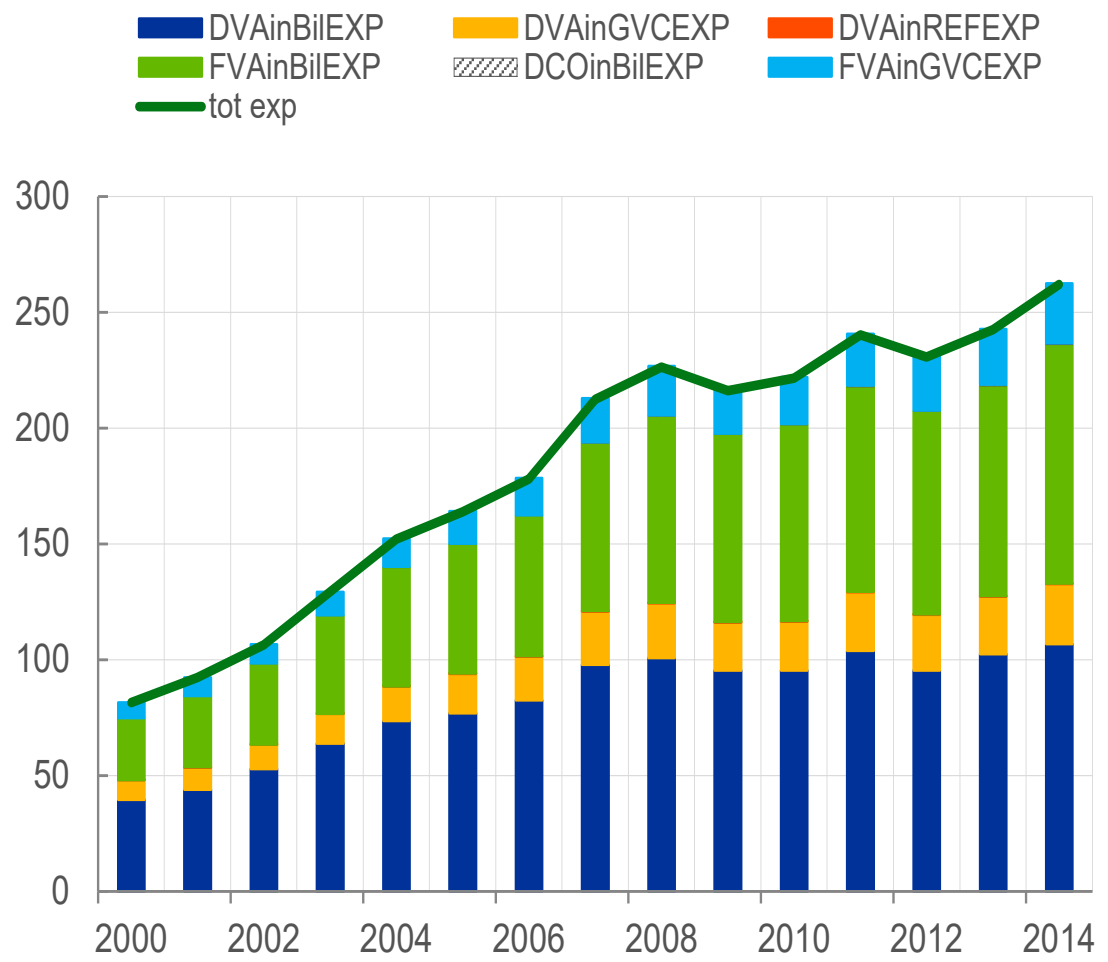

Imports in VA
DVAinBillMP FVAinBillMP - tot imp

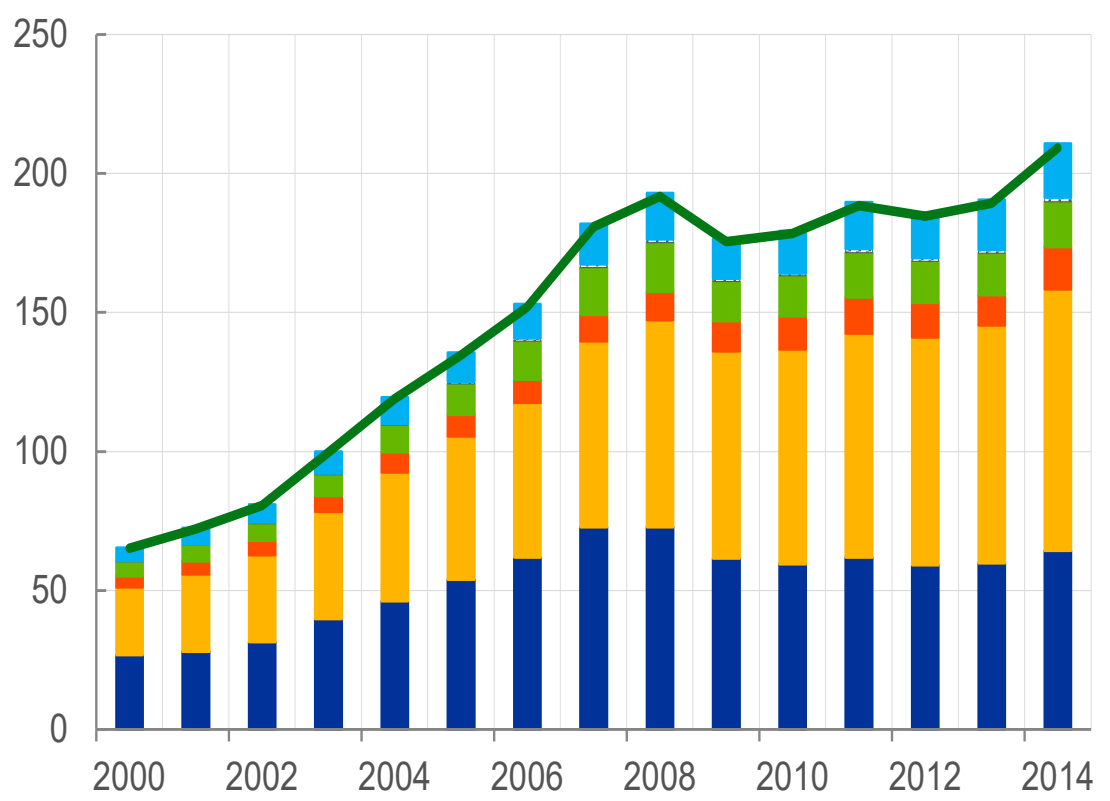

Sources: WIOD, authors' calculations 
The Netherlands vis à vis the world

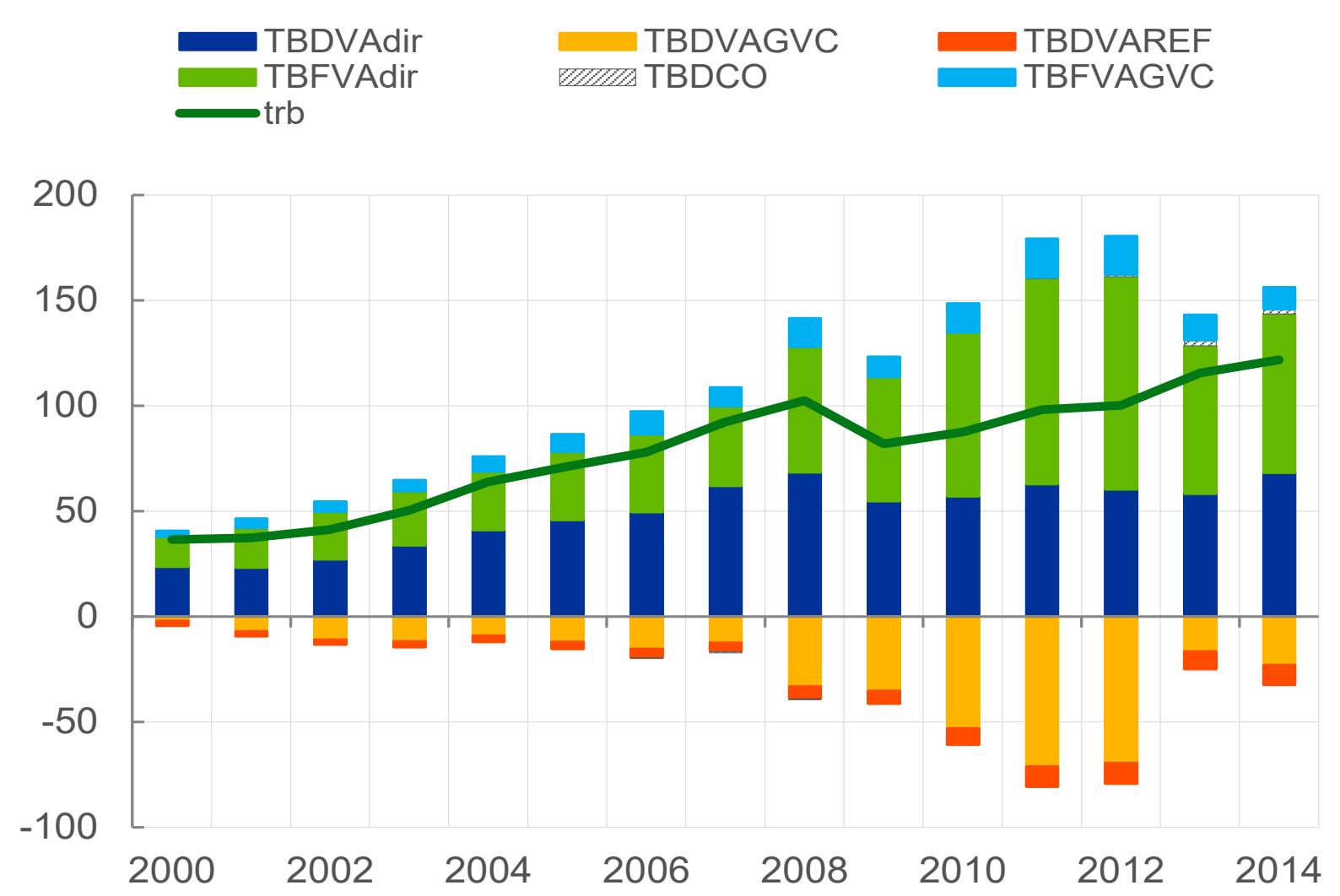

Sources: WIOD, authors' calculations 
The Netherlands vis à vis the world

\section{Exports in VA}
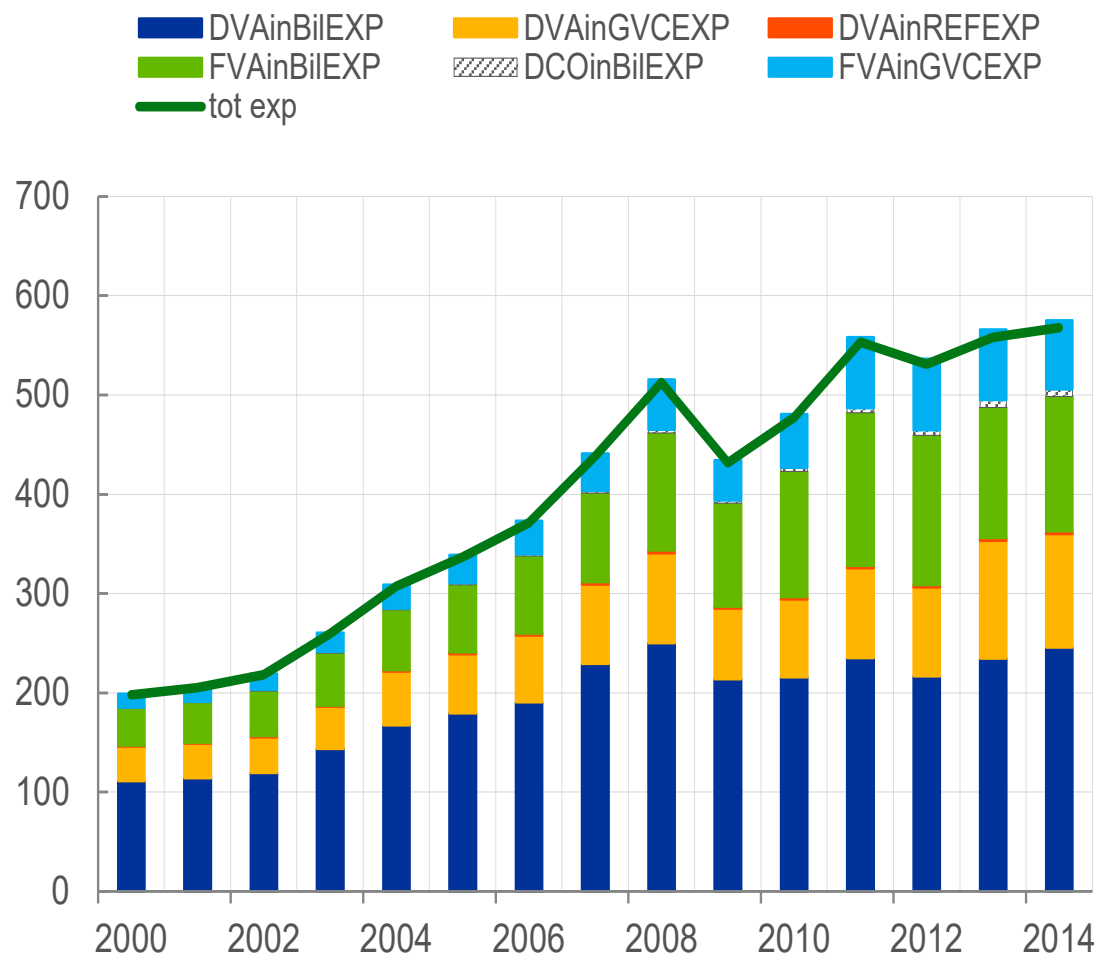

Imports in VA
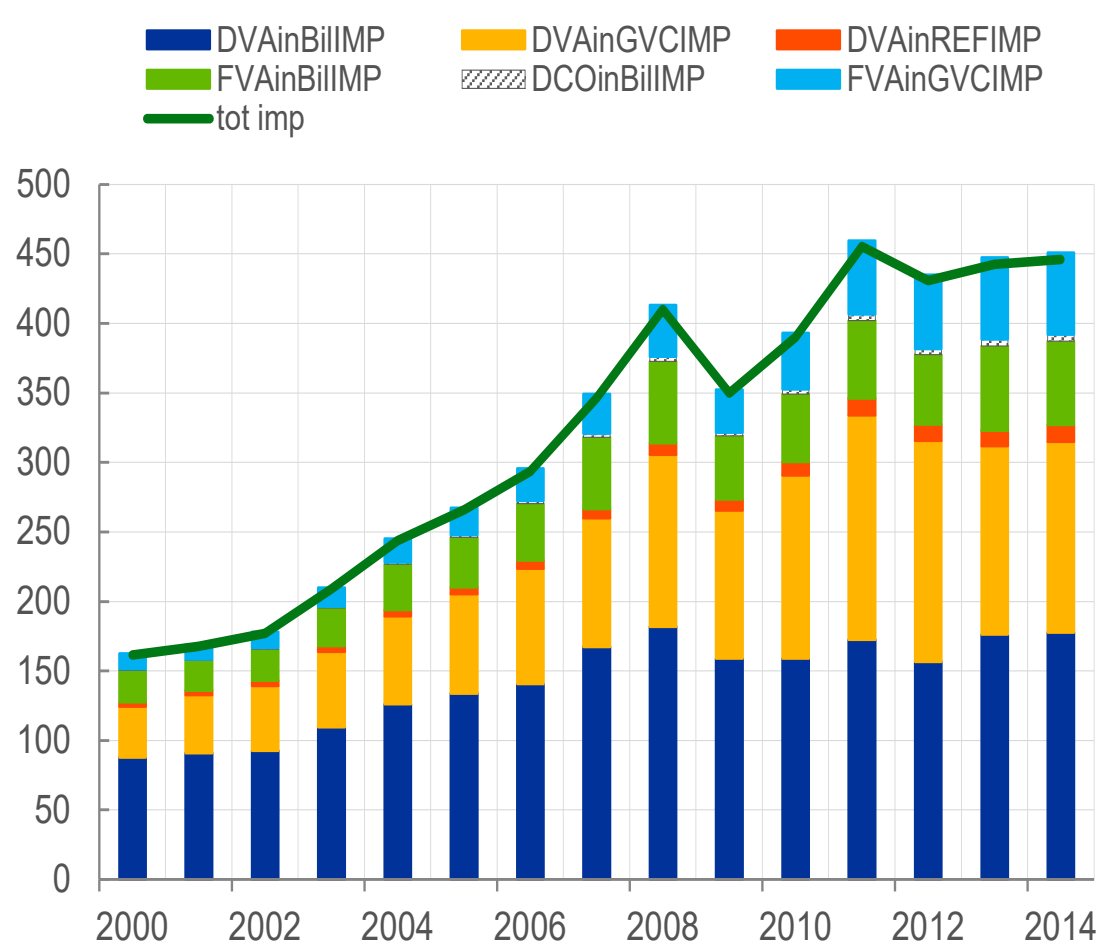

Sources: WIOD, authors' calculations 


\section{Share of exports and imports by VA content by destination in 2014}

\begin{tabular}{|c|c|c|c|c|c|c|c|c|}
\hline & $\begin{array}{c}\text { DVA in } \\
\text { bilateral EXP }\end{array}$ & $\begin{array}{c}\text { DVA in GVC } \\
\text { EXP }\end{array}$ & $\begin{array}{l}\text { DVA } \\
\text { reflected }\end{array}$ & $\begin{array}{c}\text { FVA in } \\
\text { bilateral EXP }\end{array}$ & $\begin{array}{l}\text { FVA in GVC } \\
\text { EXP }\end{array}$ & total DVA & total FVA & Total \\
\hline \multicolumn{9}{|l|}{$4 B$} \\
\hline ROW & 30.3 & 5.3 & 0.2 & 10.5 & 2.2 & 36 & 13 & 49 \\
\hline $\mathrm{EA}$ & 17.2 & 7.8 & 0.8 & 6.4 & 3.8 & 26 & 10 & 36 \\
\hline \multirow[t]{2}{*}{ rest of EU } & 7.8 & 3.0 & 0.4 & 2.8 & 1.4 & 11 & 4 & 15 \\
\hline & 55 & 16 & 1 & 20 & 7 & 73 & 27 & 100 \\
\hline \multicolumn{9}{|l|}{$4 C$} \\
\hline ROW & 18.7 & 3.9 & 0.0 & 14.6 & 3.6 & 23 & 18 & 41 \\
\hline $\mathrm{EA}$ & 15.8 & 9.8 & 0.2 & 11.9 & 7.8 & 26 & 20 & 46 \\
\hline \multirow[t]{3}{*}{ rest of EU } & 5.7 & 1.8 & 0.0 & 4.6 & 1.5 & 7 & 6 & 14 \\
\hline & 40 & 16 & 0 & 31 & 13 & 56 & 44 & 100 \\
\hline & $\begin{array}{c}\text { DVA in } \\
\text { bilateral IMP }\end{array}$ & $\begin{array}{c}\text { DVA in GVC } \\
\text { IMP }\end{array}$ & $\begin{array}{l}\text { DVA } \\
\text { reflected }\end{array}$ & $\begin{array}{c}\text { FVA in } \\
\text { bilateral IMP }\end{array}$ & $\begin{array}{l}\text { FVA in GVC } \\
\text { IMP }\end{array}$ & total DVA & total FVA & Total \\
\hline \multicolumn{9}{|l|}{$4 B$} \\
\hline ROW & 21.8 & 8.7 & 1.0 & 5.6 & 2.7 & 31 & 8 & 40 \\
\hline EA & 20.6 & 8.6 & 0.5 & 10.3 & 5.5 & 30 & 16 & 46 \\
\hline \multirow[t]{2}{*}{ rest of EU } & 6.9 & 3.0 & 0.1 & 3.1 & 1.7 & 10 & 5 & 15 \\
\hline & 49 & 20 & 2 & 19 & 10 & 71 & 29 & 100 \\
\hline \multicolumn{9}{|l|}{$4 C$} \\
\hline ROW & 17.1 & 19.4 & 2.4 & 4.0 & 4.2 & 39 & 8 & 47 \\
\hline EA & 13.0 & 11.7 & 0.9 & 6.0 & 6.4 & 26 & 12 & 38 \\
\hline \multirow[t]{2}{*}{ rest of EU } & 5.2 & 5.8 & 0.4 & 1.7 & 1.7 & 11 & 3 & 15 \\
\hline & 35 & 37 & 4 & 12 & 12 & 76 & 24 & 100 \\
\hline
\end{tabular}

Note: 4B consists of Germany, Italy, France and Spain. 4C consists of Belgium, Ireland, Luxembourg and the Netherlands Sources: WIOD, authors' calculations 